Wh = (17.)

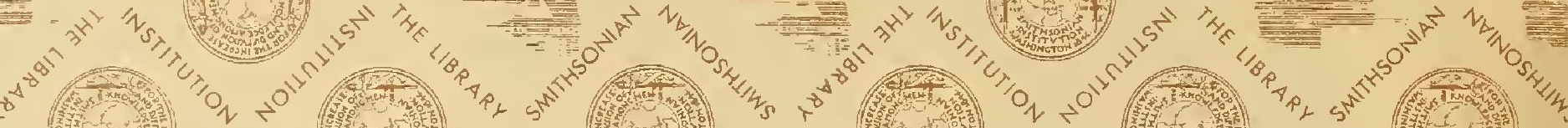

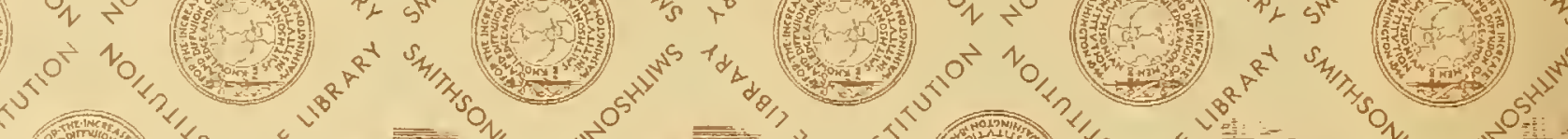
(92)

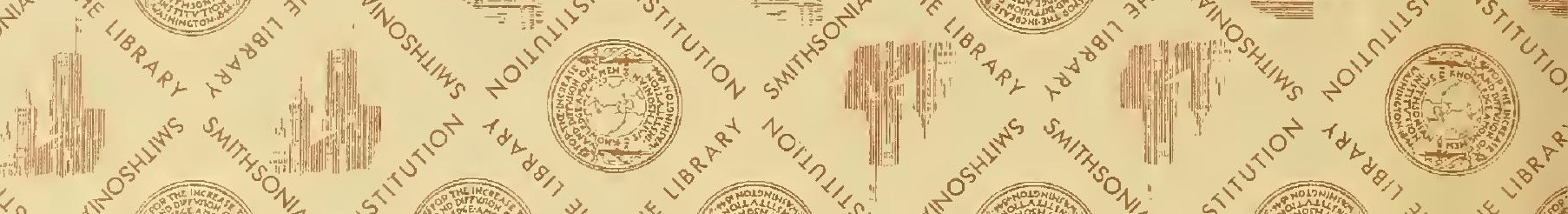
(1) A (2)

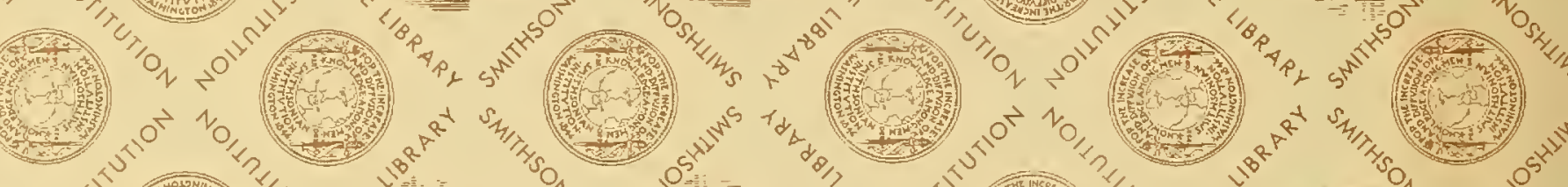
(1) If (7)

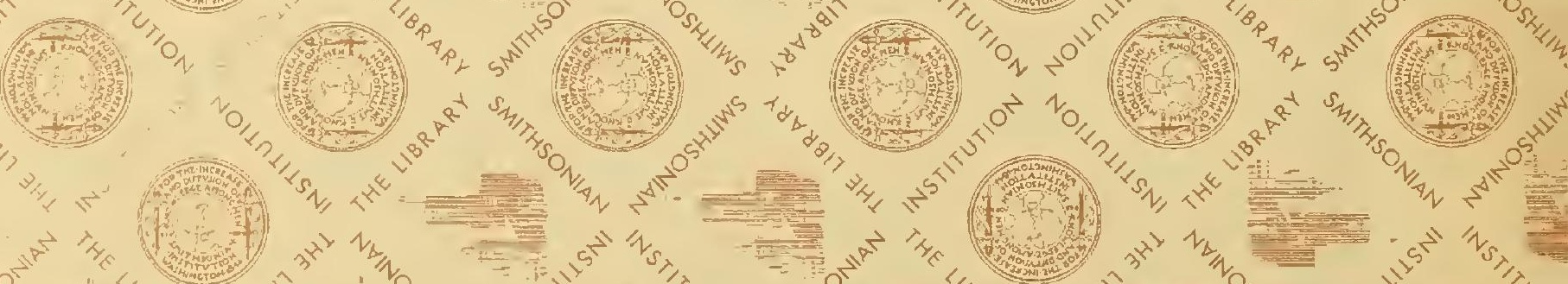




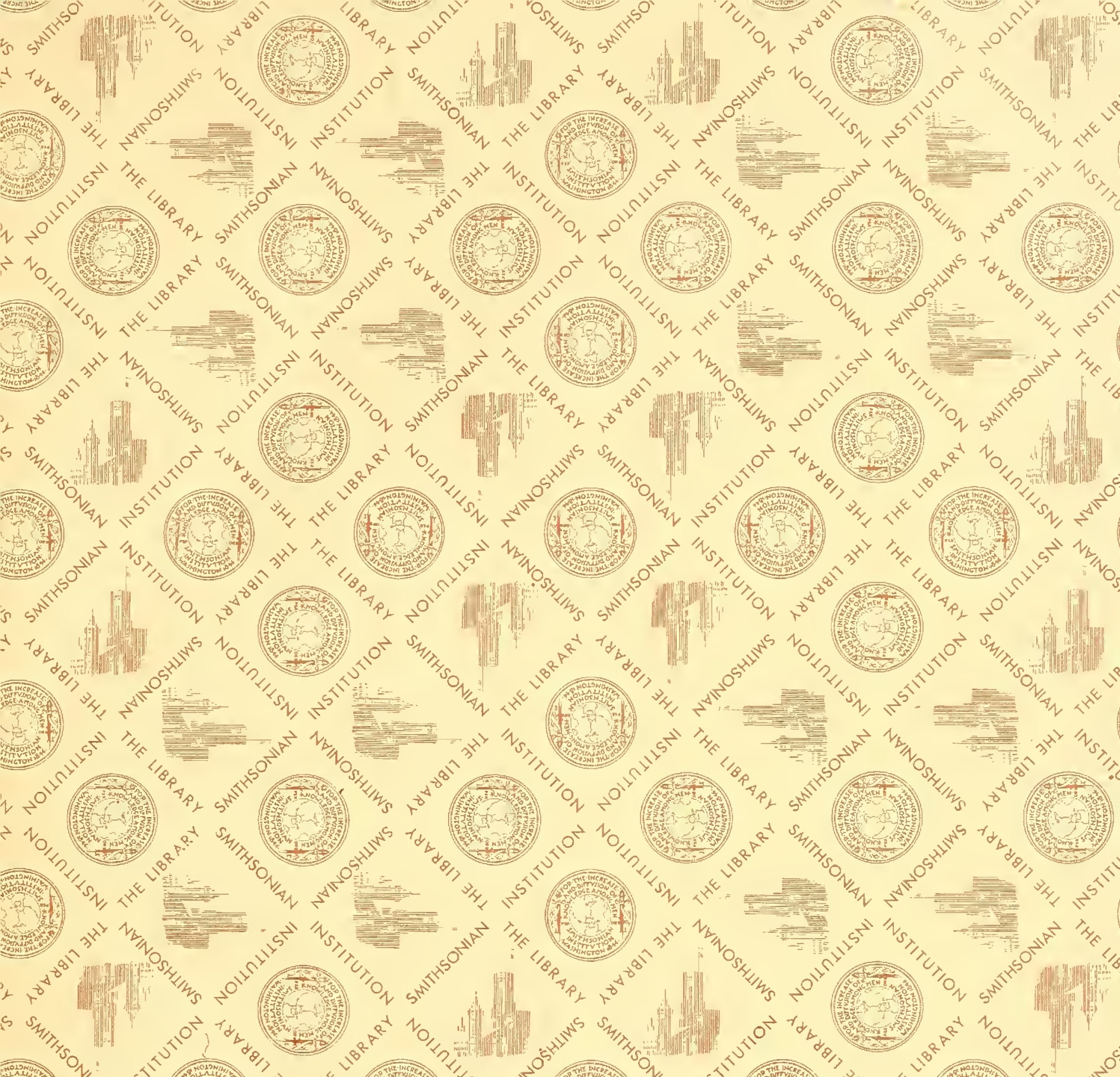







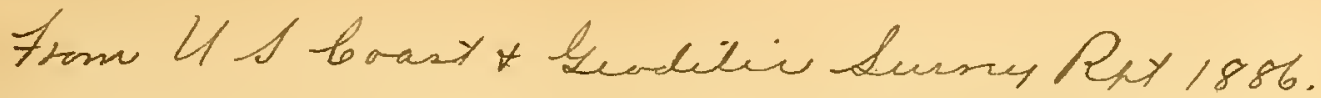

Jec S. Wado,
Wellington, Kaseas

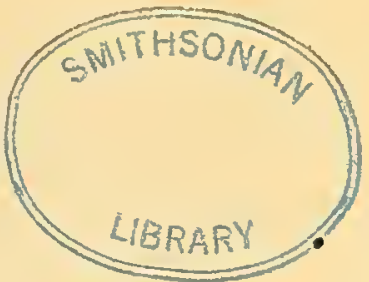

A P P E DIX No. $7-1886$.

\section{AN EXAMINATION OF SOME OF THE EARLY VOYAGES OF DISCOVERY AND EXPLORATION ON TIEE NORTHWEST COAST OF AIIERICA, FROII 1539 TO 1603.}

By Pror; GEORGE DAVIDSON, A. M., Plı.D., Assistant U. S. Coast and Geodetic Surrey.

\section{INTRODUCTION.}

During my work on the Pacific coast of the United States since the spring of $1850 \mathrm{I}$ became deeply interested in the discoveries and explorations of the early Spanish narigators who had folluwed the coast from Cape San Lueas to Alaska. Part of my duty consisted in the determination of the latitude and longitude of the headlands, islands, rocks, harbors, ricers, \&c., and in the geographical reconnaissance of the shores from the Mexican bonndary to the forty-ninth parallel. While in command of the surveying brig R. H. Fauntleros, I entered (in addition to my regular dnties) upon the self.imposed task of writing a Coast Pilot for California, Oregon, and Washington Territory, and I bare nearly completed the fourth edition of that work. Tery natn. rally, my early interest in the old explorations became inteusified, and I made many special examinations of the narratices and their application to supposed localities. I think I hare been able to reconcile mans of the discrepancies of the old Spanish, English, American, and Wrench navigators. Their inaceuracies arose principally from "constant" errors ot their instruments, ignorance of the coast currents, errors of judgment in estimating distances, \&c. Among the Spanish discoverers, the meagerness of detailed descriptions, a failure to seize the salient points for the determining of their positions, the want of minute accuracy in most of their plans-sometimes giving weight to general features and sometimes to details withont distiuction-and a leaning to exaggerate certain discoveries and to completely orerlook others, liave mnch involved the locating of many of their landfalls, headlands, monutains, and streams. The minnteness of reeord in Cook and Vancourer, of comparatively recent date, has enabled me to tollow their tracks day by day and to correet their positions by personal knowledge of the localities described; bnt whilst giving these great men the fullest eredit for survers mparalleled before or since (when all the attendant circumstances are considered), I cannot withlıold $\mathrm{my}$ admiration for the indomita. ble eourage and perseverance of the old Spanish nlarigators, who, in small, ill-conditioned, and illsupplied ressels, with crews neariy destroyed by scurvy, fought their way to the wildest parts of the Alaskan coast almost regardless of season. "There were giants in the earth in those days."

The recorts of such of these voyages as are published are too short to be of mueh more ralue than isolated statements of what was done; and the inaccuracy of the observations for the determination of the geographical positions has led many to judge that all were tonched with the spirit of Maldonado, de Fonte, and de Fnea. But with the present knowledge of our coast it is possible to locate Ulloa; to track Cabrillo and Ferrelo in their diseoreries in mid-winter; to place Drake under Cape Ferrelo and Point Reses, and to fix mith certainty the most of Vizcaino's positions. Later than 1303 I have not undertaken identification in this paper, except to incidentalls mention Father Taraval's risit to Point Engeuio, and his landing upou Natividad and Cerros 
Islands. I was particnlarly interested in the voyages of Cabrillo aud Ferrelo, and I hare endearored to put myself in their places; and nnderstanding the seasons and the difficulties they encountered, I have tried to follow them day by day in their exciting discoveries.

I hare based $\mathrm{my}$ varrative of Cabrillo mpon the condensed and nnsatisfying chaptes in Herrera (B), and have corrected several mistakes and deciphered one or $\mathbf{t}$ wo obscure passages.

Of the narrative supposed to embrace the whole rojage of Cabrillo and Ferrelo, I have freely used the translation made by Mr. Richard Stuart Lvans as printed with introductory remarks by Mr. H. W. Henshaw (H), but in eritical passages where important issues were involred I have examined the original $(\mathrm{C})$ and made my own translations.

Of the royage of Ulloa, I hare had recourse to the short narrative given in Burney aud trauslaterl from (A).

Of the royage by Drake, I have eollated from the "English Hero" (D), and the "World. Encompassed" (E), with reference to the Portus Noræ Albionis in the margin of Hondius' map; and to this map I lave rednced the Coast Survey chart of the ricinity of Drake's Bay to correspond in scale and in orientation, whereby $\mathrm{I}$ have identified his bay.

In the royage of Vizcaino I first trusted to the English translation of Venegas' narrative, bnt I found it so uncertain in critieal positions that I had reconrse to the original ( $F$ ); and I hare used Tizeaino's chart of the coast exhibited in Burney, Part II of his series of volnmes of Voyages and Diseoveries (G).

For details of some of the points and anchorages sonth of Todos Santos Bay I have used the Coast Survey eharts of 1874 and the descriptions of the "West Coast of Mexico, from the Northern Boundary," published by the Hydrographic Bureau of the United States Nary (I).

To preserve aceuracy and eonsistency of deseription on the eoast north of Mexico, I hare referred to the manuscript of the fourth edition of the "Coast Pilot of California, Oregon, aut Washington" (J), and constantly to the eharts of the United States Coast and Geodetic Survey.

Tlie full titles of these anthorities are appended to this introduction with the reference letters.

In order to present as clearly as practicable the deseriptions of localities by the different uavigators, I have drawn them up in three parallel columns, preserving in the case of Cabrillo and Ferrelo the whole of their narratives. My notes and remarks have been placerl in another colnmn. At the close $I$ hare added a condensed tabular statement of the names and positious of the serenty places mentioned by Cabrillo and Ferrelo and which I have identified. In the narratives I hare oceasionally added a note or condensed statement in brackets [ ].

In regard to the name "California," I extract the following note from the California Const Pilot alreatly referied to:

"The name California is first fonnd in the worthless romauce "Las Sergas of Esplindian, the son of Amadis of Ganl, written by Gareia Ardonez de Montalvo, the translator of the Amadis. It was first printed in 1510, with ellitions in 1519, 1521, 1525, 1526 (two), 1575, 1587, and the recent reprint of 1857.*

"The name appears in sereral passages, of which the following are given:

" "Know that, on the right hand of the Indies, very near to the Terrestrial Paradise, there is an island ealled California. which was peopled with black women, withont any men among them, because they were acenstomed to live after the fashion of Amazons.

" 'In this island ealled California are many Griffins, on account of the great sarageness of the country aud the immense quantity of wild game found there.

" "Now in the time that those great men of the Pagans sailed (against Constantinople) with those great fleets of which I have told you, there reigned in this land of Calif:-rnia a Queen, largo of bods, very beantiint, in the prime of her years, \&c.

"The name Califoruia next occurs in the nemoirs of the Conquistador, Berual Diaz del Castillo, who served with Cortes in the conqnest of Mexico. He writes that "Cortes again set sail from Santa Cruz and discorered the coast of California." Here Cortes remained for some timc, disheartened at the want of suceess of his rarions expeditions. The riceros, Mendoza, dispatched

- The full title of the book is "Las Sergas del Mey Lsforxarlo Cabalero Esplandian hijo del exeelente re Amadis de Gaula." 
a ressei under the command of Ulloa with letters to Cortes. "Ulloa had a most favorable voyage and soon arriverl in the harbor where Cortes lay at anchor. The letter's of his wife and those of his cuildren, aud of the viceroy, had so much effect upon him that he gave the command of his ressel to Ulioa, embarked for Acapulco, and when he had arrived there hastened to Quanhuabuac, where his wife resided. *** Shortly after, also, the troops arrived which had been left behind in California."

"After a few months' repose Cortes sent ont a more considerable expedition, under command of Ulloa. "This armanent left the harbor de la Naridad in the month of June of one thousand five hundred and thirty, and so many sears-I forget the exact year."

"The California referred to above is the peninsula of that name, generally known as Lower Califurnia, aud the date 1535 . They are the only times in which Diaz nses the name. (Cap. C. C.)

"In 1539 Franeisco de Ulloa deteruined Lower Califoruia to be a peninsula. This fact appears to have beeu subsequently forgotten, for it was called La Isla de Las Carolinas, in honor of Charles II of Spain, and late in the last centurs the eliarts contiuned to delineate it as a great island parallel to the coutinental coast.

"The name Califoruia was gradually used to designate the region from the Gulf of California to the mythical "Straits of Anian," (which were very probably Beriug Straits).

"The conutry was called New Albion by Sir Francis Drake in 1579.

"In recent times the region nortl of San Diego was called Alta California, aud that to the sonth Baja Califoruia.""

I eheerfully express my thanks to Joln T. Doyle, esq., and to H. H. Bancroft, esq., of San Irancisco, for conrtesies exteuded in $m y$ exawination of some of the older authoricies; and to E. J. Molera, esq., for assistance in rendering several old Spanish idiomatic phrases.

The principal works whicb I lat ve consulted are-

(A) Ulloa.-There is no Spauish record or book of his exploratious. The Italian accont is in the third volnme of the Navigations and Vosages of Gio. Battista Ramusio, pp. 339-354, published in Verice in 1865. It is published in English, in Hakluyt, Voyages III, 1p. 397-424. The title is:

Ulloa. Relat: mo della Scoprimento che nel nome di Dio va d̀ far l'armata dell' illustrissimo Feruando Cortese, Marichese di Valle con tri Naui, chiamata l'una Santa Agata, di Grandezza di dugento quaranta botto, l'altra, la Trinita, di grandezza di settanta.e la terza San Tomaso, di quaráta, dellaquale armata su Capitano il molto Magnifico Ganaliero Franceseo di VLLOA habitator della città di MIeridi..

(B) Cabrillo.-Historia General de los Hechos de los Castellanos en las Islas y Tierra Firme rlel Mar Oceano, Eserita por Antonio de Herrera Corouista Major de Su Magestad de las Iudias y Coronista de Castilla y Leon Decada Setina al Rey Nuestro Señor En Madrid en la Officina Real de Nicolas Tiodrignez Franeo 1730. Cou Privilegio de Su Majestad.

Libro Qninto Cap. III. Del riaje que hicieron dos Navios, que embiò Don Autonio de Meudoça à descubrir la Costa de la Mar del Sur, desile Nneva-España. Cap. IV. Que prosigue el descubrimiento de los dos Narios de Dou Antonio de Mendoça por la Mar del Sùd.

(C) Ferrelo.-Collecion de varios documentos Para la Historia de la Florida y tierras adyacentes. Largas en fazañas é cortos en descrebillas. Tomo I. Lu la easa de Tribuer y Compañia. Núm. 60, Pateruoster Row, Londres. (Se han tiracio 500 Ejamplases jor José Rodriguez, Madrid, Año de 1557, 1. 173. Mar del Sur. 1542. Relaeion, ó diario, de la Navegaeion que hizo Juan Rodrignez Cabrillo con dos Narios, al deseubrimiento del paso del Mar del Sur al Nortes desde 27 de Jurín de 1542 que Salió del puerto de Naridal, hasta 14 de Abril del Siguiente año que se restituyó ál, naviendo llegado hasta el altura de 44 grados, con la deseripcion de la Costa, puertos, ensanadas, ź islas que reconoció y sus distancias, en la extension de toda aquella costa.

(D) Drake.-The English Hero: or, Sir Fraucis Drake rerired. Being a full account of the 4lıugerous Voyages, admirable Adrentures, notable Discoveries, and magnanimons Athievements, of that raliant and renowned Commander. I. His Voyages in 1572, to Nombre de Dios in the Trest Indies, where they saw a Pile of silrer Bars nearly 70 Feet long, 10 Feet broad, aud 12 Feet nigh. II. Mis encompassing the whole World in $155 \%$, which he performed in two Years, aud ten Houths, gainiug a vast quantity of Gold and Silrer. III. His voyage into America in 15Sí, and takiug the towns of St. Iago, St. Domingo, Carthagena, aud St. Augustine. Also his worthy 
actions when Vice Admiral of England in the Spanish Invasion, 1588. IV. His last royage in those Countries, in 1595, with the manner of his Death and Burial. Recommended to the Imitation of all heroic Spirits. Enlarged and reduced into Chapters with Contents. By R. B. The twelfth Edition. Dublin: Pricted for G. Golding at the King's Head in High-street, 1739.

(E) Drake.-The World Encompassed by Sir Francis Drake, Being bis next voyage to that to Nombre de Dios. Collated with an Unpublished Manuscript of Francis Fletcher, Chaplain to the Expedition; with appendices iliustrative of the same Voyage, and Introduction, by W. S. Vanx Esq. M. A., London: Printed for the Bakluyt Society, M.D. CCCLIV.

(F) V'cnegas.-Noticia de la California, y de su conquista temporal y espiritual hasta el tienpo presenti, sacada de la Historia Manuscrita, formada en Mexico año de 1739, por el Padre Miguel Venegas, de la Compañia de Jesus: $y$ de otras Noticias, $y$ Relationes antiguas, y modernas: Anadida de Algunos mapas particulares; $y$ uno general de la America Septentrional, Assia Oriental, y Mar del Sur intermedio, formados solore las Memorias mas recientes, $s$ exactas, que se publican justamente: hedicala al Rey Ntro. Señor por la Provincia de Nneva-Espana, de la Compañia de Jesus. Tomo Tercero. Con licencia En Madrid: En la Imprenta de la Viceda de Minual Fernaudez, $s$ del Supremo Consejo de la Inquisicion. Aũo de M.DCC.IVII.

(G) Burncy.-A Chronological History of the Voyages and Discoreries in the South Sea or Pacific Ocean. Part I. Commencing with au acconnt of the earliest discorery of that Sea by Europeans, and terminating with the Voyage of Sir Francis Drake, in 15i9. Illustrated with Charts by James Burney; Captaiu iu the Royal Nary, London : printed by Luke Hansand, near Lincolu'sInu-Fields, and sold by U. and W. Nichol, Bookscller to His Majesty, Pall Nall; G. ant J. Robinson, Paternoster Row; r. Robson, New Bond Street; Mem's Gate; and Cadell and Davis, in the Strand, 1803.

(II) Enginecr Department U. S. Army.-Report upon Uniterl States Geographical Surreys west of the one hundredth meridian, in charge of First Lientenant Geo. M. Wheeler, Corps of Eaginecrs, U. S. Army, under the direction of Brig. General A. A. Humphreys, Chief of Engineers, U. S. Army. Published by authority of the Honorable Secretary of War, in accordance with acts of Congress of Jume 231,1874, and February 15th, 1875, in sereral rolnimes, accompanied by one topographical and one geological atlas. Vol. VII. Archeolog.r, Washington: Gorerumeut Printing Office, 1879. (Appendix to Part I, Vol. VII, pp. 292-314.)

(I) No. 56 U. S. Hydrographic Offee-Bureau of Naxigation. The West Coast of Mexico, from the Boundary Line between the United States and Mexico to Cape Corrientes, including the Gunf of California. Washiugton: Government Priuting Office. 1880.

(J) United States Coast and Geodetic Survey, W. M. Thom, Superintendent. Pacific Coast. Coast Pilot of California, Oregon, and Washington. Fourth edition: BS George Davidson, Assistant. 1886. [Jet in manuscript, August, 1S86.]

The mork upon this investigation has been done at intervals, independently of the regular duties of the U. S. Coast and Creoletic Surrey, and has therefore been a long time in hand.

San Francisco, Calı, August, 1886. 


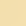


The Port of Navidad is in latitude $19^{\circ} 13^{\prime} \mathrm{N}$. and tweuty miles west-northwest from the harbor of Mansanilla.

El Cabo de Corrientes, in 2010, Cabrillo. Latitude $20^{\circ} 25^{\prime}$ : correction to Cabrillo, $-0^{\circ} 05^{\prime}$ if he observed the latitude, which I very much donbt.

Thirty leagnes, by the charts.

La Bahia de Santa Cruz, Ulloa.

EI Puerto de la Cruz, : $4^{\circ}$ and "more," Cabrillo.

Él Pnerto del Marques del Valle.

(The Emperor lad given Cortes the title of Mlarques del Valle del Quaxaco in 1528.) This port is probably the cove under Cape Pulmo.

The Point of California "in $24^{\circ}$ and more," is quite likely the present Cape Pulmo which is the easternmost land of the pexiusula of Lower California, and placed in latitude $23^{\circ} 23^{\prime}$, so that the correction to Cabrillo would be $-0^{\circ} 3 \mathrm{y}^{\prime}$ " and more." Hence to Cape San Lucas following the coast line the distance is 44 geographical miles.

The cliffs at Cape Pulmo are 410 feet above the sea, and within a nile the hill rises to 850 feet with a low neck or valley behixd it, so that from the northward or southward this hill presents a notable feature. Inside of this the mountains eight miles westwardly rise to 2,8:5 feet, while Miratlores of the Sierra la Victoria, 27 miles from the gulf shore, rises to 6,200 feet eleration: the former is visible, at 62 miles distance, the latter at 91 miles.

On the sonth side of Cape Pulmo there is a nice cove three-quarters of a mile deep whero auchorage may be Lad in ten fathoms within two huudred yards of the beach. Fresh water is fonnd in the arrogo which opens on the cove.

This bay is probably the Puerto del Marques del Valle where one of Cortes ships putin duriug the expedition of 1534, and where Ximeues the Captaiu (who had mutinied as pilot) was killed. The bay of Santa Cruz was visited by Cortes himself in 1536. Iu 1596 El General Vizcaino, under orders of Don Gaspar de Znuiga Conde de Mloute-Rey, visited the easteru shore of the southerm end of the Peninsula of California and renained eight clays at the Puerto de Sin Sebastian, but abaudoned it for a more convenient place, and sailing furtler they came to the Puerto de Ia Puz. This Puerto de Santa Uruz nıy therefore be reasowably considered the same as that of the Harqnesilel Ville.
Juan Rodriguez set sail from the Puerlo de Navidad lo discover the coast of New Spain on the 27th day of June, 1542.

He was delased from the Puerto de Navidad to Cabo Corrientes a day and a uight, forty leagues, with a southeast wind.

From Wednesday to the following Thursday they held their course aloug the coast thirty-five leagues.

Susday, the second day of July, they had sight of Califormia: they were delayed in crossing over, by the weather, which was not very favorable, almost four days; they anchored the following Monday, on the third of the same, off the Point of Califoruia, and were here two days, and from this place 


\section{CABRILLO.}

Don Antonio de Meudoca took nore inferest in maritime matters, for notwithstanding the vessels he had sent to discover that part of the coast of New Spain, towards the Soutl, had suffered a great deal, he sought, by every means, to know what there was fuxther on, and for that purpose he ordered two ressels to be fitted out, and appointed for Captain of them Juan Rodrignez Cabrillo, a Portuguese, a persou very conversant with the matters of the sea.

One of the ressels was named the Sau Salvador, which was the flagship, and the other La Victoria; there was for chief pilot Bartolomè Ferrer, and also for pilot Bartolomè Fernazdez; and for inasters Antonio Carrera, and S. Remo.

These vessels being quickly made ready, they sailed from the Puerto de Navidad, on the trienty-serenth of June. of the present year, [1542,] at noon, and arived early in the morning at Cabo de Corrientes in twenty degrees and a half.

Frislas, on the 30th, running along the coast, they found themselves in twenty and two degrees, and a third.

Sunday, on the second of July, they found themselves in twenty and four degrees and more, and recognized the Puerto del Marquez del Valle, which they called de la Cruz, which is the Coast of California.

\section{ULLOA AND VIZCAINO.}

VIZCAÌxo.

[Vizcaino, with his three vessels and a long boat, left Puerto de la Navidad on the twenty-second of May 1602; continning his course with adverse wiuds nearly to Cape Corrientes where he arrived on the twenty-sixtl; and after a survey of that vicinity be proceeded along the Coast to Mazatlau, where he arrived June second.]

\section{ELLOA.}

"On the eighteenth of Octolser, they reached the bay of Santa Cruz. Oetolyer twents ninth, [1539], Ulloa sailed with the Santa Agneda and the Trinidad, from the bas ot Santa $\mathrm{Cr} u z$, to follow, is before, the trend of the coast: but being impeded by contrary winds, he lad advanced on the tenth of November not more than fifts-fonr leagnes from the bay of Santa Cruz towards the south and southwest."

\section{YIZCAIับo.}

[From Weduesday to the following Thursday they held their conrse along the coast of Nen Spain thirty-five leagnes.]

"Sundar, on the second day of $\mathrm{Jul} F$, they had sight of California: they were delayed in crossing over [the Gulf of California] by the weather, which was not very farolable, almost fonr lars; the anchored the follorring MIonday, on the third of the same month, off the Point of California, aud were here two days." 


\section{DAVIDSON.}

El Puerto de San Lucas, "Plicy say it is in latitucle 230," Ferrelo:

La Bahia de San Beruahè, Vizcaino:

San Lreas Bay; latitude 2.20 52'.

Correction to Ferrelo, $-0 \circ 08^{\prime}$. Either FerTelo obtainerl the latitude at second authority, or his instrument was badly deranged thereafter, as well as at Santa Cruz; I think the former.

It was in this harbor of San Lucas that the English navigator Cavendish, in 158\%, eaptured, plundered, and burnt the Spanish galleon Santa Ana from the PLilippines. This name suggests this bay as that where the Mexican astronomers observed the Trausit of Venus in 1769 , hen the French expedition under Auteroche de la Chappe eceupied a station at San Jose del Cabo, a few miles eastwardls, which I recovered in 18 i3.

San Lucas Bay affords good anchorage and shelter from the northwest and sonthwest winds, but it is open to the sea from the senth to the east, rendering it exceedingly unsafe during the summer and antinm, or wet season, when the gales are very frequent and riolent. The best anehorage is in six or seven fathoms of water, a quarter of a mile from the beach. Woodand water are obtained here.

Vizcaine gives a full description of the uatives, the fresh-water lake, the fishes, and the productions of the lancl.

La Punta de la Trinidad. Cabrillo; Ferrelo in $25^{\circ}$. This is undoutedly

Cape Toseo, in latitude 24 $17^{\prime}$. Correction to Cabrillo and Ferrelo, $-0^{\circ} 43^{\prime}$.

From Cape San Lucas to Cape Tosco, a distauce ot 130 miles, or 43 leagues, there in no prominent point or indentation of the coast line, except imnediately under the latter cape. The shore is marked by loug lines of dreary saud dnnes, except near Cape Falso and half way hence to Cape Tosco, where there is a "low, rocky point called the Point del Mlarques. A reef of rocks extends a short distance ont from it, and on either side near the coast are low sands bluffs."

"Vessels may anchor anywhere along this part of the coast in fine.weather in fron 8 to 10 fathoms, a mile or twe from the beach. The sonndiugs are regular, and there are no bidden dangers. The beacl is generally steep, and the breakers close to it."

Immediately behind this point the land rises to "Las llesas," or table-lands, of 600 feet cleration. To the southeastwarl stretches a great chaiu of nonntains, reaching Cape San Lncas, and ranging from 4,000 to 6, 200 feet elevation; and visible at a distance of ninety-one miles.

The point is laid down on the U. S. Coast Survey chart iu latitnde $23^{\circ} 56^{\prime}$ north, and the inclications are ayaiust any anchorage when the nerthwest winds are blowing; although Ulloa anchored eight or ten leagues to the southeast of Pnerte Trinidad. Vizcaine met with strong currents from the northwest aloug this stretch of coast.

There must be some omission in Ferrelo's narratives wherein he gives the distance of five leagues fiom Cape San Lueas to Cape 'Tosco. The aetual distance is 43 leagues along the coast. His estimates are so vague that

\section{FERRELO.}

they reached the Puerto do San Lueas the following Thursday, and took in water; they saw these days no Indians: they say [dizen] that this port is in twentythree degrees, and from the point to the port it is clear and soundable, and the land is bare and rugged.

They departed from the Puerto de San Lucas Thursday, the 6th, in the night, aud the following Saturday, on the ejghth of the said month, they cast anchor nnder the Punta de la Trinidad, whieh is in twenty-tive degrees; it is from San Lucas five leagues; ${ }^{1}$ it is a clean coast withont any irregnlarity; within, on the land, appear high and bare and rugged ridges; they werc at auchor here on account of contrary winds from westnorthrest until the folluming Wednesday. 


\section{CABRILLO.}

On the eighth day of the same month, they found themselves in trenty and firedegrees, which is Ia Punta de la Triniclad.

\section{ULLOA AND VIZCAINO.}

$$
\text { ULLOA. }
$$

"The country near the southern cape of Califorzia was beantiful, and appeared to be well iubabited. 'The shore was bold, the least depth, as they sailed, being fifty-four fathoms.

The coast [bordering the Pacific Ocean] was soon found to take a northern direction, and their progress was opposed by a long continuance of northwest winds. The two slips were separated and rejoined twice withiu the first month ifter quitting Santa Cruz."

\section{VIZcAìno.}

" The squadron of Vizcaìno entcring this bay under Cabo ile San Lueas, on the feast of San Barnabas [June 11tin], it was called after the name of that Saint. * * * ln this bay the squadron lay some days to wait for the change of the moon, repair the ships, and take in wood and water. *** (P. 38.) Three times the squadron sailed ont of the bay, and were as often through the violence of the wind and the roughness of the sea, obliged to put back. They again set sail on the 5th of July, which was the fourth time (p. 46)." " .

\section{ULLOA.}

[On the first of December, they anchored near the coast $t_{5}$ and boats went to procure water; in doing which, they were attacked by the natives. Captain Ulloa and some others were mounded, not dangerously,] "and Berecillo, their lest mastiff dog, (they had two others) was wounded. with three arrows, and wonld no more returu to the charge."

[Near this watering place they found a bay or port, with three fathoms depth at the entrance, and deeper water within. Nolatitude is nentioued.]

vizcaìno.

"Awd coming near the shore on the Sth of the month, facing some highlands, they were becalmed, that in a week they did not gain a single league; and on this acconnt they gare that high land the name Sierra del Enfado, or Monut Tiresome (p. 47)."

[On his chart Vizcaino simply says "This coast is free. fram dlangers" half way to Cape 'Tosco, and hence to. Tosco "low beaches." The chart has a weak point near. the prescut Point del Mlarquis. ] 


\section{DAVIDSON.}

no supposition can fairly be macle as to what he intencied to say.

La Punta de la 'Trinidad, 250, C'abrillo.

El Pnerte de Ia Trividad, $25^{\circ}$, Ferrelo.

La Bahia dê San Abad, Ulloa.

La Bahì enganosa de Sarta Marina, Vizeaine (p.51).

El Puerto del Marquès, ò de Santiago of Vizcaìo (13. 52).

La Bahì de Sauta Marima, Vizcaiuo's chart.

Santa Marina Bay, in latitude $24^{\circ} 20^{\prime}$.

Santa Margarita Islaut. It is twenty-two miles loug, abont fire miles broad at the broadest place, and rises in barreu peaks to 1,900 feet eleration.

Lil Puerto de San Pedro, 25:

EI Puerto do la Magdalena, Vizcaino (1. 49).

La Bahia ò Pnerto de la Magdalena, Vizcaino, pages 50,5:, aud chart.

Magualena Bay is in latitude $24^{\circ} 32^{\prime}$; correction, to Ferrelo $-0^{\circ} 58^{\prime}$.

This large aud spacious bay with a tine entrance three suiles witle, with very rleep water and high headlauds, is well protected by great monntain barriers from the Pavific Ocean winds.

The magnificent sheet of water is thirty-tive miles long by twelve miles broad, but is divirled by a narrow threat into Magdalena Bay proper on the north, and Almega Bay on the south; the latter agaiu opening southward inte Santa Marina Bay. The depth of water in the two wain bays is over ten fathoms. From the worthre part of Magdalena Bay there is connection with a long line of lagoons running for sixty miles northward, and Iying just inside the coast sand dunes. These lagoons have several openings to the sea, through the dumes, and were former] y the resort of iunumerable whales.

El Morro Redoudo, Vizcaìno's elart.

Cape Redondo, in Iatitude 2.10 3:".

The vorthern point of the entrance to Magdaleua Bay is Entrada Point.

La Bahia de Sau Martiu, Ferrelo.

La Bahì de Sauta Marta, Vizcaino's chart.

Santa Maria Bay, latitude $24^{\circ} 44^{\prime}$.

This bay is four leagues northrestward from the entrance to Magdaleua Bay, and lies bread open to the sonthwestward. It is eight miles between the nerthwest and sontheast points of the entrance, and it is fonr and a half miles deep towards the wortheast. The sonndings decrease regularly from twenty fathous to three fathoms at the sandy beach, which is backed by saud dunes. There are ne daugers except a line of rocks extending half a mile frou Cape Lazaro, which forms the north ir est point. Inside the bay, on the east side of Cape Lazaro, there is good anchorage in six fathoms of water over sandy bottom. The seutheast point of entrance to the bay is Cape Corso. When Cabri]lo had reached El Puerto rle la Magdalena or Peqneña, in latitude $27^{\circ}$ by his reckoning, lie says "This puerte is forty leagnes from the bay of San IIartin;" this would put it approximately in his latitude of $25^{\circ}$; but he makes ne mention of such a port iu lis narrative when he was sailing past that part of the coast : although he hau jnst ls ff Santa Marina Bay and
FERRER

Wednesdiy, on tha twelfth day of said month, they leparted from this place. In Puerte de la Trinidad, an island forms the port which is here, and it is a good port, sheltered from tho west-northwest winds; the port of the island is at the head of the island ou the sonthenst sicle, and the port is clear ant soundable; it has neither wook nor water; the island has ten leagues of length and two leagues of brealtli; they anchored that night.

They departed the Thursclay following, and passed the Pnerto de San Pedro, which is in trenty-five and a half clegrees; in this port there is no water nor wood; its clirection is southeast; it has a good shelter from the west winds; 
ULLOA.

"Eight or ten leagues farther to the Northrest, they caune to some inlets like passages between islands, into one of which they sailed, and found a good harbor entirely enelosed with land, which they naned Bahìa de Sau Albad. The latitude is not given. In this port they took a supply of water, and at this part of the coast they had interconrse with the natives, who exchanged pearl shells and feathers for beards and other triukets; but this traffic was condicted with much cantion and distrust. aud their separation was not friendly."

\section{vizcaìo.}

"(P. 49.) Vizeaino's llagship enterea the oay on the 20 tn of $\mathrm{July}, 1602$, but her consort did not on acconnt of the fogs. The next day some soldiers ascended the mountain and saw her consort sailiug northr ard. The Capitaca being thus alone ou Santa Magdalena's day, the father Commissary and Father Tonas said mass ashore; and on account of this festival the hay was named La Bahia, or Puerto de Magdalena:- it is very spacious, with several safe coves and anchoring places; has two entrances, and through it a wide arm of the sea runs up into the country. *** (P. 50.) The firigate subsequently entered the bay, joined the Capitana, and both left in company (p. 51)."

[Vizeaino's chart gives his ancherage in the Bay, the soundings, and the eastern passage to Santa.Marina Bay. He designates it as La Bahì de la Magdaleua; and the southern point of the entrance is named Morro Redoulo.]

[About five miles beromi Magdalena Bay he diseovered the entrance to what appeared a very dangerous bay, but it had been entered by the Almiranta and is named on the chart La Bahia de Sta. Marta.] 


\section{DAYIDSON.}

looked iuto the preseut Magdalena Bay. As there is no other port immediately north of Magdalena Bas, it is reasonablo to assume that La Bahia de San Martin and Santa Maria Bay are the same ports.

La Punta de San Lazaro, Vizcano's cbart.

Cape Sau Lazaro, iu latitude $24^{\circ} 48^{\prime}$.

From Cape San Lazaro the coast line takes a clecided change of direction from west-yorthwest to vorth (magnetic), and also changes from the bigh wountainous rauge from Cape Tosco to Cape San Lazaro, to one that is low, saudy, and ouly broken by the entrance to great lagoons that stretch sixty miles north ward from Magdalena Bay.

It is very probable that the receding of this low shore caused Ferrelo to designate it the head of a large enseuada or gulf; or else that he saw the great lagoous from the mast-head; in either case ther would head in abont la

La Bahia de San Christoval, Vizcaino. In this eusemada is the entrance to the Boca de San Domingo, in latitude $25^{\circ} 21^{\prime}$. It is three-quarters of a mile wide, with a shoal extending a mile off the entrance. There is a depth of seven and a half feet of water mpon it at high ticle. 'The sonthern end of the lagoon heads in Magdalena Bay', aud also stretches northward thirty miles. A very low country lies to the castward of it.

El Pncrto de la Magdalena, 270, Cabrillo and Ferrelo. Pequeña Bay, in latitude $26^{\circ} 14^{\prime}$. Correction to Cabrillo and Ferrelo, $-0^{\circ} 46^{\prime}$. The distauce from Santa Maria Bay is ouly thirty leagues.

This is a bay formed by an indentation of the coast, one aud a balf miles to the northward. The rocky point on the west is composed of rolenuic bluffs thirty feet high, witl a hill eighty-firo feet high. The comntry is low, with sand dumes aud lagoons farther in shore.

Vessels find shelter from the northwesters by aucloring in six fathoms of water one mile uortheastward from the point. There is a large estero behind the point, lunt in some seasons it has uo opening to the sea.

Vizcaino has a line of sonndiugs along the shore firom Cape Lazaro nearly to Point $\Lambda$ breojos, rauging from thirty to fifteen fathoms of water. And he has two indentatious corresponding very nearly in position to Peqneña Bay aud the open roadstead under Point San Domingo. His chart says this is a "brokeu, ragged const," aur inlaud "mountainous." Both statements are true. The cliarts of 1874 named the point forming Pequeña Bay, San Domingo; bnt on the latest eharts it has no naue, and San Domingo is trausferred to the point thirteen miles to the west-northwest.

La Puuta do Santa Catalina, Ferrolo.

San Domingo Point, of the latest charts; it is in latitude $26^{\circ} 19^{\prime}$, and thirteen miles west-yorthwest from $P t$ queña Bayฺ.
FERRELO,

-

they contimed sailing along the coast, which forms a large gulf, the head of which is in twenty-six dogrees; the laud is low and covered with sand dunes, the coast white and clear; thes proceeded, sailing aloug the coast with fair winds

as far as twenty-seven degrees, aud Weduesday, ou the vineteenth of the said month, ther landed at a port which they discovered, and going on shore they found a path nsed by Indians, and followed it the distance of an arcuebuse shot, where they fonud a spring of water; the laud is level within and bare and very drs; they gave it the name of Puerto ile la MIadaena; it is forty leagues from the Bay of Say Martin to this port.

The following Thurstay, on the twentieth of this month, they departed from this port and proceeded, sailing along the coast with contrary winds, and about six leagues from that place they found an auchorage behind 


\section{CABRILLO.}

ULLOA AND VIZCAİNO.

[On Vizcaino's chart he names the head which forms the northwest point of Santa Maria Bay, La Punta de San Lazaro.]

"The wbole coast beyond this cape is level and pleasant; and has only a few monutains in the inland conutry."

"On the 30th of July, they had sight of a baj, which seemed to be formet there by the issue of a river. * * (P. 52.) There were breakers at the entrance.

This place or gulf had been surveyed by the Almiranta. It Tas nawed the Bahia de San Christoval, * * * because it was surveyed on the anniversary of that saint.' (P. 53.)

[The chart designates it as a "low coast."]

Wednesday, on the nineteenth, they discovered a port which is of good protection, which they called La Magdalena, in twenty-seren degrees, and here theg took in water. 


\section{DAVIDSON.}

San Domiugo Puint is a remarkable perpendienlar rocky eliff of dark color, rising one bundred and seventy. five fect above the sea. The eliffs extend for several miles east and west of the Poiut. A short reef stretches ont from the Point in a south westerly direction. Anchorage may be had to the eastward of the Point, under its lee, in tive or six fatloms of water, half a mile from the shore, where a ressel will find some protection from the prevailing wind.

To the northwestward of this Puint a long line of lagoens lies just inside the saut dunes. Behind the lagoons the land is low and sandy and then rises gently to low table-lands. The mountains are from twenty to thirts miles inlancl.

El Puerto de Santiago, $27 \frac{10}{2}$, Ferrelo.

La Bahìa de las Ballenas, Vizcaino.

Ballenas Bas, latiturle $26^{\circ} 45^{\prime}$.

San Ignacio Lagoon, under Abreójos Point, in latitnde $20^{\circ} 42^{\prime}$; correction to Ferrelo, $-0^{\circ} 45^{\prime}$. It is 76 miles from Poqueña Bay, and 54 miles from San Domingo Point.

'The whole bight east and southeast of Abreójos Point, for fifty miles, is bortered by low sandy shores, behind which stretch immense lagoons, which were the former hannts of the humpback whale. The San I gnacio Lageon, seventeen miles east-northeast from Abreójos Point, penetrates twenty miles northward and has a channel that adnitted whaling ressels (1654). Between this lagoon and Abreójos Point there is another largo lagoon not named. From Ignacio Bay to San Domingo Point there is the loug line of narrow lageons already mentioned. The early navigators may rery readily bave imagined an extensive and deep bay lying well to the eastward of Point Abreójos, and stretching eastward and worthward from and forming part of the Pnerte Santiago. The highlands for thirty or forty miles retreat inland behind the San Ignacio Lagoon or Pnerto.

The open bay just inside Abreojos Point is named Ballenas Bay; it is sixteen miles broad, east and west, and seren miles deep, north and sonth. The depth of water in it ranges from twenty fathoms to three fathoms close under the beach. The Point affords good protection from the prevailing winds of summer. An auchorage is bad in sis to seren fathoms of water over sandy loottom. With st rong winds a large swell rolls in, cansing a heavy snrt on the beach.

The Point itself is low and sandy, with a long narrow lagoon stretehing to the west-northwest. 'There is a barren hill 277 feet high three miles inside the Point. On its southeast side there is a pond with brackish water in it during the dry seasen. A ridge running northnorthrest from the Point rises to monntains in twenty rniles.

La Punta de Sautiago, Ferrelo.

Abreójos Point.

Habre Ojo (Rocks), "lieep your eรe open", 27 $\frac{10}{2}$ and and "more," Ferrelo.

The Ahreójos Recks, latitude $26^{\circ} 46^{\prime}$.

Correction to Ferrelo, $-0^{\circ} 44^{\prime}$ " and more.

Whale Rock.

These dangers lie three wiles west-sonthwest from Alurégos Point, and are about two miles in oxtent. One of them, Whale Rock, is four feet above water; the rest
l'ERREI.O.

a point, which they eilled Punta de Santa Catalina, and so.tley continnerl sililing along the const,

and the Tnesday following, on the twenty-fith of the said month of July, they discoverel a large bay in twentyseren and a half deyrees; they made very little progress these dass on account of the bad weather; they clropped anchor in this port and gave it the name of Puerto de Santiage; it is distaut from Pnerto de Madalena twentythree leagues;

there are from Puuta de Santiago for five leagues some very dangerons shoals aud rocks, and they do not appear except when the sea breaks upen then; thes are one leagne from the land, and in a little over twenty.seven aud a half degrees; ther are called Haljre Ojo. 
"And the same night [ July 30th] (p.53), they contintied their voyage nutil they came to the Bahìa de las Ballenas; when approaching it, "at a considerable distance they saw a large bay, * * * (p. 54), but on approaching, it was fonnd to be as it were intercepted by shoals.

* * This bay [Ensenada] had bcen survejed by the Almiranta, who gave it the name of Bahia de Ballenas on acconnt of the nuititndes of that large fish they saw there." They could not land for two days. The country is quite populons and the Indians peaceable.

[Vizeaino's chart exhibits this rreat bight east of $\mathrm{Ab}$ reójos Point, with a long barrier of sand through it as if guarding the lagoons behind it. In front of this barrier is the legend "Arrecifes."]

[Vizcaino's chart has the sunken rocks off the point named "Abreojos:" and he evidently anchored nuder the point as his anchor denotes.]

H. Ex. $40-22$ 


\section{DAVIDSON.}

are sunken. The distance around them and the danger jnst off the point is eight or nine miles.

La Bahia de Sau Hipolito, Vizcaino's chart.

San Hipolito Bay, latitucle $26^{\circ} 58^{\prime}$.

This open bay is formed by the indentation of the coast line east of Poiat San Hipolito. The easteru shore runs north for three miles and then sweeps to the eastward and sontheastward for ten miles. Good anehorage may be had under the lee of tho Point in fire to seven fathoms of water over a sandy bottom, at half a mile from the low shore.

San Hipolito Point is quite low, and composed of blaek roek with barren sand hills fifty to one hundred feet high, rising a short distauce from it. There is a sandy shoal extending over a mile from the Point.

A remarkable table-shaped mountain, of 1,227 feet elevation, lies five and a half miles north (maguetic) from the Point. Behind this rise higher monntains. three thousand feet in elevation.

Sierra de los Siete Infuntes, Vizeaiuo.

These seven peaks are in the mountain rauge, lyiug betreen Abreójos Point and San Roque Islaud, and abont fifteein miles iuland. They are not recoguized on auy of the charts to date. The ranige reaches an elevation of 3,400 feet.

Punta s Puerto de Santa Ana, 28, Ferrelo.

Asuncion Point, latitude $25^{\circ} 0 \tau^{\prime}$. Correetion to Ferrelo, $-0^{\circ} 53^{\prime}$.

It is forty-seren milos in a straight line from Abreójos Point.

It is a low, sluarp, bluff Point, with a cone-shaped hillock abont seventy-five feet high at its outer extremity, and moderatels high hills a short distance inland.

\section{Asuncion Islaut.}

San Roque Island.

These are the islands discovered by Ulloa, but not then nawed; nor were they named by Cabrillo.

Las Islas do San Roqne, Vizeaino in the Almiranta.

La Isla de la Assumpcion, by the Capitana; this is the first or soutlern islet.

La 1sla de San Roque, Vizcaìno.

They are both named on his ehart, with an auchorage under each.

Asuucion Island lies a little more than three-quarters of a mile to the south-south east of Asuncion Point, and is placed in latitude $27^{\circ} 06^{\prime}$. It is three-quarters of a mile long, and less than a quarter of a mile wide; of saudstone formation, and entirely barren; towards its sonthern eud some hills reach an altitnde of one bundred feet.

The Island of San Ronue is a rugged rock, one mile Iong east and west, less than half a mile wide at its broadest part, and abont forty feet above the sea. It lies in the midulle of Sau Roque Bay, about tro miles from the shore, and has dangers off' its eastern extrenit.

It is in latitude $2 \gamma^{\circ} 08 \frac{1}{2}^{\prime}$, and is twenty-fivo miles from Point San Hipolito, and six miles from Asuncion Island.

\section{FERRELO}

Thes proceeded sailing on the same course aloug the coast, as far as trenty-eiglat degrees, and there anchored nuder shelter of a point. Here are groves of trees whieh they had not seen from the Point of California; it is from this point ${ }^{2}$ to Puerto de Santiago at the portlumest point twenty-tbree leagnes. There are high and broken ridges with some woodland. We gave it the name of Sarta Ana;

It has an islet abont a leagne from the land. 
[Vizcaino's cliart locates a bay about half way betreeu the Abreojos and Asuueion Island; he desiguates it as la Bahia de San Hipolito (p. 56). They sailed up it, and came to an anchor: but some soldiers being sent ashore in senreh of wood and water, they found the country evergnhere extremely barren, and therefore returned on board $(\mathrm{p}, 56)$.

"Midway between the bay of Ballenas aud the Islands of San Roque there is a high Sierra from whieh project seven high aud distinet peaks in line, and which have been named de las Siete Infantes [the seven Infauts] (p. 5:6).

ULLOA.

"Almost the whole mouth of December [1539] the ninds blew from the northwest, iu which direction the coast was found to continue. At times lhey advanced a little, lut at other times they were driven baek. The first of January [1540] thes arrived in sight of two small islauds near the mainland;

VIZCAT̃O.

[Vizcano in the Almiranta nas separated from the Capitana and Fragata, and discorered the Islas cle San Roque (p. 56-57). Tho Capitaua eoasting nuder the same shores reached the first island on the evening of the Assumpeion (Angust 5th) and gave it the yame Isla de la Assumpeion; the other island was two leagnes further ou, to which he sailed, and under which he anchored.]

"The islaud is of middling size, the soil sands and gravelly, and eovered with sea gulls. In some of the eoves there are infuite uumbers of sea wolves."

This island was pamed Isla de San Roque (1.50). 


\section{DAVIDSON.}

El Puerto Fondo, Ferrelo.

Table Head Core or San Pablo Bay, in latitudo $27^{\circ}$ II', $^{\prime}$ and about ten miles from Asuvcion Point. It is an open bay about one aud a half miles deep, formed by an inclentation in the face of Tablo Head betreen the points named San Roqne and San Pablo. It is apparently free from all hiclden dangers, and affords good anchorage in from teu to fifteen fathoms of water, at about three-quarters of a mile from the shore.

The great headland, embracing Asuncion Point, Sau Roque Point, aud San Pablo Point, known on our charts as Table Head, has hills 560 to 800 fiet elevation, rising directly from the water; and the moutains reach 1,800 feet in six miles inland, and 3,400 feet in fifteen miles. It is the commencement of a rery high aud mountainous coast line hence to Point San Eugenio.

They auchored in the open bight eight miles east of tho Morro Hernoso, and now nawed the bay of San Cristoral, but withont any elaim to being reckoned a bas, for it is twenty-three miles broad aud only five miles deep.

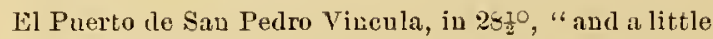
more," Firrelo.

El Puerto de Sau Bartolomè, Vizcaino.

Port San Bartolonè, in latitnde $27^{\circ} 39^{\prime}$; correction to Ferrelo, $00^{\circ} 55^{\prime}$.

The distanee from Tablo Head Core is eleven and a half leagues in a direct line.

"Port San Bartolomè is the best harbor on the west coast of Lower California between San Diego and Magdalena Bays. It is vearly circular in its general form, and is about tro and a half miles in diameter." "Vessels mar anchor anywhere in the bay." "The soundings are rery regular, and the bottom sand."

El Morro Hermoso, Vizcaìno.

Morro ITermoso (The Beutiful Rock). It is in latitude $27^{\circ} 30^{\prime}$, and lies trelve miles sontheast of Port San Bartolome and thirty-nine miles sontheast from the island of Cerros.

The seasard face of the Morro Hermoso is a hold, rocky elifi rising abruptly from the sea to a hill 900 feet in heighit. Inmediately behind it the monntain rises to 1,536 feet, with higher moutains a little further iulàud. "Besond the high and extensive table-lands of Point San Palblo there is a remarkable range of peaks from 2,000 to 3,000 feet eleration, and of variegated colors, corresponding well with Vizenino's description." Four miles east of the Morro Hermoso there is a peak 2,232 feet high, and only one nile from the shore.

Uloa, Cabrillo, aud Ferrelo do not mentiou the Morro Hermoso, althongh the last two were in tho Bay of San Bartolomè.

Thirty-five miles broal off the coast, in this latitude, the dcep plateau of the Pacitic Ocean is reached at 2,355 finthoms.

Island discovered, but not named, by Ulloa.

I a Isla do San Esteban, Ferrelo.

La Isla de la Natividad de Nuestra Señora, Vizcaino, in the AImiranta.

Afegua (or Bird Island), Iudian name, Taraval, 1734.

\section{FERRELO.}

Thursday, on the tweaty-sevonth of the same month, they departed from said Puerto de Santa Ana, and dropped anchor about six leagues from that place in a port which they named Puerto Foudo, on account of the great depth which it had, as near the land it had thirty fathoms; it is clear; aud they departed the following day from the said port, and turued back three times to the said port with contrary winds, ant thev were in the sairl bort until the followiug Monday.

Mouday, on the thirty-first of the same month, they departed from the atoresaid Puerto Fondo and anchored about eight leagnes thence that nigit, and the wext day they departed on their royage.

'Inesday, ou the tirst day of Ang!nst, they lett that [auchorage] place, aud they proceched about teu leagues, where thes anchored in a port to which they gare the nane of Sau Pedro Vincula; this port is in sirgt of the Isla de Zedros. This port is in twenty-eight and a half degrees, and more; the land is high and rugged and bare; from California to this place we bare seen vo Indian.

Welnesday, on the second of the said month, they departed from this port, aud the wind was contrary, and they proceeded beating; thes cast anchor under an island which is four leagues distant from the sontheast side of the isiand of Zciros, and they named this island San 
"The Capitana aud Fragata, not being hindered by the winds as the Almiranta was (p. 61), sailed into a good port, which they mamed de San Bartolomè. It is three leagues before you reach the island of Cerros.

They fonod no water on shere, and the land was extremely dry and sterile. And they fond on the beach a resin which did not have a good odor, and which some supposed to be auber, because tizero were great numbers of whales there. Whatever it was there was emough to load a ship. As this port was discovered on the day of the San Bartolomè Apostol, the twenty-fifth of Augnst, it was so named; aud that night they sailed (1. 62).

[The ehart shows "a rugged coast, withont trees." The bay is well indicated, and an anchorage laid domn under the north shore, well inside.]

"(P. 60.) The Almiranta, prosecnting her vosage [northwestward fron San Roque Island], came in sight of a very lofty mountain, at the base of which the sea broke, and which was twelve leagues from Cerros Island, which they could not reach. Here, to donble the point which the monntain makes, the Almiranta was more than eight days beating against the northwest winds, which were very strong. Every time they taeked they were withiu a stone's thow of the monntain and the mainland. This mountain has not a single herb or green thing, but it presents an appearauco as if painted, and variegated with different colors, like fancy tapes aud ribbous of every bne, so that it is a wouderful sight (p.61). * * * Finally the weather cleared up a little, the sea rent comil, and they doubled the eape.

When the Caputana and Fragata were in sight of la Sierra Piutada, they did not encounter the strong winds which bafted the Almirauta."

\section{ULLOA.}

"On Monday, the 5th of January, 1540, having adranced since the first of the month thirty-five leagues [from the Islands Asuncion and San Roque], they came to two other islands, wne of them wuch larger than the other, lying at some distance from the coast of the mainland. 


\section{DAVIDSON.}

Natividad Island, in latitnde $27^{\circ} 53^{\circ}$, aud its southern part is three leagues from Cerros Island.

Natividad Island is about three and three-quarters miles long, northrest and southeast, and from half a mile to a mile wide, being broadest at its southeastern end. It rises to 502 feot elevation; is hilly and barren, with mostly steep rocky shores surrounded by detached rocks acd kelp. The passage between the island and Point Engenio is nearly four miles wide.

Ou the southeasteru end of the island there is a sand beach half a mile long, and ressels may anchor otf this in ten fathoms of water among the kelp. But there are several dangers off this sonthern end of the island, such as Flat Rock ou which the sea breaks continually.

La Isla de los Cedros (Ulloa).

La Isla de Zetros, Ferre]o ; in $29 \circ$.

La Isla de Cerros, Vizeaino (p. 58 et seq.); and the same on his chart.

Amalgua (or Fog Islau(i), Indıa name: Taraval, 1734. Cerros Islant, latiturle of the sonthermnast point, $28002^{\prime}$. Correction to Ferrelo, $-0^{\circ} 58^{\prime}$.

El Cabo de San Augristin, Vizcaìno.

Cape San Angustin.

The change of name from Cerlros to Cerros was quite natural, for Vizeaino says (1. 6r), "Qne la Isla de Cerros tendria de box treinta leguas, $y$ en ella vieron grandes Pinares, $y$ Cedros, en las Corouas, de los mas altos Cerros." (That the island of Cerros is about thirty leagnes in cireuit, aud on it we saw great pines and cerlars on the summits of the highest mountains.)

The island lies veally north and sonth for twenty-one miles, with a broad base of nine miles at the southeru encl, and an average breadth of four miles. It is of volcanic origin, with numerous high peaks, the highest of which attains an elevation of 3,955 feet. In clear weather these peals may be seen from a distance of sixty miles. They were probably seen by the explorers fion the viciuity of Table Hear.

The eastern side of the island is a succession of rocky ledges and ravines, with the land rising abruptly in shar rilges and precipitons cliffs.

The worthern part of the island is formed by broken bluffis, and outlying rocks. A sharp peak, 1,761 feet high, with a crest of cedars, rises just back of this point.

The western side has the same general character as the eastern, lut with more ontlyiug rocks. Nauy of the crests of the western slopes of the monutains sustain cedars sixty to seventy feet in height. The character of the soutberu shore is much like the eastern, bnt under both the sea is comparatively smooth, and auchorage may be had in seren to ten fathoms of water close under the shore. Vizcaino notes five such anchorages on his chart. On the sonthenst side of Cape San Angustin, which is 832 feet in height, lies South liag with from fon to ten fathoms of water. An indentation of two and a balf miles forms this bay, where auchorage may bo had in seven fathoms of water, elose to tho shore, and sleltered from the prevailing winds, but open to the sontherly gales that ocew diung the early lart of tho winter. In
INERRELO.

Estebau. With the cxtremity [the northeru shore] of the point of the mainland runuing east and west, the coast [ to the southward] is northwest aud sontheast; it [the island] is a leagne from the mainland: from this point the maiuland turns the coist line towards the mortheast, and nukes a great gulf, so that the lauch is not visible. Between tho island aud the mainland there is a good channel, and they had to pass close to the island, for there are rocks which extend in a reef from the poiut for a quarter of a league. There is much vegetation on tho water, that grows from the bottom, and is matted beneath the surface. This island trends with San Pedro Vincula northwest and southeast; this islaud has three leagues in circuit. Wo were at this island with the wiud contrary until the following Saturday, the fifth of the said month of Angust. It has a good port on the side towards the sontheast. There is unnch fishing witb a hook, aud many birds are found.

They departed from the island of San Estehan Saturday, on the fifth day of August, and anchored at the Isla de Zedros, where they re mained until Thursday, the tenth of tho sail month, taking in water aud wook. They found no Indians, although they found somo sign of then. The leewarl point of this island on the sonth side is in twenty-nine degrees, and it has ou this sonth side good ports and water and wook, and it is on this part bare, as it has only some small bushes. 'The islaud is large aud high aud bare, and runs almost east and west, and is on this sille to the sonth twelve leagnes in length.

[See page 184 for mention of the island on the re:urn of the expedition.] 


\section{ULLOA AND VIZCAINO.}

They were high, and on the top of each were many tall, slender trees."

VIZCAỲYO.

"And the Almiranta proceeded towards the Nountain, or Island of Cerros, passing between the mainIand and a small island which they named the isla de la Natividad de Nuestra Señora (p.61).

The Capitana and the tender sailed from Port Bartholome on the 24th of Angust, in the wight, and they did not see the island of Natividad, but passed close to it (p. 62).

And they pamed the small island la Isla de la Natividad, and it is wholly a desert, with only one sort of wild fennel (p. 68)."

ULLOA.

"The large island was twenty leagues in eirenit, and was atterwards namerl Isla de los Cedros. * * * On the ninth of Jannary they were obliged to run back for shelter nnder the Ista de Cedros, near the south part of which they anchored in thirty fathoms.

This sicle of the island was monrtainons, and eovered with burut earth and ashes; * * * they did not see any appearance of vegetation. They landed, and by digging pits obtained water, in small quantity and of indifferent quality.

On the 14th, they anchored near the northern part of the island, which had a very different aspeet from the opposite extremity, being well covered with trees, and inhabited.

The next day they auchored in thirty fathoms, near an Indian village on the same island, and Captain Ulloa went with two boats to search for water. * * *

[Hchad a conflict with the Iudians, and his $\log$ Berecillo was badly beaten.]

The eances of these Indians were macie of the trunks of the cerlars, not hollowed, but merely fastened parallel and close to each other. Some of these trunks were twice the thiekness of a man, and six yards in length. On the hills in the north part of the island, there were groves ot these trees, for which reason the name Isla de los Cedros was given to the island."

\section{VIZCAìxo.}

"At claybreak on the 25th of August, the Capitana abl Pragata were elose to the Island of Cerros which the Adniral thought was the'mainland, and therefore he coasted to the westward; but it pleased our Lord, whom we serve, that for nine days they were unable to double a point which is part of the same island, and which he named el Cabo de San dugustin. Wearied by continual tacking the General determined to run elose under the land, where he thought he wonld be sheltered from the northrest winds; and after ho had anelored he sent for the Fragata, and in her the Cosmographer Geronynon Martin, to make a reeonnaissanee of the Island. And o 3 he came to an auchor under the south part of the Island of Cerros [in South Bay], on the last day of August. * * * Aud the Fragata discovered the Almiranta thi. diny and the fleet was reunited (p. 65)." 
DAVIDSON.

this bay Vizeaino anchored on the 31st of Angust, 1602. Father Taraval, in 1734, went with the Indians from Point Eigenio to these islands on the same kind of catamaran or raft that is described by Ulloa. He named the gromp of islauds embracing Natividad, Cerros aud the Benitos, Los Dolures. Neither Ulloa, Vizcaino vor Cabrillo refer to the San Benito Islands.

The San Benito Islands form a group of barren and rocky islands sixteen miles west from Cerros Island. They cover an area of about six miles loy two miles. The westeru or largest island of the group is about one and a "uarter miles long and rises to six hubdrerl aud fifty feet elevation. There is auchorage in ten fathoms of water orer sandy botton, a little to the westward of its sontheast point.

On the sonthwest part of the western islet a Japanese wreck was found by Captain Scammon in 1853. The keel and three or four strakes of the bottom remained. The nails, as well as the wood, provel it to be $J$ apanese; and the indications were that it had been a long time in the watel:

Bahia de San Aavier: by Father Taraval, 1734.

Sebastian Vizcaino Bay. This is the great gulf which has Ceros Island for its westeru limit, the north shore of the great rauge of tho Sien'a Pintada for its sonthern boundary, and the long, low, sandy shores of Scammon's Lagoon, Black Warrior Lagooo, acc, as far north as Playa Haria Bay, for its eastern shores.

In describing the laudiall about Cerros Island this bay was referred to by Ferrelo as that "great gulf" [una ensonatla graule que no paresce tierra], extending to the northeastward fron Point Eugenio, but to which neither he nor Vizcaino gave any name. The latter has given no limit to its eastern shores; he saw them receding, but did not trace them. The frigate reporterl that she could not see the linit of this "great arm of the sea which penetrated the land far to the eastward" (pp. 67,69).

To form this gulf the trend of the coast changes at Point Eugen io from uorthwest and soutbeast on the ocean side to cast ou the gulf side. From that point the shore is high and bold for thirty-three miles to the east; then becomes low and sandy and sweeps twenty-cight miles to the northeast, past the mouth of Scammon's Lagoou to Black Warrior Lagroon; then $t$ wenty-four miles northward past Lagoon 1Head; and finally changes again to high bold shores running northwest for nearly ove hundred miles.

Scammon's Lagoon is the deepest part of this gulf. It is known to extend fifteen miles to the eastward towards the base of the Santa Clara Monntains. The entrance is in latitude $27^{\circ} 5 \mathrm{t}^{\prime}$, and bears E. by N. $\frac{1}{3}$ N., 41 miles from Point Engenio.

Near the entrance to this and the Blick iVarrior Lagoon, the shore-lide is backed by very bigh sand dunes, and drift logs have beon fond amoug these clunes two miles iulaud (1-54). In Scammon's Lagoon Spanish cedar trunks of trees with branches were found by Scammon. They had drifted from the Mexican coast and islands.

Lal Puata de San Engenio, Vizeaino's ehart.

Sierru Pintada, Torruemada.

Point Engenio, latitnde $27^{\circ} 50^{\prime}$

This headland is not described by Cabrillo or Vizeaino, althongh it is a very remarkable landfall, and the southcrn Iomudary of the great Gulf of Sebastian Vizcaino. It is the western extremity of the monntainons penin- 
UNITED STATES COAST AND GEODETIC SURVEY.

CABRILLO.

ULLOA AND VIZCAINAO.

H. Ex, $40-23$ 


\section{DAVIDSON}

sula, thirty-five miles long, and from three to twenty niles broad, which stretches from Table Head towards the northwest. Within seven niles of the Point the monntains aro over 1,100 feet above the sea, and beyond the depression behiud Port San Bartholomè they gradualy rise to nver 3,000 feet. The immediate shores are compact, bold, and forbidding. The prolongation of thes peninsula is exhibited by the islands Natividar, Cerros, and Siu Beuito.

El Puerto de Sinta Ciara, in $30^{\circ}$ "scant," Ferrelo.

La Bahìa de Sav Hipolito, Yizcainn, just nnder latitulle $: 29^{\circ}$ on his chart.

La Playa Maria Bay, latitudo $22055 \%$. The correction to Ferrelo is,- $1005^{\prime}$ "seant," aud the bay lies almost northeast (true), 17 leagnes from the north end of Cerros Islaut.

Playa Maria Bay is formed by an east-northeast sweep of the shore-line for three miles from Maria Point, and then east-southenst for sis miles to Black Point. It is about two and a half miles deep and six miles broad between the two points.

The shores are low, saudy, and barren. At the northeast angle of the hay there is a cone-shaped hill 256 feet high. Immediately belind this hillock, and to the mortheastward, the latest charts place a lagoon, hut the traders assert (1885) that there is no lake and no water here.

There is grood anchorage in the northern part of the bay in six or seven farhoms of water, over saudy bottom, where ressels may lie juotected from the prevailing snmmer winds.

For two or three miles back of the north shore the land is low aud fiat, and then it rises quickly to the great coast barrier which reaches n:arly three thonsand feet elevavation.

1 judge this to be Torquenada's San Hipolito, and not Santa Rosalia Bay tweuty-three miles to the sontheast where there is good anchorage and no fresh water, becanse Vizcaino's Bay of San Cosme y San Damian, which lies fonr leagues to the $n$ orthwest, has a fresh-water lake He lack detailed and accurate livowledge of this region. but it is probable the reporterl lingoou miy hare fresli water in very wet seasons.

San lripolito had aldeady been examined by the Almilantat when separated from the Cajitan and Fragata.

Finsenuda de San Cosme y San Damian, Vizcaino.

Blauco Bay, iu latitude $2 y \circ 04$.

Five miles from Maria Point the coast-line falls lack one and a half miles and forms False Bay. Five learnes from Mlaria Point the shore recedes three miles to the northeastwarl, and forus Blanco Bay, which is a broad hight open to the southwest. Good anchorage may be fonnd here protected from the prevailing coast winds. The sloves are high and rocky, and the coast mountains reach 2,500 feet elevation in ten miles. There is sairl to be no fresh water here.

La Punta del Mal Abrijo, 3010, lerrelo.

Point Canoas, iu latitude $29^{\circ} 25^{\prime}$; correction to l'errelo, $-11^{\circ} 05^{\prime}$. There is a possilhility of its being Bluft' Point, in latitnde $29^{\circ} 34^{\prime}$. Working back from San Geronimo lsland, one of these points nunst be that which Calmrillo intended to resignate as Mal Abrijo.
FERRELO.

They reparted from the isknd of Zedros on Thursday, the tenth day of the said nouth of August, to pursue their voragre, and jroceeded along the shores of the mainland, sailiug in the north. They went this day about ten leagues, anel the following lirday dropped anchor in a port which they called Puerto do Santa Clara; it is a good port. Thes landed and found fonr Indiaus, who fled. This port is thirty degrees seaut; it trends with the island of Zedros, northeast and southrest, aud this coast runs from the port towards the ensenada, northuorthrest aud sonth-southeast. The coast is clean and sonudable; the land is bare and is not rugged. It has plaius and valleys. They were in this port until snuday, the thirteenth of the said montl, on account of fonl winds.
Sunday, the thirteeuth of tho sail wouth, they departed from this port and went sailing along the coast with ligbt winds, auchoring each uight; and the following Tuesday they let go anchor uder a point which forms a cove, which is in thirty and a half degrees; ( ${ }^{4}$ ) it affords very little slelter: they called it Pnuta del Mal Abrijo. 
"And they sailed from this ishand [of Cerros] on the ninth of September [1602] iu search of the Isla de Conizas. But first the Armada sailer towards the mainland, which trended to the nerthwest: and on the eleventh the squadron made the coast, which on their approach the found to be lovel and pleasant, and they saw a bay, to which (p. 69) thes gavo the aame of San Hipolito, and the ships came to anchorin it. * * * They found the country rery fertile, and of a dolightful appearance, and a broal beaten road, leading from the coast to the inland parts. They also found a large Lut, covered with palm leares, and capable of holding conreniently fifty people.

(P. 69) "Four leagnes farther to the northwest of the ensenada of San Hipolito is another which they named La Bahia de San Cosme, y San Damian, which the Almiranta had survesed, while she was in search of the Capitana. It is very well sheltered from the north west winds, ond near the shore on the mainland there is a famous freshwater lake, and the country also is beantiful, fertile. and level." 


\section{DAVIDSON.}

Point Canoas is a sharp perpendieular sand bluff 274 feet high, baeked $3 y$ hills from 700 to 1,200 elevation, and these again backed, at ten miles from the shore, with $n$ range 2, 100 feet above the sea. An anehorage partially proteeted from the coast winds is found under the lee of the poiut in good weather, in five to seven fathoms of water, over saudy bottom, aljout a mile form the shore.

From the point the shore-line runs ten miles eastward, of which the eastern sis uiles has a low shore with a broad plain behind it, according to the ehart of 1873 .

If he anchored deep in the bight betreen Point Canoas and Bluff Point, Cabrillo might bare been abreast a deep arroso laid down on the latest charts.

Vizeaino has an anehorage laid cown just under 300 , but without name.

Cabo del Eugaño, no latitude, Vizeà̀no. See page 184 for the Cabo del Engaño of Ulloa, Cabrillo, and Ferrelo. Bluff Point; latitude $29^{\circ} 34^{\prime}$.

A study of Vizeaìno's narrative fully satisfies ne that be applied this name to the headland which is fifteen or sixteeu miles sontheast of Point San Antonio.

Vizcaìno had stormy weather here; his ships got separated; and he gives the partienlars very clearly. Je says the island of San Geronymo is about eight leagues to the Fest-northrest of Cape Engaño. It is just 25 miles.

Bluff Point is a bold sand point 100 feet high, and lies eighteen and three-quarter miles in a southeasterly uirection from Point San Antonio. The sand bluffs on this part of the coast are backed by moderately ligh hills and in some portions by table-lands that rise from 1,000 to 2,000 feet in elevation. Of these mountains, Sombrero Peak, lying about two miles to the northeast of Bluff Point, is the most conspicuous, and reaches an elevation of 1,963 feet. The chart exhibits a "table land" ten miles in extent, to the northwest of Bluff Point, and about two thousand feet in height. It is ouly about five miles from the shore. This table-land is Las Mesas rle San Cypriano of Vizcaino, in latitude $29^{\circ} 4 \cdot \varkappa^{2}$.

La Bahì de San Franeiseo, Vizeaìno. Jle gives no latitude. It is laid down upon his chart about three learnes to the sontheast of the Isla de San Geronimo, and must be to the southeast of the Point Engaño or San Autunio, and to the northwest of Bluff Point. Abreast Las Miesas there is a great field of kelp stretehing out to twentyfive fathoms of water, anc it is prohablo that inside this kelp, nnder some slight indentation, they found anchurage, and gavo it this name. $\Lambda$ depth of twelve fathoms of water is fond in this kelp four miles from tho shoro over a bottom of sand aud rock. The slight indentation of the shore abont fivo miles southeast of Point Eugaño or San $\Lambda$ tonio is in latitude $29^{\circ} 42^{\prime}$, and under the nol'thwest flank of Las Mesas. The latest charts ro not give any anehorage at this plaee, nor has it any name.

Point San $\Lambda$ tonio, Iatitndo $39^{\circ} 4 \bar{j}^{\prime}$.

This is really the turning point of the coast-line, where it takes a new trencl more to the northward. This is not the Cabo del Engaño of Cabrillo. It is not mentioned ly Vizeano in his narrative and his chart does not indicite it, but unusual proninence is given to the Islancl of

\section{FERRELO.}


(P. 70.) "As the Armada proeecled along the coast they saw many large fires aud smokes niade by the Indians. But the northwest wind blew so violently, and the air was so eold, that the squadron was obliged to run close in with the land, and on the sixteenth they were under some lofty black mountains, on the top of which were large plains. These they called Las Mesas du San Cypriano. To the leeward or sontheast of this Sierra or range of mountains (p. 71) wero some whiteclifts; and on them great uumbers of Indians. * * * However, the next day the weather became fair, with a gentle breeze, by which they recovered what thcy had lost during the storm, and arived of the Mesas, where the land forms a point of the Cape. Here they were again overtaken by a most violent gale from the northwest, with thick reather, *** $*$ and again lost sight of each other (p. 73). The renson for the usual violence of the wind at this Cape, ealled del Engayo, is that the air is there contracted betwixt the eape and the island of Ceniza, which lies about eight leagues distant along the mainlaud to the rest-northwest of Cape Engaño (p. 73), and this island is divided in the middle, forming two steep, lofty, round mountains of equal height. * * * The Capitana aloue * * * eren ventured to donble Cape Engaño.

"And haring to the northwest of Las Mesas cle san CY. priano and the Cabo de el Eegaño (p. 73) feund a good harbor, the General ordered the two ships to stand in for it. Accordingl 5 , in the evening of San Francisco, which was the 3rd of October, they entered the bay, which they called La Bahia de San Francisco (p. 74). In a raneheria they found ouions and goat's horins. The country is level aud frnitful, and by the dung and other indications seems to have a great plenty of cattle and deer. 


\section{DATIDSOY.}

San Geroniuo. Avd I think it highly prohable that it is not the Engaño of Ulloa, wLo may have reached this latitude, and seeing Point Baja beyond and a trific farther to the westward, gave np the ceaseless strnggle be had made against the northwest windis.

It is a hluff point, with a peak 570 feet high, close to the shore, and abont one and a half miles sontheast from the point.

About three miles southeast of the point there is the month of a very renarkable gorge, whieh extends more than a mile inland. Between this gorge and the high peals the Sau liosario River enters the sea.

Ferrelo was nuter the coast between Blnff Point and Point San Antonio.

La Isla de San Bernardo, 30120, Ferrelo.

La Ista de San Gerónymo, Vizcaino.

San Crerúnimo Island, latitncle $29^{\circ} 48^{\prime}$, correction to Ferrelo's latitude, $-4 \cdot 2^{\prime}$.

This isiet lies eight leagnes from Bluff Point, and thirteen leagnes from Point Canoas. It is a league broad ofi Point Sau Autonio. Five miles to the south-sontheast Iies the dangerous Sacramento Reef. To the northward the trend of the shore is north-noththest, and to the southward sontheast by east.

"It is a barren rock, cosered in many places with a unixture of sand and gnawo; three-quarters of a mile loyg audless than a third of a mile broad; with roeky beaches and elift's ton to twenty feet in height. Near the centre is a jeals 1\%\% feet high, and northward of this are two lower ones." * * * "There is anehorage to the eastwarl of the islet in about seven fathoms over sandy botfom, but an meomlortable strell will nsually be felt. A good landing place is found on a small shingle beach, in a slight indentation of the shore-line on the sonflueast side of the islet, at the base of the highest peak."

The present absence of wood may have resulted from fire sprearling over the islet.

Torrquemala is apparently confusen about the Islaul of Cenizals and the Island of San Gerónimo, as it they were two distinct islauls, aud he even mentions the characteristics of each. The explanation is this: The Almirauta, after her separation from the fleet, scarched for the Capitana by going as far back as Cerros Island, and then, not wishing to be again obstructed, made a long tack to seaward (p. 79), when she saw Guadalupe Islant, which she named the Isla do Paxaros, ant from this position she tacked inshore, making the landfall lorth of San Hilario Islaud (Sau Martin Islaud), which ther sals and misealled the Island of Cevizas ( 1.89 ); thence she sailerl in search of the Capitana, and when pear the Bay of the Virgins she saw the Capitana aud Fragata sailing out. "I'his istet, as we shall soon see, is also double heisled. Noreover, it is evident that the fleet had j'revions knowlerlgo of somo island described as Cenizas (cinclcrs, Iava), becanse on their passage to the nort hward they leit C'cros Island to search for it. This knowledgo they must have derived from the voyages of Ullow and Cabxillo, and the ilescription may possibly have referced to Natividad and Cerros Islamds.

On Vizeaino's retnrn voyage he passenl the lbay of Todos santos, and came in siglit of the lsland of San Flilario (San Martin Islard) on the 31 of Felutuary (p. 122) And

\section{FERRELO.}

wind from the west-northwest, and lay to for rest; and the following Friday they proceeded with fair winds and they fonnd themselresoto windward of the Point of Ma] Abrijo six leagues; and so they held on [their course] until the following Satnrday, on the rineteenth of the saịl month,

when they dropped auchor off a small island which is haif a league from the mainland. It may be ten leagues from the Point of Mal Alrijo; it is in thirty aut half degrees; it has a good anehorage ant good shelter; they called it San Bervardo; it cxteuds onc league morth and south. The coast of the mainlaud rum north-northwest and south-southeast, and is a clean eoast. The land withiu is of very good appearance and level, and there are good valleys and some trees, and the rest is barto. They did not find these days a sign of Indians. 
(P. 68.) "On the 9th of September, the squadron left the island of Cerros, to proceed to that of Cenizas. ** "The island of Ceniza which lies about eight lengues westnorthwest from el Cabo de el Engaño [or Bluff Point] (p. 73). (P. 74.) The Iragata also reported that a little fartber [beyond Babia de San Francisco] they found a small island which they called San Gerongmo; and the Genexal ordered some of the sailors to go ashore and take a riew of it. Here they saw prodigious numbers of birds, and much wook.

[On his chart it is named the Isla de San Geronimo.] 


\section{DAVIDSON.}

"after passing the Bay of the Virgins on the 5tb of this month, they made the island Cenizas, which, as wo have already mentioned, had been survejed by the Almiranta. Here the northwest winds incrensing, the ships stood in for the Island of Cerros." This Island of Cenizas is certainly the San Geronymo of October 3d, 1602 (p. 74).

El Cabo del Engaño, 30॰, Ulloa.

El Cabo del Engaño, 31॰ Cabrillo.

La Punta del Engaño, 31०, Ferrelo.

Point Baja, in latitude $29^{\circ} 56^{\prime}$ (on a late chart, Punta

Bajo). The correction to Cabrillo aud Ferrelo is, $-0^{\circ} 64^{\prime}$.

It is eight and a half miles N. by W. $\frac{1}{2} \mathrm{~W}$. from San Geronimo Island, and NW. by N. $\frac{1}{2}$ N., twelve and a half . miles from Poiut San Antonio. Eastward of the point the shore retreats abruptly and forms Rosario Bay, in which safe anchorage may be had in five to six fathoms over sandy bottom, sheltered from the usual coast winds of summer. Punta Baja is a low sand cliff 30 feet high. Behiud it the land rises to 300 and 500 feet in two miles, and to a moustain range of nearly 2,000 feet elevation within ten miles. The shores of Rosario Bay rise in sandy eliff's from 50 to 100 fect high. Off the point and the approaches great fields of kelp extend out in to deep $\pi$ atèr

The coast from Punta Baja runs true north for twentyfonr miles beuce to Point Sau Quentin.

El Pnerto de la Posesion, 31 $\frac{1}{2}$, Fcrrelo.

La Bahì (de las Virgines), Vizcaìuo.

Port San Qnentin in latitude $30^{\circ} 24^{\prime}$; correction to Ferrelo, $-1^{\circ} 06^{\prime}$.

La Punta de las Virgines, Vizcaìno's chart.

Cape San Quentiu, latitude $30^{\circ} 22^{\prime}$.

This eape is twenty-six and three-qnarter miles NW. by N. from Punta Baja, and is the sonthern termination of a varrow peniosula eight miles in length, formed by $\mathrm{a}$ line of five remarkable hills lying north-northwest and sonth-sontheast, and from 324 feet to 1,000 feet eleration. They were aptly named the Five Hummocks by Vancouver.

To the eastward of this peninsula there is low conu-" try, with great lagoons penetrating the laud for several miles. 'The entranco to these lagoons is on the east side of the cape and two miles from its cxtremity. Insicle of the entrance the port is small but aftords perfectly securo anchorage anl protection from all winds. No vessel drawing over twelve feet of water should attempt to enter the port without seuding in a boat to sound the channel, which has two and a quarter fathons of water at low tide.

The village of Sau Quentin lies five or six miles in a northeasterly direction frow the auchorage, at the foot of a range of hills, aud near some salt pouds.

Tebentofi, in his hydrographic description of this part of the coast, says: "The ouly place where fresh water fit to drink is to be found, is the well, excavated by the Russiaus in 1805 , sitnated upon the spit running from the right shore tow ards the Cape San Quentin. 'The soil is of sand and clay, impregnated with salt, aud in

\section{FERRELO}

Sunday, the tweuticth of the said month of Augnst, they departed from the island of San Bernardo, and approacher Pnnta lel Engaño, which is seven leagues from this island, which point is in thirty-one degrees: the coast of the point towards the island trends north northrest, south-southeast; on Punta del Engaño the land is not high, and appears iu itself a goor and level laud; the ridges are bare: we saw nosign of Indians;

and so they continued sailing until the next Mouday following the coast to the north and northeast; a ud about ten leagues from Punta del Engaño they discovered a good port, in which they anchored and took in water and rood: it is in thirty-one aud a balf degrees: it is a port suitable for making any kind of repairs for the ships, lyy placing the latter nuder the lee of the hills.

The following I'uesday the captain, Juan Fodriguez Cabrillo, weut ou shore and took possession of it in the name of His MIajest5 aud of tho most illustrious Señor Don Antonio de IIendoza, aud gave it the name of Puerto de la Posesion. He found a lake which hat three ( $\left.{ }^{3}\right)$ [arms]; and they found sone Indian tishermen, who inmediately fled. Thes took one of them, and, giving bin certain presents, they released him, and he went off. The land in tho iuterior is high and rugged aud has gool valleys, and appears to be a good country, althougl it is bare. They were on shore here until Suuday, the twenty-serenth of sail month, repairing the sails and obtain ing a supply of water; and Thurselay they saw certain smakes and went thero with a boat and found about thirty fishermen, who were friendly, and they brought to the ship it boy and two Indiau women, to whom they gave clothing and presents and let them go; fron whom they could understand nothing by sigus.

The following Friclay, going to take in water, they found at the watering place certain Indians, who were friendrs, and these showed them a pond of water and a salt pit which eontained much, and they said by signs that they had not their habitation there, but in the interior, and that there were many people. "This same chay, in the ercning, fire Indians came to the shore, whom they bronght to the ship, and they appeared intelligent Jndians; aud entering in the ship they took note of the Spaniards who were there and counted them, and wadio sigus that they had seen other men like them, who hat 
On the twentiels of August they fonnd themselves at lil Cabo del Engaño in thirty and one degrees.

\section{ULLOA.}

"They sailed to thu north ward abovo tronty leagues beyond this islaud [of Ceiros], and were then in thirty degrees of north latitude."

He "was driven back" by " the north west wiuds, which contiuned fixed." * * * "Ulloa makle maur attempts to get to the north, but was always forced to return for shelter to the Isla de Cedros. The Santa Agueda, the larger ressel, being a heavy sailer, and in mant of repairs, Captain Ulloa determined to send her back to Lew Spaiu, and to endeavor with the irinidad only to proceed on the proposed discovery. * * * On the 5th of April the two ressels parted, the Sta. Agneda sailing for Now Spain. [Ineidentally this vessel nutes sea weed growing in fifteen fathoms of water, sie.]

"Ulloa, in the Trinidad, endea rored in vain to get farther north. 'The ntmost he reached was to a point of land which he named Cabo del Engaño [the Cape of Deception]. The winds blowiug unceasingly from the northwest, and his provisions being nearly expended, he bent his conrse for New Spain, where lie arrived after an absence of a sear, which was cmployed in this expeditiou."

VIZCAINO.

"A littie beyoud this island (p.7t) [of San Gerouino] there seemed to be a large bay or inlet (p. 75) with a very impetuous current both at the ebb and flood tides: and the General snpposing there might be a large river at the bottom of it, stood in with both ships, in order, if it afforded a good harbor, to wait some days there for the Almiranta, which if not lost, nust pass near the month of it. The teuder stood in first, sounding all the way; but at the month of the estero fonud a bar with only thrce tathoms of water at low tide, so that the Capitana did not think it adrisable to ventire in; bot the tender sailed orer the bar, aud foumd a good harlor. * * * They found near the coast a grent number of naked Indians, fishing iu eanoes made of thick aud pliable thags whieh grow in fresh water * * * And whoshower them several wells of very good water, *** which were in a thick copse of willows aud osiers intemised. * * * The Indians also intimater bs sigus that ny iu the country there were great numbers of people clother, who bacl beards, and that they also had fire-arns.

"The Capitana awd Fragata having staid in this bay tho time proposed, the General gave orders for putting to sea, in order to look ont for the Ahniranta; aceordingly she got under sail on the 24 th of October; but as they were stauding out of the bay they saw the $\Lambda$ lmiranta, whieb gave them the greatest joy, not having secn her for twenty-eight days, and had now given her over for lost" (p. 78).

[On his chart Vizcaìno loeates the Indiau village; and makes two anehorages in the open bay.] 


\section{DAVIDSON.}

places uvergrowu with a hard prickly plant, slelteríg numbers of soakes : on the beacl turtles atud anphibians are eonstantly sumuing themselves, as well as seaelephants, sea-lions, and sometimes fur senls. Thero are very few hirds."

From Port San Quentill the eoast treuds east wardly for seven or eight miles aud then turns to the southward, forwing tho open bay of San Qnentin. The water is shoal for several uniles oft shore, and a long swell will usnally be fouth rolling iv, making it a.o uncomfortable anchorage. The north aud east shore of the bay is a low sand beach, with the eastern hills rising to three huudred feet bigh a short distauce inland, aud these baeked by a monntain range reachiug fron 1,500 to 4,000 feet.

In his narrative Vizcaino does not give any name to this " grande Bahia o Ensenala" (p.74), but ou page 80 , when speaking of the Almiranta comiug itz sight, he refers to it as la Bahia de las Virgines:

La lsla de San Angustin, Ferrelo. The gives no latitude and no distanee sailed lirom Cape Sau Quentin.

La Isla de Cenizas, Vizeaioo, ly the Aluniranta (1.50).

La Isla de San Hilario, Vizeaino, by the Capitana (p. $₫ 0)$.

San Martin Islaud, latitude:30 $29^{\prime}$.

On the chart of Vizeaino it is laid down just outside Cape San Quentin, lnt without naple. Ou his retnru to New Spain, in Febmary, 1603, he reached the wells of the Bay of Todos Santos, \&c., and contiuning southward eame in sight of the island of San Hilario.

It is in latitude $30^{\circ} 29^{\prime}$, lies three miles oft the coast, and is nearly ten miles northrest from the eape.

"The islaud is nearly eirenlar in form, having its great. est diameter (one and a balf uiles) in au east and west direetion. There are two remarkable peaks near the eenter. The western, whieh is 497 feet high, is an extinct volcano having a crater at its summit 350 feet in cliameter and 40 feet cleep. The island is quite harren, prodneing nothing lont the prickly pear and a few stunterl bushes, that grow among the loose masses of lavil.

"There is good anchorage on the southerst sicle of the island, off a small lagoon whieh has eommunieation with the sea at half tide; and aneborage nuy be found anywhere on the northeast side. The liest place to anchor in is Hassler Cove, a sngg little hight on the eastern sicle of the island, proteeted on all sides exeept the north. Anehor in seven to nine fathoms with the northeru end of tho natnral breakwater that forms the east sille of the cove, bearing S. $57 \frac{1}{2} \circ$ E. true. The islaul is surrounder by detaehed roeks and kelp; and great numbers of seal and sea fowl resort to it, particularly to the slores of the eove and the lagoon" (p. 8).

Torquemarla says that the Island Cenizas is clivided in the middle, making two high monutains. Ferrelo dees not mention on which side of the island the drift timber was found, but ovidently on the east, where he anehored. [See menorandum about tho Spanish cerlar found at Scunmou's Lagoou. ]

San lamon Bay, iatitude $30^{\circ} 49^{\prime}$.

lor tweuty-one miles north of San Martiu lslamb the coast-line runs noarly true north ilud south, and then forms the broad bight known as San Ramou lia y or Virgins Bay. Thenee the slure of saull dunes rnus nortliwest to the

\section{FERRELO.}

beards, and who brought dogs and eross-bows and swords. The Indians eamesmeared with a white bitumen on the thighs and body and arms, and they had the bitumen applied in the manner of slashes, so that they appeared liko men in slashed domblets aurl hose; aud they made sigms that tive days' jouruey thence were the Spaniards. And they made signs that there were many Indians, and that they had much maize aul many parrots. They eame covered with deer skins, and somo had the deer skins dressed in the manner in which the Mexicans dress the skius which they eatry in the entters. This is an arlvancerl and well-tisposed people. They carry hows and alrows like these of New Spain, the arrows tipped with flints. The Captain gave them a letter, whieh they shonld earry to the Spaniarts who they sairl were in the interior.

They departed from this Puerto de la Posesion Sunday, the trienty-seventh of the said month of Augnst, and sailing on their course fonnd an island tro leagnes trom the mainland; it is uninlabited; there is a good port in it; they gave it the name of San Angustin ; it menenres two leagues in ciremmference; and so they held on along the coast with light winds, working to windward, until the following Weduestay, the thirtieth of said month, whieh gave them mueh wind from the northwest, whieh compelled them to put into the island of Sau Augustiu. In 1 his island they found some sign of people, and two cow-horns, and very large trees whieh the sea had east there, which had more than sixty feet in length, and were of such thiekness that tro men conld not enliraee one of them; these appeared to be cypresses, and there were eedars. There was a large quantity of this wood; it contains nothing else. If a good port, it is not a valuable island they treve at this island until the following Sunlay.

Ou Sunday, the third day of September, they departed from the said island of San Angnstin, and proeecded, sailing on their eourse, and $t$ he following Monday they dropped anchor about seven leagues distant on the windward shore, on a eoast running north and south ; and then they 
When the Almiranta stood inshore from the islaut of Paxaros or Guadalupe she made the coast just north of the island of San Martin, and "they saw the island of Ceniza, that was left bebind them (p. $\varepsilon 0)$; that those of the Capitana lad not seen; and prosecutiug the search for the Capitana and the Fragata; and coming in to tho Bahì de las Virgines, they saw the Capitana and tender sailing out to sea: * * * and the General gave orders to continuo their course to the first barbor they shonld find. Accordingly they passed near a small island close to tho mainland, which thej called San Filario *** (p.80). 


\section{DAVIDSON.}

bay under Capo Colnett, to neither of whieh does Ferrelo refer, unless he means the bay under Cape Colnett when he says he anelored in the Ensenada which the island forms. The eoast henee rnns eighteen miles true nortl. There is a broad valley northward of Cape Colnett and then jagged monntains.

For fifteen miles southeast of Cape Colnett the kelp field is very dense in thirteen fathorns of water. On the other hand, he may have anehored in the broad indentation sixteen miles nortb (true) from Cape Colnott, ofi the mouth of the San Vicente River. Five miles off the shore sonndings aro had in thirteen fathoms of water. A fer miles in the interior the moutains attain an elevation of 1,500 to 2,000 feet. At eight or ten miles inland is the old Mission of Sau Vicente.

Cabo de San Simon y Jndas, Vizeaino's ehart.

Cape Colnett, in latiturle $30^{\circ} 59^{\prime}$.

La Babia de San Simor y Judis, Vizciano (pp. 81, 81). Colnett Bay.

Cape Colnett is a remarkable headlasd. Its store ontline is semieirenlar, with perpentlienlar eliffs, from 150 to 350 feet high, of a very dark-eolored roek whieh forms tho upper horizontal layer or stratum, based on a light sandstone. The eoast retains the same general appearanee for ten miles to the northrard of the eape. The eastern shore of the eape treads north and east ward for two and a half miles, forming Colnett Bay, wnere good awehorage may be found abreast a remarkable gorge in from six to viue fathoms of water over a saudy bottom. Ten to fifteen mi'es southwarl of tho eape tho eoast sweeps around to the sonthward, forming what is ealled on the charts San Ramon Bay, as already mentioned. Ten miles belind Cape Colnett the mountains rise to I,500 and 2,000 feet elevation. Neither Cabrillo nor Ferre!o refers to this notable headland to the bay.

This is the first time that Ferrelo mentions eurrents from the north ward.

El Cabo de San Mlartin, 3270, Ferrelo.

Cape San Tomas, or Point Santo 1 omas; la:imde $31^{\circ}$ $53^{\prime}$; eorreetion to Ferrelo, $-0 \circ 5 i^{\prime}$.

Ferrelo's deseription means a narrow promontory or sharp eape formed by a spur or ridge of the mountains projeeting from the interior and euding in a high point.

Vizeaino makes no mention of this eape in his narrative; but he has the projecting point on his ehart, aucl behind it the logend "monntainons."

"The point lies twelve miles S. $14^{\circ} \mathrm{E}$. from Bauda Point. The eoast-line between then is ereseent-like, high and preeipitous, with deep water elose iushore, and $\mathrm{nn}$ merons letaebed roeks. The point itself is low anel roeky, rising abruptly to a height of 395 feet, whero it unites with the eoast mountains, which attain, at fre or six uniles inland, an elevation of 4,520 feet. * * * Half a mile to the southmard of the point the coast makes a sharp turn to the eastward, forming a small bight, where good anehorage may be fonvel one quarter of a mite from shore, in five to six finthoms of water, over sandy bottow, sheltered frou the prevailing eoast winds. A streau ruming through a teep cañala opens on the beach two miles sont heast of the anclorage; a roal leads from abreast this anchorage to tho mouth of this stream, and thence to the old Mission of Sinto Tomns, situated sixteen.milos
FLRRELO.

eoutinued their eourse and were sailing with ficir weather, on a coast runuing uortl and south, nutil Thnrslay, the seventh day of tho said month of September, when they cast anehor in a cove whieh the lant forms; and here ends the coast, whieh runs worth and south and tnrns to the northwest. Behind this eovo there is a large valley, and the land is level on the coast, and within are high ranges, and rough land good in appearanee. All the coast is bold rith a smooth bottom, as at half a league from land they were at auchor in ten fathoms; here there is muel vegetation on the water.

On the Friday following, on the eighth of the said month, thes beld on with light wiuds, working to wiudward, and they fouvd here eontrary ourrevts;

they dropperi anchor miler a point whieh forms a eape, and affurds a good shelter from the west-northwest; they gave it the pame of Cabo le San Nartin; where the laud terminates on both sides; aud here also terminates a ehain of high mountains that are be cond in the distanee, and exd by other smaller sierras. There is a large valiey and many others; in appearanee it is good luxd; it is in thirty-two and a balf degrees, and is a elean port and soundable; it tremls with the islaud of San Angustin, north and sontb.

Peing at this Cabo de San Martio, they went on shore for water, aud fonnd a small lagoon with iresh water, where they proenred water, and at this watering-plaee came forty Iudians with their bows and arrows; they eonld not understand ench other; they eame naked; they brought roasted agaves to oat and fish; this is an alvaneed raee; here thoy took possession; they were at this cape until the following Monday. 
CABRILLO.
ULLOA AND VIZCAÎNO.

(P. 80.) "And ranging along the coast [uorthward from Isla de San Hilario] they came in sight of a large bay, which the General erdered the tender to somud and surrey; and they found it afiorded a rery good shelter against the northwest wind (p.81), and there were many Indians, and going further nerth about two leagues they were overtaken by a strong gale at northwest which obliged them to pnt back inte the sail bay; and it being the annirexsary of the glorions Apostles Saint Simen aud San Judas, October 28 th, they gave that name to the bay. Here the General ordered the $\Lambda$ 'minanta to take in rood and water. *** Near the shore they found a considerab'e number of Indians, who were alert and conrgigeous" (p. 81). [They had a fight with the Indians, * * * and left the bay on the first of November.] 


\section{DAVIDSON.}

inland, iu a very fertile valley. $\Lambda$ sualler stream opens directly opposite the ancherage."

In 1873 , when passing this point, we made the follewing note which may explain Ferrele's peculiar expression, "As seen from the nerthwest, the point of Solitaries shows vertical dykes" (with illustrations).

The ancherage is called "Sheltered Ceve" in the Coast Survey Chart of $\mathbf{1 8 5} 4$

El Cabo de la Cruz; $33^{\circ}$ Calurillo.

El Cabo de Cruz; $33^{\circ}$ Ferrelo.

Grajere Point, in latitude $31^{\circ} 45^{\prime}$.

Banda Poiut, on some eluarts.

Correction to Cabrillo and Ferrelo, $-1 \circ 15$.

Las Islas de Todes Santes.

La Eusenada de Terles las Sautos; Vizcaìue (1. 121).

Todos Santos Bay.

Ferrelo does not describe this great bay as a whele, but in embarrassing lletails; and ou acconut of adverse winds his estimates of distances are very erroneons. He barely mentions passing a small islimn, which must be Tedos Santos Island.

Grajero Poiut is a vers bolk, narrow heal, projecting five miles in to the sen to the west-northwestward, and increases in wilth from a quarter of a mile to twe miles. Near the extreme point the height is 1,273 fcet; and iu three and a half miles frem the coast-line, between this eape aud Point Sauto Temas the mountains rise to 3,563 feet. The sides of the cape are preeipiters aud slope both ways (N. NE. and S. SIV.).

The Todos Santos Islands are on the prelengation of the cape aud distant three miles therefrom. Their combined length is two miles, and the width half a mile. The seutheast islet rises 374 feet, and the northwest islet abeut tio fect. They lie about the middle of the entrance to the bay, which is nive miles broad by as many deep. In the sontheast part of the bay there is a broad saud beach behind which lies a lagoon recej ving the waters of twe small streams. Vizcaine iudicates this lew shere by a discontiuned Jine. In the northeast part of the bay is the Ensenala ancherage, and under the verthwest cape, called San Miguel, is the anchorage abreast the Arrege Carmen. Very high mountaius surround the bay. A farerable wind induced Vizeaino to postpone the snrrey of the bay until his return voyage, when lie was unable to carry eut his plan.

El Puerte de San Nateo, 337

This "port" may be the preseut Lnsenala ancherage in the northeast part of Torlos Sautos Bay, where his description suits very well; he sery probably passed outside the Tedos Sautos Islets to get there. It is well sheltered frem all winds but the southwest, and he romld have to get water by digging er from water-poels filled by the early raius. It is euly nine miles in a direet line from bis Cabo de Cruz. It is in latitude $31^{\circ} 51^{\prime}$, and the correction to Ferrele's latitude would be, $-1^{\circ} 29^{\prime}$. If he passed ontside the islets it is a possibility that he was nnder Cape San Mignel or Sausal Point, which forms the northwestern limit of Todes Santos Bay, and lies six and a half miles from the Eusenada a nehorage. The clift's are bold and high, and he conld have gotten $\pi$ ater from the Arrego Cumen, but he wonld have hecu exposed to the beary swell from seatrand.
FERRELO

Monday, on the eleventl of said month, they departed fren Cabo de San DIartin and sailed about four leagues on in coast runving from north-nertheast te senth-senthwest, (5) and thence the eoast turns to the nerthwest. The land is lefty and bare; and the day followiug they sailed also with adverse wiuds about four leagnes on a coast. rumning from northwest to sentheast. On the laud there are high and broken sierras; and the following Thursday they dropped anehor at about three leagues in advance at a point which projects sharply into tho sea; they called it Cabo te Cruz; is is in thirty-threo degrees; there is uo water nor wood, ner dis they fiud any sigus of Indians.

ITaviug departed from Cabo de Cruz, they found themselves the following Satnrday two leagnes from Calo de Cruz on aceount of the lead winds on a ceast from northuerth-west to sonth-sentheast, and nuder the shore they saw Indinns in some very small canoes. The land is very ligh and bare and dry. All the land from the extrenity of California to this place is sandy like the sea-bencl. Here begins land ol anether character, as it is a country of beatiful regetation and better appearance, like orcharis.

Snndiy, t he seventeeuth of the said unth, they set sail to pursue their royage, and abent six leagues from Caloo de Cruz thes fonud a geod port well enclosed, and to arripo there they passed by a swall psland which is near the mainlanel. In this port they obtained watcr, and there arc moves resembling silk cotton trees [eeybas], except that it is liard wood. They found thick and tall trees which the sea throws ashore. This port was called San Mateo. It is a geed country in appearance. There are large cabins, and the herbage like that of Spain, and the land is high and rugger. They saw herds of animals like flocks of sheep, which went toget her hy the humdret or more, which resembled in appearance avd movejuent Pernvian shee $]$, and with leng weel. They have small herns of a span in length as thick as the thumb, and the tail is lorual and ronnd and of the length of a palm. It is in thirty-three and ope-third degrees. They took pos- 
CABRILIO

On the fourteenth of September they cane io anchor at a cape, which they ealled de la Cruz; land precipitous, high, and barrea, which is in thirty and three degrees.
ULLOA AND YIZCAINO.

"The squadron having left the bay of St. Simon and St. Jude (p. 84), and eontimuing their royage against the wind, and against the curreuts, they came very near to a great bay nearly surrounded by lofty menntains; and by the Lreaking of the sea near the harbor, it appenred that it was an arm of the sea or the mouth of a river. In the - west part of the bay, about two leagues distant, there are two islands which they eall Torlos Santos The terder lueing ortered in, the Almiranta followed her; but the Capitana, as night was coning on, sloed off to sea; and the others, that they might not be separated from her, also put baek. This happened on tho 5 th of November, aud the vext morning it was agreed to stand again into the bay and take a plainer view of it, but a favorablo breeze slringing np and the General thinking it most adrisable to take advintage of it, and refer the surver to their retnirn, they continued their course."

[Abont the end of Jannary, 1603, Vizeaìo was leturuing to La Paz for snecor (p. 121); many of hiserew being dead from scurry aud ouly three or four remaining fit to navigate his ship. The wiuds were light and he made but slow progress, hut he carried the ships to the springs or wells which he had previously found in the deepest part of the Ensenada de Todos los Santos.

Under these circumstances his description is very neeagre.] 


\section{D.IVIDSON.}

Neither the Coast Pilot nor the chart notes iny anchorage, althongh it is reported that schooners bavo recently anehored here.

Cape San Miguel lies nino miles truc north from the Southern Cape of Todos Sautos Bay, and is in latitude $31^{\circ} 33 y^{\prime}$. This wonld give a correetion to Ferrelo of $-1^{\circ} 30 \%$. He was in the region of the antelope, which were still ramning in large herds around San Diego Bay in $\mathbf{1} 8 \mathbf{3 1}$.

There is a remarkable valley opening on the coast in $32^{\circ} 06^{\prime}$. It exhibits several marked terraces reaching back and up to a great height above the sea.

Cabrillo must have been near Descanso Bay in latitnde $32^{\circ} 16^{\prime}$, but the distance is only twelve leagnes.

Las Islas Desiertas, $34^{\circ}$, Ferrelo.

Las Islas de los Coronados, Vizeaino (page 85).

Las Islas de Sau Martin, ehart of Vizeaino.

Los Coronados Islands, in latitnde $32025^{\prime}$. Correction to Ferrelo's latitude, $-1^{\circ} 35^{\prime}$.

This is a group of four or five rocky aud desolate islets. There are two unain islets and thres smaller masses of rocks. The largest islet is about soven miles from the coast-line, and the others stretch to the northwest for four or five miles. The largest is two miles long loy half a mile wide; it is weonge-shaped, and at its highest peak attains an elevation of 674 feet. On the west and nortliwest sides lie two barren roeks fifty feet high. The northwestern islet is a barren roek seven-tenths of a mile iu extent and 350 feet high. A fair anchorage may be had in eight fathoms of water over saudy bottom, on the east side of the islet, north ward of its middle.

Koll sajs: "There is little dombt that the "Dolores' mentioned by Taraval were the Coronados Islands"! We have already show that Taraval linded on Natividad and Cerros Islands.

La Mesa de la Cena, Vizcaino's chart.

La Mlesa Redonda of the native Californiaus.

Table Monutain, in latitude $32^{\circ} 20^{\prime} 05^{\prime \prime}$, longitnde 110 $54^{\prime} 17^{\prime \prime}$.

This is a notable mountain, especially as a laudfall to the uavigator; and Vancouver gives a eharacteristic view of it. It lies about sereu miles inside the shore of Descanso Bay. As seen from every side it is flit topped, and the top vearly circular. The surfacc of this takle is covered with singular fragments of rock. The diameter of the flat top is 1,600 yards, aud irs bright above the sea is 2,244 feet; so that it is visible at fifty miles from seaward. A few miles to the sontheast of this monntain there is auother marked nountain of three sharp peaks risiug 400 to 500 feet ligher than Table Monutain. It seems chirious that Cabrillo rid not mention these monutains.

THE COAST OF AJTA CALITORNIA.

Ei Pucrto de San Mignel, $34 \frac{1}{3}$, Ferrelo.

lil Puerto de San Diego, Vizeatino.

El Puerto Bueno de San Diego, Vizaluo's chart.

San Diego Bay. The light-honse near the extrenity. of Point Loma is ix latitude $822^{\circ} 40^{\prime}$. Correction to $\mathrm{F}^{\prime} \mathrm{cr}^{\prime}$ $r e l 0,-1040^{\prime}$.

El binen Pnsto, Vizenìn.

Filse bay:

\section{FERRELO.}

session of it. They were in this port until the following Saturdar.

Saturday, the trenty-third of the said month, "they departet from the said port of Sun Mateo and sailed. along the coast until the following Monday, in which time they mado about eighteen leagnes. They saw very beautiful valleys aud groves, and il comtiy fat and rongh, and they did not seo Iudians.

On the Tuestay and Wellneslay following they sailed along the canst about eight leagues and passed by sotne threo unimhabited islands. One of them is larger than the others, aud extends two entire leagues, and forms a shelter from the west winds. They are three leagnes from the mainland; they are in thirty-fonr degrees. This dar they saw on the land great signal smokes. It is a grood land in appearance, and there are great valleys, and in the interior there are bigh sierras. They called them Las Islas Desiertas.

'The 'Thurslay following they proceeder about six leagues along a coast lumning north-nortiwest and discovered a port eneloser and very goon, to which they gave the name of Sin Mignel. It is in thirty-iour ansl one-third degrees; and after auchoring in it they went on shore, which hat people, three of whom remained anul all the othors thei. To those they gave some presents; and they sad by signs that in the interior had prassed 
"After sulling a few leagnes, the wind again shifted to the northwest, but they kept coasting along the shore, and rere amused by the smokes and fires made by the Indians all along the Strand as an invitation to the ships to send their people ashore. The eountry appeared very beautiful, and level, and pleasaut. At the distanee of six leagnes from the inainland, they fell in with four is]ands, to which they gave the name of Los Coronados ( $P$. 84); the two smaller appear like sugar-loaves, the other two somewhat larger."

[On his chart he names them Las Islas de San Martin, and has a anchorage on the north side of the largest.]

LVizcaino's chart places tho "Mesa de la Cena" near the coast-line to the southward of the Coronados. It furnishes the only attempt at haehuring on Burney's copy of his chart and therefore must hare impressed the cosmographer. 7

"To the north of these islands [Los Coronados] (p. 85), on the mainland is a famous harbor which was named the Puerto de San Diego, which the squadron entered at seven in the evening of San Martin on the tenth of Norember. The day following the General ordered sereral persons to survey a hill (moute) [La Loma] which afforded proteetion to this port from northwest wiuds. * * * On this hill ther found tall and straight oaks, and other 


\section{DAVIDSON.}

La Isia de Areua.

The Peninsula. "The Island" is the low sands, chaparral-copered peninsula, forming the rest shore of the hay and crowling so elose to Ballast Point nnder Punta de la Loma as $t$. form the ileep uarrow channel between the bay and the sea. It is not over six feet ahore the level of the sea, and in 1550 mas localls known as "Tho Island," and now linown as the "Peniusula."

Nest to that of Sin Francisco, no harbor on the Pacific coast of the Uuited States approaches in excellenco the Bay of Sau Diego. It is readily distigguished by the notable landmark of Point Loma, in latitnde $32^{\circ} 39^{\prime}$, is easily approached on account of the absonce of ontlyiug dangers, and a clepth of twenty-two feet of water cau bo carried over the bar. This bar has not changed in depth or position sinee the time of Vazconver.

Vessels approaching San Diego Bay make the ridge of Point Loma as a long fat-topped island; when about twent 5 -fire miles distant. This appearance is occasioned hy the bay to the sour west, by the low land to the northeast, and by the Puerto Falso at the north.

The bay is a long curring boly of water abont twelvo miles in length, aul from oue-half to ten miles in width. For the first six or seven miles from the entrance there is a fino hroad channel. carrying four to eight fathoms of water. The southeru end of the bay is oceupied by very extensive flats, throngh which a ehannel with twents to trelve feet of water is found. Between the bas and the ocean there is a narrow strip of sand dunes and very low ground.

When inside the entrance of the bay, a vessel is sheltered from evers wiud, aud the holding gronnd is good.

When we first visitel tho bay, in 1851, there was no sign of tho trees mentioned ly Tizenino, nor did the Spanish population have any traditions about the.11. His deseription of "el moute" applies with great directness to La Loma.

Kohl blunders very ladly about Tarival's " Babia do San Xavier," aul says that "probably it is the small hay nor lnown as San Diego liarbor." IVe hare shown that it was the great gulf of Sebastian Vizcaino lsing eastward of Cerros Island.

Ensegada (de Sauta Callalina), Vizeaino.

Sau Pedro Bas, latitude $33^{\circ} 43^{\prime}$.

To Vizeaino tbis great hight cmbraced the low country north and east of San Pedro Bay, which laud he did not see. Ou his chart he places Sauta Catalina Isladel broad oft the Bas of San Pedro.

Kohl thiuks that San Pelsu Bay is the Baia de Fumos of Cabrille, but we will show that it is Santa Monica Bar.

La Isla de San SaIvador, Ferrelo.

La Isla do Senta Cahbalina, Vizcaino.

Santa Catalina lsland, in latitude $33^{\circ} 26^{\prime}{ }^{\prime}$, at Istbmus Cove.

"lo jstand is ejghteen miles from the mainland at San Pedro and trenty-tlirce aud a half miles from Point Lasuen.

La Isla de la Vittoria, Terrelo.

San Clemente Island; the latitucle of the southeast hearl is $32049^{\prime}$.

Thuse islands were namel after the ships; the fornser

\section{FERRELO.}

people like the Spaniards. They mauifested much fear. This samo day at night tuey weut on sbore from the ships to fish with a net, and it appears that there were bere some Iadians, and they began to discharge alrows aud wounded three men.

The next lay, in tho morning, they entered fartier: within tho harbor, which is large, witb the boat, and they brought atray two boys, who understood nothing hy sigus, and thes gare them loth shirts, and immediately sent them arvar.

Aud the following day; in the morning, there came to the ship three finll-grown Indiaus, and by signs they saic that there ncre travelling in the interior ken like us, with beards, and elothed and armed like tho:e of the ships, and they mado sigus that they carricl cross-bow and sworis, and malc gestures with tho right arm, as if they wero throwing lances, and went running in a posture as if ricling on horsebaek, and malosigos that they linlled mauy of the native Indians, and that for this they were afraid. This peoule are woll-disposed and arivunced; they go covered with the skius of aumals. Being in this port, there passen a very great tempest, but on account of the barbor being good, they suffered nothing. It was a violentstorm from the rest-southwest and sonth-southrest. This is the first storm which they luave experienced. They were in this port until the following Tuesda.. - Here Christians were called Guacamal.

The following Thesdas, on the third day of the montl of October, they departed from this port of San Miguel, and Wednesday and Thursday and Friday they procceded on their conrse, about eighteen leagnes along the coast, on which they saw many valleys and much level ground, and many large smotes, and, in the interior, mountains.

TLey were at dust near some islands, which are about seven leagnes from the mainland, and beculse the wind had died ont they conkl not reach theu this night.

Saturday, the seventh das of tho month of Oetober, ther. arrived at the islands at ilisbreat, mbich they named San Salvador and La Vittoria, and they auchored off one of them, and they rent with the loat ou shore to see if people were there, and as tho boat approaebed, a great number of Indiaus issned trom anong tho bnslies and prass, yelling amd. daucing and malsing signg that ther sbonld cone ashore; and thes saw that the women wow 
trees; some shrubs resembling rosemary, and a great variety of fragrant and wholesome plants. The top of this hill commanded a riew of the whole harbor which appeared very great and very commodious, and well sheltered from erery wiud (p. 86). The hill borders this harbor on the northwest and is about three leagnes in length, aud a half a league in brearth. And to the northrvest of this hill is another good harbor. * * * They obtained there water from a saudy beach or a-little island ot sauk, where they dug deep trenches, in which, during the flood the water was fresh and good; but on the elsh salt. * * * Most of the Indians painted or besmeared with black and white; and their heads were loaded with feathers. *** They signified by sigus that a certain people nip the country had beards and were clothed like the Spaniards (p. 8s); and by their dress, complexions, and customs seemed to be of the same conutry with tho visitors.

"In this har'bor the is a great variety of tish, as ojsters, mussels, lobsters, soles, Sro, and the cumntry abounded in game. " $*$ * They were highly delighted with the milduess of the climate, aud the gooduess of the soil. * * *

"Everything being completed, * * * they left this place on the twentieth of November (p. 89).

"They Lad no soover left San Diego, than tho northwest wiud commenced to blow (p. 89). Little by little, however, the ships advanced, aud eame in sight of a great gnlf, where the neighboring country presented a very pleasant appearance. Aud as they proceeded they saw also the snoke of large fires which the Indians had kiualed, to indnce the ships to pat in there. But on approaching the coast, found no shelter from the northwest wind; they therefore continned their course, aud a few leagues further diseovered (p.90) a great island abont twelve leagnes from the mainland, and for the day of its discovery, they called it the Isla de Santa Cathalina. On . the 28th of November the slips came close in with it, and from thence had sight of a much larger one lying to the sonthrest of Santa Cathalina. They, however, thonght proper not to survey it till their return (p. 90). [Theu follows a long description of the inhabitants, \&e.]

(P.94) "This island, like nust of those adjaeent, is very popnlous. * * * Thisisland has several good harbors, abundanee of fine fish, esperially large and good sar- 


\section{DAVIDSON.}

after the liag-ship, the Capitana, and the latter after the tevder, tho Almiranta.

These two islands are lirrye, very high, and visible far out at sea. 1 have seen the former from the ridge of Point Loma.

Sauta Catalina lslaach is eighteen niles loug, with an extreme breadth ot seven miles, aud an average breadth of four miles. Its geveral direction is W. by N. $\frac{8}{4}$ N., magnetie. It rises to 2,110 fcet abovo the sea, and is visiblo at a distance of fifty-three miles. It is very rugged, covererl largely with deuse chaparral, and is nearly divided into two islands towards the western end.

Sau Clemeute Island is also eighteen miles Joug, and not over three and a half miles broad; it rises to 1,964 feet clevation, and is visible at a distance of fifty iniles. It lies nearly parallel with Catalina, and directly sonth ; its north poivt is only ninetecn miles from the nearest part of Cataliua.

Neither islaud has been iuhalited by ludians since the country has been settled by Americaus, and the sigus of former populations are much less than on Sunta Rosa and San Miguel. For further descriptions see Davilson's Coast Pilot.

Ferrelo ovidently anchored off tho north side of Santa Catalina lsland.

Vizeaino does not mention Sau Clemente by name, but descrilues it as a larger islaad lying to the sonthrest, and to be surveyed on the return of the expedition from the north. He has not placed it on his chart.

On his plan of Catalina Island he elearly iudicates the locality of the great depression; and a small circle denotes the position of the so-called Temple to the San, \&c.

La Bahia de los Funos, $35^{\circ}$, Ferrelo.

La Bahia de las Fuegos, Ferrelo.

La Bahia Ona, a corruption of La Balloua, a racho borlering this bay.

Santa Honica Bay, namerl from the Sierra Santa Monica. Latitude of Point Dume on the northern shore of the bay $34^{\circ} 00^{\prime}$; correction to Fcriele, $-1^{\circ} 00^{\prime}$.

I feel sure that he made the laud of this bay near Point Dume, where there is shelter, and where there were large rancherias of the Indiaus to a very late date.

Vizcaino does not reution this bay, but it is plaiuly indicated en his chart, as well as the cape formed by Sar Pedro Hill, 1,475 feet elevation.

Ferrelo does not mention San Pedro Bay, but Vizcaino calls it au Eusenada, embracing Santa Catalina Island; and his chart gives it great breadth, and notes the rocky islet called Deadman's Island. This islet is the El Morro of the later Spavish charts.

This part of the coast is sharply backed on the uorth by the almost inaccessible monntains of the Sierra Sauta Mouica. 'To this day they may be said to have no trails throngh them.

Laguna Mrgin, latitucle $34^{\complement} 05^{\prime}$.

'This is a moderately large estero under the northwesterly coast termination of the Sierra Santa Monica, where it crowils over the broad low plains of the Sauta Clara Valley. There is a good anchorage off the mouth of the estero. Sce 'Daridson's Coast Pilot of Califoruia, Oregon, aml Washington.'

\section{FERRELO.}

ruuning away, and from the boats they made sigus that they shonld have no fear, and immediately they assumed confidence aud laid on the grouud their bows aud arrors, and they launched a good canoe in tho water, which held eight or ten Indians, and they came to the ships. They gave them beads and little presents, with which they wero delighted, aud they presently went away. The Spauiards afterwards went ashore and were very secure, they and the Indian women aud all. Here as old Indian made signs to them that on the mainlaud men were jonrneying, elothed and with beards like the Spaniards. They were in this island only until noou.

The following Sunday, on the eighth of the said wonth, they came near the mainlaud in a great bay which they named la Bahia de los Fumos; on account of the numerons smokes which they saw around it. Here they held iuterconrse with some Indians, whom they took io a cauoe, who made signs that towards the north were Spaniards like them. This bay is in thirty-five degrees, and is a good harbor, and the country is good, with many valleys aud plains and trees.

The following Monday, on the niuth day of the said month of October, they departed from la Bahia de los Fuegos, aud proceeded this day about six leagnes, and anchored at il large inlet, 
CABRILLO.

ZLLOA AND VIZCAINO.

dines. * * * The sea wolves serre the Indiaus both for fool and clothiug. * * * After taking a snrvey of several parts of this Island, the squadron left it on the third of December, 1602. 


\section{DATIDSON.}

It is fifteen miles west of Point Dume. From Mugu to San Buenaventura the coast-liue is nineteen milos, and the last eight miles ruus morthwest. This is the only coast-line in this section with this direction and with such a rell-marked valley.

Los Pueblos de las Canoas, 3ī̌

El Pueblo de las Cavoas, $35 \frac{1}{3}$, Ferrelo. ("Which is called Xucu.") Ferrelo, page 84.

San Buenaventura, in latitnde $34^{\circ} 1 \gamma^{\prime}$; correction to Ferrelo, $-1^{\circ} 03^{\prime}$.

San Buenaventura lies iuder the seaward face of the mountains, at the extrome western eilge of the broad, low, flat valley of Sauta Clara. The Sauta Clara River empties into the ocean four or five miles eastwardly of San Buenaventura, while on the immediate rest empties the San Buenaventura River, affer coming tbrengh a smaller and narrow valley among the mountains. The wood, fresh water, open bay, plains on one side and river on the other wonid make this a favorable location for a large village. Ferrelo's description is rery satisfactory, and it will not suit any other locality in this inmediate I'egrion.

Yizcaino sailed past this part of the coast witb favorable wiuds, and did not anchor anjwbere in the archipelago, except at Santa Catalina; but be notes the projectiug shore-line at Point Hueneme, and to the west of it lays down on his chart a large "fresh-water, river," which may be either the Santa Clara or the San Buenarentura, more likely the former. He held short communication with the chief of the Indians.

The founding of the Mission of San Buenaventura T uld indicate that Iarge numbers of Indians were in the vicinity, and that the place had superior inducements for sustaining the establisbment and recruiting proselytes.

The name Taqniruine seens to be the original of the present Hueneme, aud is locally referred to the diame of a celebrated chief.

Mugu (Point Mugu) is quite likely the original name of one of their villages, although it may be from the Spanish muga, which really desiguates the character of the point.

We may here premise that bence to Point Concepcion Ferrelo gives the distauce at thirty leagnes, whereas it is only between twenty and twenty-one leagnes, and we may reasonably be guided in the adoption of this scale through the Santa Barbara Cbannel, because be bad pleasant weather and light variable winds throughout.

But pending that examination along the main shore I refer to the other two islands not seen by Cabrillo and Ferrelo.

La Isla de Santa Batlora, Vizciǹn's chart.

Santa Barbara Is]ancl.

He has not mentioned it ind vidualy in his narrative. It is laid down as a small island in a relatively correct position. His name is retained. This island is in latitude $33^{\circ} 30^{\prime}$, and rises 547 feet above the sea; it can be seeu a distance of twenty-seven miles.

La Isla de San Nicolas, Vizenino.

San Nicolas Island.

The southeast poiut is in latiture $33^{\circ} 16^{\prime}$. It is not
FERRELO.

and they passed on thence the following day, Tuestlay, and proceeded abont eight leagnes on a coast northwest and southeast, and they saw on the land a village of Indians near the sea, and the honses large, in the manner of those of New Spain; and they anchored in frout of a very large valley on the coast. Here came to the shipe many very good canoes, which held in each one twelve or thirteen Indiaus, and they gave them information of Christians who were journeying in the interior. The coast is from northwest to southeast. Here they gave them some presents, with which they were very mnch pleased,

They made signs that in seven days they could go where the Spaniards were travelling, and Juan Rodriguez was determined to send two Spaniards to the interior. They also made signs that there was a great river. With these Indians they sent a letter at a venture to tho Christians. They gave the name to this village of el Pueblo de las Canoas. They go covered with some skins of animals; they are fishermen, and eat the fish raw; they also eat agaves. This village is in thirty-five and one-third degrees. The country witbin is a very beantiful valley, and they made sigus that there was in that valley much maize and much food. There appear within this valley some monntaius very high, and the land is very rugged. They call Christians Taquimine. Here they took possession: here they remained mutil Fridas, the thirteenth of the said month. 


\section{CABRILLO.}

ULLOA AND VIZCAINO.

Tuesday, on the tenth of Oetoher, they discorered some villages of peaceable Indiaus, with whom they traded, which they named los Pueblos de las Canoas, because they had a great many canoes, and they are in thirty and five degrees and a third; 


\section{DAVIDSON.}

mentioned in his uarrative, but is on lis chart, where it is placed close alongsido and to tho westward of Santa Barbara Island, and even smaller. Ho has oither committed tho error that Tebeukoff has done in lis atlas (18t8) of laying down Suuta Barbara as two isiets, or he saw ouly the highest point of San Nicolas Island, which is 890 fect aboro the sea and visible at a distance of thirtyfour miles. Supposing that he sailed from the north harbor of Santa Catalina Islaud to the throat of the Santa Barbira Chanuel (reckoned as lying between Anacapa lslaud and Point Hneneme), he passed not nearer than fifteen miles to Santa Barbara Islaud and forty-two miles to San Nicolas Island. Tho former is visible in clear wonther with a sharp lookout; the latter is not visible nnless by extrnordinary refraction.

As Vizcaino gives a graphic description of his passage throngh the Santa Barbara Channel, we interrupt Ferrelo's narrative to condense it.

The Islauds of the Santa Barbara Channel.

To the broad passage hetween tho rnainland from Point Hueneme to Point Concepcion and the islands from Anacapa to San Mignel, Vizcaino (p. 95) gives the name El Canal de Santa Barbara. Ho is the first to call attention to the parallelism of these islands with the continental shore.

This channel is sixty-five miles loug nearly east and west, and rauges from eleven to twenty-six miles in breadtl. His statement that there aro six islands in this channel must inclucle the islands which he named San Nicolas and Santa Barbara, and which are laid down by him half way between Santa Catalina Island and Anacapa. His chart gives a very fair representation of the archipelago and its relation to the mainland. This archipelago is now known as tho Sauta Barbara Islands, aud embraces all of them from San Mignel to San Nicolas and San Clemento.

Cabrillo's vessels left Buenaventura and reached the "Pincon," Iatitude $34^{\circ} 22$ ', four leagnes west of San Buenarentura. This coast is bordered hy high and steop mountains, the water is alkali, and it was doubtless but sparsely inhabiter.
Fridas, the thirteentin of the said month of Octolser, they departed from the Pueblo de las Canoas on their royage, aud proceeded this day six or seren leagues, and passed two large islands which exteud four leagues each one, ind are four leagnes from the contineut. They are muinhabiter, becanse there is no water on them; and they have good ports. 
(Pp. 94,95.) Beyoud Santa Catalina there is a regular rotr of islands from four to six leagnes distant from each otber. Some are large aud other's small, but all are populous, and the inhabitants trade with each other and with those of the coutinent. These islands take up from the first one to the last one, nearly a distance of one hundred leagnes; and they follow each in the same direetion as the nainland; and tneir number, largeuess, and proximity often oceasion the Philipine ships in thein return to NeTr Spain, to mistake them for the Continent; and thus to keep at a distance from them. They are, however, very populous, and have a safe passage hetwixt them and the mainland, in some parts trvelre, in others ten, and the narromest eight. leagnes broad, ealled ol Canal de Santa Darbara, and which lies East aud West. The ships being arrived venr the continent, at the month of this Canal, a boat came off with four paddles, bringing an Indian, who was the King of the Conston the mainland. * * * Withim an hour after the Indian nas gone, a southeast wind sprang up, and was the only gale from that quarter they had felt during their voyage. And it being directly fair, the General thought proper to defer his visit to the Indian King till his return. * * * Accordingly they set all their sails, and as the gale lasted from seven in the erening of the $3 \mathrm{rd}$ of December till eight a'elock the day following (p. 98), tho ships had vearly renched the last cluster of islands in the Canal, which are six in number, and distant two leagnes from each other. The Caual is about trenty-fonr lengues in length, and the const of the coutinent verg pleasantly interspersed with woods, and has a great number of Indian Villages. Iu the vight following the day of Santa Barbara the wind shifted to the northwest, which eansed great consternation, it heing dark, and the ships among islands and in the chamel where the sea ran very high. This gale lasted all night and the following two dass; on the third it abated; hut thes had lost sight of their consort among the islands on the day of San Nicolas. With fair weather the ships sailed out of this arehipelago. * * * 
DATIDSON.

La Islia de gente Barbada, Vizeaìno's chart.

Anacapa Islaud, Jatitnde $34^{\circ} 01^{\prime}$.

This island is distinetly visible from San Buenaventura, and is distant serenteen wiles, althongh not nearly so large as mentioued by Ferrelo. It is four and a balf miles jong but very narrow, and presents its broad side to the northern shore west of San Bnenaveutnra. In approaching it from the east; from under Point Dume, it is seen projected on the Island of Santa Crnz, and cannot be distingtished from it if the atmosphere is rery clear. In this case the whole mass of the two islands, and even a part of Santa Rosa to the south, will show as one very large island, and when seen from San Bnenaventura it might he supposed that only the end was visible towards the observer, and thus a strauger would be misled in his estimate of the size, \&c.

The island is mercly a great ridge of coarse saudstone rock reaching $9 \varepsilon 0$ fect elevation, barien, desolate, without water and without a harbor. When Vizeaìno was approaching it he must have supposed it was a great island, and he even lays it down on his chart with its greater leugth to the sonthwest.

The second island seen by Cabrillo is La Isla de San Aul,rosio of Vizcaino's chart, with a rocky islet laid down off its eastern point. This is the Island of Santa Cruz, of whieh the easterm point is in latitndo $34^{\circ} 02^{\prime}$.

Ferrelo has evidently confused the characteristics of the two islauds, because be visited neither, saw them under changiug aspects, aud got his inforwation from the Indians by signs.

The name Aucapa is a corruption of Vaneonver's Iudian vame of the island. In his text he names it Enneeapah, but the engraver has spelled it Enecapal on the chart, and subsequent compiler's have evdeavored to give it a Spavish form. The Indian deep guttural pronnneiation is Eu-ni-aL-paght.

'Ihe vessels left the Rincon where the low lands of tho Carpiuteria hogin and stretch mestwardly for ten miles to Santa Barbara Point. He anchored off the Carpinteria, latitnde $34^{\circ}: 4^{\prime}$, about a wile west of Sand Point. Ferrelo's deseription is satisfactory.

Fom the Carpinteria the vessels continued past Sauta Barbara (at six and a half miles frow his starting poist) with its protecting hill, La Vigia, and the roeky elifis of the wesa for five wiles to the restward of the auchorage; past the low shore and treeless mesa cut by the lagoons behind Point Goleta; and anchored about four or five miles west of the latter place, probably inside the great ficlel of kelp skirting the coast; latiturle $34^{\circ} 25^{\prime}$.
FERRELO.

The eoast of the mainland runs west-northwest; the country is level, with many cabins and trees; and the fol. lowing Saturday they continued on their course, and procecded two leagies, no more, and they anchored opposite a valler very beatiful and rery popnlons, the lamil being level with many trees. Here canc canoes with fish to barter; they remained great frieuds.

Aud the Sunday following, the fifteenth day of the said unonth, they held on their voyage aloug the coast abont ten leagnes, and there were always many eanoes, for all this coast is very populous, and mauy Indians wele contiuually eoming aboard the ships, and they pointed ont to us the rillages and named thom by their names, which are Xnen, Bis, Sopouo, Alloe, Xabaagua, Xotococ, Potoltuc, Naebne, Quelqueme, Misinagua, $\left.{ }^{6}\right)$ Misesopano, Elquis, Coloc, Mugu, Xagua, Anacbuc, Partocae, Susuques, Quanmu, Gua, Asimn, Aguin, Casalie, Tucumn, Inepupu. All these villages extend from the first, Puchlo de las Canoas, which is called Xucu, as far as this place; they are in a very good country, with very good plains and many trees and calius; they go clothed with skins; they said that inland there were many towns, and much maizo at three days' distauce; they eall the maizo Oep; and also that there were many cows. They call the cows Cae; they also gave ns norice of some people n'ith beards, aud 
UNITED STATES COAST AND GEODETIO SURVEY.

CABRILILO.

ULLOA ANI) VJZC'AINO. 


\section{DAVIDSON.}

La Isla te San Lucas, Ferrelo.

Las Islas de San Lucas, Ferrelo. (See p1. 205, 226, 208.)

They snpposed that Santa Cruz Island and Santa Rosa Island wcre one, hecause ihcy saw them overlapped. 'They afterwads discovered them to be two islands, referring in Jannary, 15:33, to Santa Cruz Island as "the other islands of San Lucas," which the Indians called Limn or Limun, and to which the discoverers gave the name of San Salvador, forgcttiug that Santa Catalina had alrcady receired that name from thenı. It is the present Santa Cruz Island. 'The highest peak is Mt. Diablo (Devil's Peak), which is 2,410 feet above the sea, and is visible at a distance of fifty-frve milcs. The six villages which Ferrelo here names haro not a single correspondent in the nanes of the thirteen villages which he srbsequently learned to be on the three western islands.

On the 16th of October they sailed from the anchorage (lour or fire miles west of Goleta Point or eleven miles west of Sauta Barluara Light-house) to an anchorage trenty or trenty-one miles west of tho same light-house, and very likely abreast the opening of the Cañada del Refugio, in latitude $34^{\circ} 27^{\prime}$. On the 17 th they got as far as abreast the Gaviota Pass, latitude $34^{\circ} 28^{\prime}$, where Ferrelo mentions getting large quantities of fresh sardines. If anchored just iuside tho belp-field they would he in a fairly good position.

During these tro dass and the next Ferrelo does not mention seeing the Santa Barbara Istands; they may have been obscmred by fog, for in a few days they discover San Mignel and Santa Rosa IsIands. Gaviota anchorage is trelve miles east of Point Concepcion.

Vizeàno sailed through the Santa Barhara Channel wilhout stopping, but on the main shore, two-thirds of the distance from San Bnenarentura to Point Concepcion, he has made a clraming on his chart to represent "a large Indian town, adding "all this coast is wooded and free. from shoals."

El Calso de la Galera, 36 $\frac{10}{2}$, Cabrillo.

El Cabo de Galera, $36^{\circ}$ " aud more," Ferrelo.

La Punta de la Concepcion.

Point Concepcion, or Conception, in latitnde $34^{\circ} \mathbf{2 7 ^ { \prime }}$; correction to Ferrelo,- $1^{\circ} 33^{\prime}$ "aud more;" to Cabrillo, - $2003^{\prime}$.

Cabrillo's description of the cape is good. It cannot be mistaken for Point Arguello, eleren miles to the northwestward. For a detalled description of this cape, and of Point Arguello, sce Davidson's Cloast Pilot.

Vers curiously Vizcaino does not mention this remarkable headlaud, although he has it on his chart, but not vamed.

La Isla de San Lucas, Ferrelo. (See P1.206, 226, 228.) Las Islas de San Lucas, Férrejo.

They hat already seen the Island of Santa Rosa, as part of the Island of Santa Cruz when they overlapped and were named San Lucas. Now they discover San Miguel separated from the Island of Santa Rosa, which was supposed to be the western part of San Lucas.

Sauta. Crnz is twenty miles loug, Santa Rosa fiftcen miles, aurl the two, with the inter reuiug passages, thirtyscven miles, or trelre leagues, which Calorillo reclioned

\section{FERRELO.}

clothed. They passed this day parallel with the shore of a large island which is fifteen leagues in leugth, and they said that it was very popmlons, and that it coutained the following villages: Niquipos, Maxul, Xngua, Nitel, Macamo, Nimitopal. 'They named the islaur San Licas; it: is from this place to Pueblos de las Canoas eighteen leagues; the island is from the continent six leagnes.

Monday, the sixteenth of the said wonth, sailing along the coast they proceeded four leagues, and anchored in the erening opposite two villages; and also this daJ canoes wore continually coming to the ships, and they made signs that further on there were canoes mnch larger.

The Tuesclay following, the seventeenth day of the said month, they proceeded three leagnes with fair weather, aud there were with the ship from daybreak many canoes, and the Captain continually gave them many presents; and all this coast where they have passed is very populons; they brought with them a large qnantity of fiesh sardines very good; they say that inland there are manI villages and nuch food; these people dicl not eat any maize; they went clothed with skins, and wear their hair very long and tied np with cords very long and placed within the hair, and these strings have attached many small daggers of flint and wood and bone. The land is very excellent in appearance.

Wednesday, the eighteenth of the said month, they went runuing along the coast until ten o'clock, and saw all the coast populons, and lecause a fresh loreeze sprung np the canoes did not come.

'They came to a point which forms a cape like a galles, and they named it Cabo de Galera, and it is in a little over thisty and six degrees,

and because there was a fresh morthrest wind they steod of from the shore and discovered two islands, the one large, which bas eight Ieagnes of coast rumning east and rest; tho other has fonr leagnes, and in this small one there is a good port, and they aro peopled; they alre ten leagnes from the continent; they are called las Islas de San Lneas. From the mainland towards Cabo de Galera the shore trends rrest by nortl, and from Pneblo de las Cauoas to Cabo do Galera there is a very populons province, and they call it Xexu; it has mans languages 
CABRIỸT̃O.

ULLOS AND VIZCANOO.

and having sailed little in several days, on aceount of the too fine weather, the Wernesday, of the eighteentll of the said inonth, they arrived at a loug point, which forms a cape, aud on account of its length like a galles, they named it el Cabo de la Galera; this is in thirty and six degrees aud a half,

and because the wind was northwest fresh they nere carricd to leeward by the sea and they discovered two islauds, the one of eight leagues of coast East Trest, and the other of fonr; in this they discovered a port small, very good; they foumd them very populous; and these people, and all those of the coast passed loj, lived by fishing, and make beads from the lowes of fishes, to trade with tho other people of tho mainlaud, and thes are ter. leagues from the Cabo de Galera: rumning mest quarter to the northwest. Duriug the eight days they remained 


\section{DAVIDSON.}

eight leagues. San 1 lignel is seren and a half miles long, or two and a half leagues, whereas Cabrillo reekons it four leagues. Santa Rosa is the 1sla cle Cleto of Vizcaino.

Frow San Buenarentura to Poiut Concepeion the trend of the coast-line is a very little north of west, and the distance is actually twe ty leagnes. I suppose they propose to gire only the general direction of the coast.

La Isla rio la Posesion, Cabrillo.

La lsia de Posesion, Ferrelo.

Una de las Islas de San Lucas, Ferrelo.

La Isla de Baxos, Vizeaìno's chart.

Ciquinu ymu, Indian, Ferrelo.

San Mignel Island; the latitude of the anchorage is $34^{\circ} 03^{\prime}$ (see p. 226). Ferrelo namer the islaud La Isla re Jnan Rodriguez after Cabrillo's death.

El Puerto de la Posesion, Cabrillo, Ferrelo.

Cuyler's Harbor. (Sce pr. 204, 226, 236.)

This is the largest and best harbor around tho Island of San Miguel. It is a moderately large bay on the northeast face. Its extent is a little more than one mile be. tween the eastern and the western heads, and abont twothircls of a mile deep. It has bold shores and approaehes, and a large roeky islet half a mile north of the eastern head. This islet is five hondred yards in extent and 303 feet high, with a precipitous face to the north-northwest. Across the mouth of the harbor stretches a dense field of kelp having six fathoms of water throughont the greater part of it, but marked by two reefs and rocks near the middle, and almost in line betreen the heads. There are other rocky patches in the eastern part of the harhor.

Vessels coming into the harbor front the northwest pass within haif a mile of the western lieat, through the kelp, at a distance of only three hundred yards from the eliffs, and then hanl towarts the restern bight of the bay, where they anchor in five fathoms of water; over hard hottom, but protected from all save the north and east winds, which rarty blow. Tbe heavy swell from the strong northwest winds reaches well into the auchorage. (See p. 236.)

Vessels eannot easily enter by the eastern passage unless familiar with the dange:s and currents.

Water is found at one place on the steep sonthern hill face, and dnring winter water drains down the gully at the western part of the long beach sontheast from the anchorage.

The summit of the island lies only a mile sonthward of the anchorage, and is about seren hundret feet above the sea. It is in latitude $34^{\circ} 02^{\prime}$. There is not much vegetation upon the island, and the sonth and western part is swept by sand driving from the ocean beach.

The evidenees are rery strong of there having been it rery large Indian popnlation on this island, and foubt. less the fisbing mas good among the kelp-fields and rocky parches off the rest and northrest parts of the island.

They mas have leen in the broad bight between Point Concepeiou and Point Argnello.

\section{FERRELO.}

different from each other; they have many great wars with each other; it is from El Pneblo de las Canoas to El Cabo de Galera thirty leagues; they were in these islands mutil the following Wednesday, hecanse it mas very storuy.

Wednesday, the trenty-filth of the said month, they departed from the said islands, from the one which ras more to the windward; it has a vers good port, so that from all the storms of the sea no damage will be suffered hy those within its shelter; they ealled it La Posesion.

This day they advaneed little, as the wind was not tavarable; and in the middle of the following night they had a wind, south-southwest and west-southwest, with rain, so that they saw themselves in difficnlty, for it was an on-shore wind and they were near the land, and they conld not double the cape on one tack or the ofher; and the following Thurglay at vespers tho mind recred to the sonth, and thes proceeded on their courso ten longues to a 
CABRILLO.

they were well treated by the Imdians, every one going waked, and they have their faces painted in the manner of a chess board; to this port they gare the name de la Posesion 7

Weinesday, on the twenty-fifth, they sailed with fure weather from this Puerto de la Posesion, with wind sonthmest, and the following day they had it sonth, and southmest, with raiu showers, and fog, and thes hasl a rongh time, the wind blowing on shore, bcing near tho coast and a hears swell running. 


\section{DAVIDSON.}

The coast worth of Point Arguello to San Luis Obispo Baj bas a general trend north and south (true) for a distance of thirty-six miles.

Point Sal is eleven leagues from Point Concepcion, following the grand trend of the coast, and they were probably between Puint Purisima aud Point Sal.

Point Purisina is in latitude $34^{\circ} \cdot 1 t^{\prime}$.

Point Sal is in latitude $34^{\circ} 54^{\prime}$.

The Purisima River is in latitude $34^{\circ} 42^{\prime}$, just north of the bold Point Argnello. (See p. 210.)

This river was certainly the Purisima, emptriug jnst north of Point Arguello and known on the State min as the Santa Ynez. It comes through large valleys north of the Santa Yruez range, aud from seaward the country has the appearance of needing a large river for drainage. Vanconver in sailing past it recorded that it seemed to give the indications of a greater river than any since he barl left the Columbia.

The town of Xexo, Ferrelo.

This was at the opening of the ralley lying upon the Coro anchorage. There is water in the valley at all seasons, and some oak trees, but wood was not plenty iu 1850 when we were encamped here for more than three months.

El Puerto de Todos Suntos, Ferrelo.

El Coso anchorage in latitude $34^{\circ} 28^{\prime}$.

There can be no doubt about this port and anchorage being the same; and althongh Kobl says this avchorage wns east of Cape Concepcion, jet he confonnds it with San Luis Obispo, which is thirty-sis miles to the worthward.

El Pueblo de las Sardinas, Cabillo.

Los Pueblos de las Sardinas, Ferrelo.

El Pnerto de las Sardinas, 35̄응, Ferielo. (See pp. 210, 928.)

Cicacut, the Indian name, Ferrelo.

The Gaviota Anchorage off the Gaviota Pass; latitude $34^{\circ} 2 \tau^{\prime}$; correction to Ferrelo,-1 $1^{\circ} 13^{\prime}$. It was at this anchorage where they got so many fresh sardines on the 1ith of the month. It should be noted that it was their inst anchorage before reaching Point Conccpcion.

This gives us serenteen villages, includiug that at the C'oxo, in a distance of cleven miles, exactly one village to each strcanlet from the Gaviota Pass to the Coso.

Xncu : clsewhere Ferrelo says this prevince of Xucu r stencls from San Duevarentura to Point Concepeion.

\section{FERRELO.}

coast ruming north-northwest and south-southeast; all this coast is inbabited and in appearance good land; this night they kept out to sea, for they had an on-shore wind, and the Friday and Saturday following they were beating abont on one tack or the other with foul winds, and could gain nothing, and they were in thirty and six degrees aud a lalf, teu leagues from Cabo de Galera; and in the same nanner they held on during Monday and Tuesday to the thirty-first of the said mouth, the eve of All Saints' Day, beating about on one tack and the other; and they wished to approach the mainland in search of a great river of which they had notice, which was on the other side of the Cabode Galera, and becanse there were on land many indications of rivers, and jet they found no river. Nor did they auchor here for the coast was very hold. They fonnd duriug this month on this coast the weather as in Spain, from thirty-four degrees and upwards, and with wucb cold mornings and erenings and with storms, dark and clondy weather, and the air heavy.

Wednesday, at midnight, on the first clay of Norember, standing off, a stroug wind from the north-northwest struck them, which did not let them carry a palm of sail, and by the dawn of day freshened so much that they could do no less than seek shelter, and they took reíuge under Cabo fle Galera and anchored there and. went on shore, and because there was a large town which they called Xeso, and rood did not appear to be much at hand, they decided to go to Pueblo de las Sardinas, becanse there water and wood were very near and acees-

sible. They calleci this shelter under Galera Puerto de Todos Santos.

The following Thursday they went to Pueblos de las Sardinas, where they were taking in water and wook three days, and the natives of the conntry aided them and bronght wood and $w$ ater to the ships. This village of the Puerto de las Sardinas is called Cicacut, and the others, which are from this place to Cabo de Galera, are Cincut, Anacot, (7) Maquinanoa, Paltatre, Anacoat, Olesino, Coasat, $\left({ }^{8}\right)$ Paltocac, Tocaue, Opia, Opistopia,

Nocos, Yutum, Quiman, Micona, Garomisepona. An old Indian woman is princess of these villages, who came to the ships and slept two nights in the Captain's ship, aud the same did mauy Iuclians. The village of Ciucut appeared to lye the capital of the other villages, as they came there from other villages at the call of the princess; the village which is at the cape is called Xexo. From this port to Pueblo de las Canoas there is another province which they eall Xucu $\left({ }^{9}\right)$; they have their houses round, and covered rery well down to the ground; they go cov- 
CABRILAO.

Friday, Saturdas, and Sunday on the twenty-ninth, they kept under way, with the wind from all quarters, with mueh difficulty.

Monday and Tuesday, of the thirty-first, they had showors and cloudy weather.
ULLOA AND VIZCAINO.

Wednesday, the first of November, at midnight, heading towards the shore they had much wind northwest, whioh did not allow them to carry a palm of sail, and they returned around the Cabo de la Galera, which affords good protection from this wind.

Awl Tharsday, on the second of the same month, they were at the Pueblo do Sardinas, having sailed aloug forty leagnes of land very well populated, and with good people; and from one village, near this port, there came the principal people aboard the ship, and they danced to the sound of a drum, and a flute of the Castilians, and they slept on board, and during these festivities they took in water, and wood, and their houses were large, with donhe sloping roofs, liko those of New Spain, and their burying grounds were surrounded with boards: they give tho namo Sejo to this provinco: they ate acorns, hazel uats, and fish: they said that farther on there were people with elothes on.

H. Ex. $40-27$ 


\section{DAYTDSON.}

Cabrillo sass this proviueo is named Sejo. The name Coxo, or Cojo, is evideutly derived from these rords. (See the Coxo auchorage.)

"Tamales," a well-knowu Spanish article of food, prepared by boiling some kind of flesh, rolled in thin sheets of dongh, aud wrapped in the huslis of the naize. It is sold in San Frauciseo under the caue name.

Ll Puerto de las Surdiuas, $35^{\circ}{ }^{\circ}$, Ferrelo.

'The Gaviota Anchorage is in latitude $34^{\circ} .27^{\prime}$ : chroetion to Ferrelo, $-1^{\circ} 13^{\prime}$. (See p. 208.)

Kohl says this harbor is to the castward of Cape Coneepeion, and yet he adds, in clear contradictiou, that it "is perhaps tho plaee now known as San Simeon," whieh is to the northwart of Point Concepcion.

Compare with Tizcaino's description of the religious (?) ceremonies at the Great Depression of Santa Catalina Island (1n. 90-94) of the Notieia, ete.

Ll Rio de Ninestra Señora, Cabrillo. (See 1.208.) The l'urisima River, in latitude $34^{\circ} 42^{\prime}$. (See Davidsen's Coast Pilot for description and for the variety of uames it has had.)

At the first at tempt Ferrelo said ten leagues, and he was then letreen Point Purisima and Point Sal.

Twenty leagues Jjeyond this position, at six leagues from the coast which they wonld appear to be gradually a roiding, as the sontheaster was coming up.

Esteres Bay: The latitude of the haystack shajed El Norro, which is in the middle of this bay, is $35^{\circ} 22^{\prime}$; its eleration is 573 feet, and it forms is notoble landuark abreast the eutrance to Morro Bay.

There is no barbor for shelter on this part of the coast from the southerly gales of winter; but there is protection from the summer winds under the uorthern shores of Esteros Bay, San Luis Obispo Bay, and San Simeou Bar. Vizoamo appears to have been closer in shore and to havo recogniced these hights.

Las Sierras de Ban Martin, $: 3 \frac{10}{20}$, Cabrillo, 3710 , Ferrelo. La Sierra de Sinta Lueia, Vizeaivo.

Cape San Martin, latitnde $35^{\circ} 54^{\prime}$; eorrection to Calrillo and Ferrelo, $-10^{\circ} 36^{\prime}$. (See pp. 21:2, 224, 226.)

They were nearly abreast Lias Piedras Blaneas and Sun Simeon Bay, behind which rise the massive peaks of Rock.y Butte, in latitnde $35^{\circ} 41^{\prime}, 3,400$ teet ahove the seal and visible at sixty-five miles; and Pine Monntaiu, in latiturle $35^{\circ} 42^{\prime}, 3,500$ feet above the sea and visible at sixty-six miles; they are only threo miles apart. These furn the sonthern part of the bold, eompaet, aud nibroken hine of high monntains henco to Point Pines. It is the lighest and the boldest range of coast mountaius along this Pacific seaboard, reaching 6,200 feet elevation at Santa Lucia Mountain aud 5,100 feet at Coue Monntain or the Twin Peaks. Tho former is_only ten milcs from the coast-line and the latter only four or firo miles.

From his reseription he was distant about twenty fivo miles, nearly gouth, of the present Cape San Martin, w hicl,

\section{FERRELO.}

ered with the skins of many kinds of animals; they eat oals aeorns, and a graiu whieh is as large as maize, and

is white, of which they make tamales; it is good food. They say that inland there is mueh maize, and that men like us are travelling there: this port is in thirty and five degrees and two-thirds.

Monday, the sixth of the said month of November, they leparted from the said prort of Sardinas, and that day they mate hardly any progress, and until the following Friday they held on with little wind. This day they reached Cabo de Galera; throngh all this conrse they could not make use of the Indians who eame to board them with water and fish auil showed mneh good dispesitiou; they have in their villages their large public commous, and they have an inclosure like a cirele, aud arousd the inclosme they have many blocks of stone fastened in the gronnd, which project about three palms, and in the midulle of the inclosures they hare stieks of timber driven iuto the ground like masts, and very thiek; aud they have many pictures on these same posts, and we helievo that they worship then, for when they dance the g go dancing aronut the inelosure.

The Saturday following, the day of San Martin, ou tho elevent h of the said mouth of November, they proceeded, sailing along the land and they found theinselves this morning twelve leagues from the cape, in the samo place where they arrived first; and all this day they had a good wind so that they sailed along a eoast, rnuning nortluwest and sontheast full trenty leagnes; all this coast which they passer this day is a hold enast withont any shelter whatever,

and there oxtends a cordillera of sierra along the wholo of it, very lofty, fuld it is as high by the sea as on the land within; the sea beats upon it; they saw no populittiun nor smokes, and all the const, which has no shelter on the uolth, is uninluabited ; they named the monntain las Sierras de San Martin; they are in thirt? and seven degrees and a half; 
CABRILLO.

\section{Chapter IV.}

Which continucs line discoveries of the two vessets of Don Antonio de ivendogn in the South Sea.

Saturday, on the cleventh, they were coasting, with a southeast wiud and eontiunally they were looking for el Rio de Nuestra Señora, and rlicl not find it,

but a great rauge of uourtains rery high, with many trees, to $\pi$ hich the g gave the name Las Sierras de San Martin, and they are in thirty and seven degrees and a half,
ITLLOA AND VIZCAINO.

"This fair weather enabled the ships to get aw ay from the islands; and standing in for the contineut to take a draught of the coast, they found it extremely high and monntaillous,

but with some well sheltered bask, from one of which came fonr rusly eanoes."

[On his chart he ]ays down the large bight forming Esteros Bay with the notable Morro in the middle of its length, and the entranee to Morro Bay, but he gives no name.] "Here they had a formidable gale which lasted. until the 14th of Decemher;

and the weather clearing $u p$ a little in the daytime, the ships fonnd thomselres near a rory high and white ridge of mountains; but reddish towards the base, and covered with woods. This rauge theg call the Sierra de Santa Lucia; it is the nsual landfall for the China ships (p. 100)." 


\section{DAVIDSON.}

is the great dauking spur or buttress for this monutain ranure. He was sixty miles souti by east from tho termination of tho rauge at Carmel Bay, and the nountains aro so bigh and so near the coast-lino that he could have seen them if tho weather permitted; but it is almost certain that he estimated his latitude and did not observe it. Eren Mount Carmel, nortl of the Sur, is 4,417 feet aboro the sea aud visible at a distanco of seventy-fivo miles. It is in latitude $35^{\circ} 22^{\prime}$ and is ouly eight miles insido of Point Sur. The latitude of tho Twin Peaks ovorlooking Cape Martin is $36^{\circ} 03^{\prime}$. Tho highest peak is 5,100 feet above the sen and is visible at a distanco of eighty miles, and on] 5 fonr or fivo miles inshore.

Wo applied tho name to Capo San Martin somo years since to commemorate this landfall of Cabrillo.

Point Sur, or The Sur: This is a remarkablo rocky looking head, rising 358 feet above the sea, and is connected with the mainlaud by a narrow low neck of sand dunes. See Dariusou's Coast Pilot.

On lis chart Vizcaino has, in this position, a slightly projeeting point and the legend "Point appearing as an island."

Vancouver thonght it was an island. It is in latitude $39^{\circ} \mathbf{1 8 ^ { \prime }}$.

El-Rin dol Curmelo, Vizeà̀mo.

Carmel Bay and River, in latitnde $36^{\circ} 34^{\prime}$.

The bay of Carmel is twelvo milos northwestward of tho island-like point known as "The Snr." The river is a stream of minor importance, and in 1770 a mission was fonnder ou its banls aud overboking the bay.

El Cabo de Martin, $38^{\circ}$, Cabrillo, Ferrelo.

El Cabo de San Mrartin, 3710, Ferrelo.

La Punta do Pinos, Vizeaino (p. lo1).

La Punta do los Pinos, reecnt charts.

Point Pinos, iu latitndo $36^{\circ} 38^{\prime}$. (Sec pr. 210, 2:24, 936, 236.)

I thiuk their Cabo de Martin, when thoy were driven off the coast sear las Piedras Blancas, was the termination of the momntain rango at or near Carmel Bay, in latitude $36^{\circ} 30^{\prime}$. They conld not hare seen the pine-clad hill behind Point Pinos at the distance of sixty miles. But on the return of the expedition they explieitly state that the Cabo de Sau Martin which they made was in thirty-seven and a balf degrees.

If tre assumo this later deterunination of his position to bo the better one, tlie correction to Ferrelo's latitude is, $-1000^{\prime}$.

On his rosago northward Cabrillo was forced by tho southeast storm to leave the eoast before he sighted Point Pinos, and afterwards ho mado the land near Fort Ross, in latitudo $38^{\circ} 35^{\prime}$.

Vizcamo's description cammol bo mistaken. Except that ho gives no idea of tho lleight of the pine-covered bill lying between Carmel Bay and Monterey Bay, it rlescribes the point and applies to no other.

VI Prerto de Monte-Rey, Vizeaino.

Mlonterey Harbor, in latitude $36^{\circ} 31^{\prime}$.

This harbor is well protected from the southeast at orma which wero thoso most destructivo to the early navigators, and therefore Vizeaino oxtolled it far beyond its real merits and thus mislerl Constanzo and others in 1769.
FERRELO

the spurs of these and of the sierras on the northwest form a eape which projects into the sea in thirty and eight degrees; they named it Cabo de Martin. 


\section{CABRILLO.}

and at the termination of them, at the north west, it forms a cape which is in thirty and eight degrees, and they named it Cape Martin.
ULLOA AND YIZCAINNO.
(P. 100.) "Four leagues farther a river enters into the sea between some rocks, after a precipitato course from some high and white mountains; the banks of this stream are covered with black and white poplars, willows, and other trees and branbles known in Spain. This river is called del Carmelo.

"Two leagnes farther nortliward of the river Carmelo there is a famous port, and between this and the river there is a forest of pine trees two leagues in extent, aud there is a point of Jand at the entrauce to the harbor that is called Punta de Piuos (p. 100).
(P. 101.) "On the 16th of December the squadrou put in to this port which was ealled de Monte-Rey (in honor of Don Autonio de Mendoza, the Count of Monte-Rey, Viceroy of New Spain; by whom they lad been sent on this Discuvery, in the name of his Majesty).

$(P .307$.$) "This is a very good harlyor, ant affords good$ 
DAVIDSON.

Althongh open to the northwest winds they do not blow home with great force.

Yizeaino applied the uame only to the southeast angle of the bay where the town of Monterey is situated. This is evilent from his outline chart, although he has the general features to the north and northrestward. For a detailed description of the harbor and bay see Darillsan’s Const Pilot.

Point Año Nuevo, latitude $37^{\circ} 06^{\prime}$.

Vizcaino has no reference to this low point or to the uassire spmr behind it in his naratire; and no name ou his chart, although there is a point faintly indieater in this locality. (Sce p. 224; Black Mlonntain.)

Half Moen Bay, latitude $37^{\circ} 30^{\prime}$.

The inclication of this bay is very clear on the chart of Vizcuino, lunt there is no name given to it, and no reference wade to it in the narrative. The general trend of the coast is good. North of Half Moon Bay, Vizeaino's chart says," the coast is wooded," which is one of its cbaracteristics for a rery short distance.

La Baia de Pinos, Cabrille.

La Bahia de los Piuos, Ferrelo; latitude $39^{\circ}$ and a "little more."

La Ensenaia de los Farallones, later Span ish authority

The Gulf of the Firallones of the U. S. Coast and Geodetic Survey. (Seo p. 2:22.)

Correetion to Ferrelo, -1 - $00^{\prime}$ and a "little more."

This gulf, extending from Point San Pedro, in latitucle $35^{\circ} 35^{\prime}$, to Poiut Reyes, in latitude $38^{\circ} 00^{\prime}$, and enturacing the Faralloues de los Frayles, was seen by Cabrilio and Ferrelo, as is shown by 1 heir narratives, on their first return from the northwari, ridas, the 16th of Novenleer, 1542.

Whether they intended the name to inchde this great bight is doubtful, although Cabrillo culled it a "great gnif," but this may mean only the bight between Point. Rejes and Ballenas Point. There are no pines south of those which are on the ridges neal Ilount Tamalpais* nutil we reach Point Sin Pedro and then they are sparse until the crest-7ine is reached about latitude $37 \circ 25$.

Portins Nove Albionis, Drake, $38^{\circ}$ and $38^{\circ} 30^{\prime}$.

El Puerto de San Francisco. Vizeaino.

Sir Francis Drake's Bay.

Drake's Bay, latitude $38000^{\prime}$.

Drake's Bay is a capital harbor in northwest wiuds, such as Drake encounteres. It is easily entered, sheltered by high lands, and a ressel may anchor in three fathoms che moder the shore iu good holding ground. Drake s vessel drew thilteen teet of water "to make lyer swim," atd it would appear that when she was leaking he moved her to the beach and eareener her.

It he had buen insile the Estero Limantour, of which be conld not have detected the entrance from his res. sel, be: would necessarily have been vory elose to either shore. Aud lad be seen it ho woild not have dared to enter it without somnding it ont. It has ouly thirteen foot of water on the lar at the highest tirles, and be would not have hazarded his vessel in entering snelt at leubtful anchorage. Nor wonlel le have risked the posTamal pais, the contry if the Tamal Indians. The Table Monnt.
ain of Bechey. 
DRAKE.

\section{ULLOA AND VICZAIYO.}

protection, and is sheltered from all winds. It has extensivo forests, and au infinite number of very great pines, straight and smooth, fit for masts and yards; likewise evergreen oaks of a prodigious size proper for bnilding ships. Here also are rose-trees, white thorns, firs, willows, aud poplars; large clear lakes, fine pastures, and arable lands. * * * The sea abonuds with oysters, lobsters, erahs, ete. Also buge sea rolves and whales. This harbor is surronuded with rancherias of indiaus, a well-looking attable people; * * * who oxpressed great concern when the Captain and tender sailed out of this harbor on the third of Januars, $150 \%$, * * * in seareh of the Cabo Mlendocino.
"Hero" (1. 116).

"They were foreibly earried sonthward from forty-eight to thirty-eight degrees, whère they found the land low and plain, with some few hills eovered with Snow. J nne 17 tb, $[1579],(p .117)$ they came to a conrevient barbour and contiuned there till Jily 23 rl, during which, though in the beight of Suwmer, set they hal constant nipping Cold (neither for fourteen days could they see the Sun for the fogginess of the Air), *** the Trees being without Leaves, and the Grond withont Grass, even in June and July : * * $*$ Tho' the real Cause of this Extremity is uncertain, yet it is judged to proceet from the large Continent of America and $A$ sia, near together. northward of this place, from whose high Mountains, always covered with Snow, the North-West Winds, which nsually blow on those Coasts, bring this almost unsufferable sharpuess, which the Sun in his greatest Heat is not able to dissolve, from wheuce the Earth is so barted, and the Snow lies at their Doors almost in the midst of Summer, bnt is never off their Hills, from whence proceeded those stinking Fogs throngh which the Stin eannot pierce, nor draw the Vapors ligher into the Air, ex-
"The Capitana aud Fragata had wo sooner left the barbor of Monterey to seek for the Cabo de Mendociuo, than they had a formidable wind which lasted to the sisth of January, the day of the Los [Santos] Reyes, and earried them beyond the Puerto de San Erancisco. And the day after that of Los lieyes, which was the 7 th of Jammary, the wind suddeuly shifted to the north west and blew son, ew hat fiererly, but they mere able to make some headway; and the Fragata conchuding there was no necessity to seek a barhor from this. wind continned ber voyage; and the Capitana thinking they were in company dich not show a light; so in the morning they were not in sight of each other, aud the General returned with the Capitana to the Fuerto de San Francisco to wait for the Fragata; but they did not hear of her until they retnrned to dlexico. Another reason which prompted the Capitana to put into Puerto de San Francisco, was to malse a recoumaissance of $\mathrm{it}$, aud learn if anylhing was to be found of the ship San Angustin, which came upon the coast in 1595, * * * uuder the P'ilot Sebastian Rotrignez Cermeñon; and heing in this port she was 
sibility of attack from the Indians in sucb a contracted place. He donbtless auchored in Drake's Bay, and the reef $i$ his plan represents in a crude manncr the reef off the easterumost point of Point Rejes Head. In a rongh slretch of his anchorage it is called Portus Nova Albionis.

Tho "World Encompassed" describes Drake lcaving the coast in latitude $43^{\circ}$ and going son thward, as follows: "Aud ho drew backe againe without landing, til we came within thirtie-eight degrees towards the line. In which height, it pleased God to send us into a faire and good bay, with a good wind to enter the same."

In the "Hero" tho narrator says:

"From the height of 48 clegrees, iu which now we were, to 38 , wo fond the lind, by coasting alongst it, to bee but low and reasonable plaine; every hill (whereof we saw mang, but nove verie high), though it were in June, and the Sumo in his wearest approach onto them, being covered with snow.

"In 39 degrees 30 minutes, we fell in with a convenient and fit harborongh, aud Jnne 17 th came to an anchor therein." * * *

Contiuning in lle: "World Eoconipassed," the narrator writes:

"In this bay wo ankered the serentienth of Jnne, and the peo pof the Countery, having their bonses close by the water's side, shewed thenselves unto us, and sent a present to our Gencrall. * * * Our Generall called this coutery Nova Albion, and that for two canses: the one, in respect of the white bankes aud cliffes, which ls towardes the sea; and tho other, becanse it might have some affinitio with our countrey in name, which sometime was so called.

"Thero is no part of earch hero to bee talien "lp, wherein theire is not some speeiall likelihood of gold or silver.

"At our departure hence on1" Generall set up a monument to our being thero." * * *

From a recent visit to Drake's Bay (1886), we feel assured he was abchored close under the point. From this place he could not see any fair indication of there heing a lagoon like-the Estero de Limantour. Moreover, that he was not in that estero would appear by the following precautions be took agaiust any surpriso by the natives:

"The third day following, viz, the 21st, our ship having received a leake at sea, was bronght to anchor necrer the shore, that, her goods being landed, she might be repaired; but for that wo were to prenent auy danger that might chance against our safety, our Generall first of all landed his men, witb all necessary promission, to hnild tents and mike a fort for the defence of our selves and goods; and that wee might rnder the shelter of it with moro safety (what ever should befal) end onr bnsiness" (p. 122). "When they [the Iodiaus] came to the top" of lill, at the hottom whereof wee had built our fort.they made a stand." * * *

On tho sketch of Portus Nove Albiouis there is the legend, "Frda corporum laceraetione ct erebris in montibus sacrifiesis hujeis Novi Albiouis portus incle Drecis jumbis coronote decesinu deflent."

(By lorrible lacerations of their hodies and by frequent sacrifices in the monntains, the inlobitants of this 


\section{DRAKE.}

cept the fierce Winds do sometimes seatter them; aud when gone, the Fogs return as before."

Chap. VI., p. 118.

"Next day after their comiug to Auchor in the harbour afore-mentioned, the Natives of the Country diseorering them, sent a Man to them iu a Canoe, with all Expedition. * * * June 23, their Ship heing Jeaky, came nearer the shore to Land thein Goods; but to pre. vent any surprize, tho Geveral sent his Men ashore first wilh all necessarjes for making Teuts, and a Fort for sccuriug their Purehase; * * * their Honses are dug round within the Earth, and have from the sarface to the Ground, Poles of Wood set up aud joined together at the Top liko a Spirecl Steeple, which being covered with Earth, no water can enter (p. 120), aud are very warm, the Door being also the Chimney to let ont the Smoke, which are mado Slopons, like the Scuttle of a Ship * * * (p. 121). The Geueral having experienced the treachery of other Infidels, provided against any Aiteration of their mind, setting up Tents, and intrenching themselves with Stone Walls; whiel done they grew more Secure. * * $\Rightarrow$ The Indians * * * coming to the Top of the Hill, at the Eottom whereof the liad built their Fort, they made a stand, where their chief speaker wearied himse]t, and them with a long oration. \& c. (I. 123), their Hiols ог king appeared.

(P. 128). "Having thished their Aftuirs the General and some of his Company made a Journey up into the Country, to observe their manner of Living, with the Nature and Commodities of the Conntry ; " * * the Injand was far different from the Seashore, it being a very frnitful soi],furuished with all Necessaries, and stored with large fat Deer, whereof they saw 'Thousands in an Herd, \&c. * * *

"This Country Geueral Drake called Nova Albion, both becanse it had white Cliffs towards the Sea, and that its Name might have some likeness to Englaud, which was formerly so called. Before they went hence, the Geueral caused a Moument to be erected, signifying the English had been there, and asserted the Rights of Queen Elizabeth and her Successors to that Kingdom, all engraven in a Plate of Brass, and Nail'd to a great firm Post, with the Time of their Arrival, the Queen's Name, and the free Resiguation of the Country by the King and People into her Hands; likewise her Picture and Arans, and nnderneath the General's Arms. * * *

"July the 23rd, they [the Indians] took a sorlowful leave of them, but loth to part with them, they went to the top of the Hills to keep sight of theu as loug as possible, making Fires before, behind, aud at each side of them, therein they supposed Sacrifices were ofiered to their happy Vogage."

\section{ULLOA AND VIZCAINO.}

wrecked and driven on shore by a contrary wiud; and among those who were there at that occurrence was the chief pilot, 


\section{DAYIDSOY}

port of New Albion deplore the departure of Drake now twice crowned.)

Amoug the Nicasio Indians of the Nicasio Valloy, Tyiug to the eastward of Drake's Bay, there is said to be a tradition that Drake anchored in this bay; that some of bis crew deserterl and lived among the Indians; and that he gave the uatives some seeds, and amoug other things some hard ship-biscnit, which they innocently planterl. Ho also left among thom a sow aud a boar; and the early Spaniards report that when they came to this regiou the conntry wis filled with wild hogs.

Bullenas Bay: To the sonthward of Drake's Bay, and nearly half way to San Francisco Bay eutrance, thero is a small cove somewlat protected by a reef from the northwest swell. The name Volanos or Bolanos, Trizcaino's pilot, at once suggests the origin of the present name i. c., the Bay of Bolanos.

La Punta de los Reyes, Tizcaino.

Point Reyes, latiturle $38^{\circ} 00^{\prime}$.

The ehart of Vizcaino gives a fair idea of Point Reyes and its relation to Drake's Bay, but the latter is exaggeraterl. He has an entrance to a large estero now known as the Estero de Limantour, or Drake's Lagoon.

For a detailed deseription of this remarkable hearland, which forms the northern bouzdary of the Gulf of the Firallones, see Davidson's Coast Pilot.

The Isles of St. James, Drake.

Los Frayles, Vizcaino's chart.

Los Farallones de Ios Erayles of the later Spanish navigators.

The North Farallones, the Mliddle Farallon, and Sontly. east Farallon, latitude $37^{\circ} 42^{\prime}$.

It is a curions faet that neither Calurillo nor Ferrelo mention these notable islets, althongh they describe and name the great gulf under Point Reyes Head. Drake's deseriptiou arlmits of no donbt whaterer. Vizcaino does not mention this extensive gromp of high islets in his narrative, but has five "Frayles" laid dowu off his port of San Francisco, doubless the North Farallones, and a large islet close iushore and to the sonthward. This latter is certainly the largest and highest, or the Southeast Farallon, aud it wonld appear that he olid not sail between it and the shore, beeanse ho has lair it down dangerously near to the coast.

This remarkable group of islands forms a notabje featnre in the vavigation of this part of the coast. Tle Sontheast Farallon is a high rocky islet abont one mile in extent, rising almuptly from deep water, with several well-defined heads, one of which attains an elevation (s] 360 foet This jolet may sometimes have been mistakeu for several islets close together. It lies in latitnie $33^{\circ}$ $42^{\prime}$, tronty-fonr miles broad off the Golden Gate, and eighteen miles true south of Point Reyes Hoarl. It is a wild granitic mass of rock, without a particle of soil, and the resort and breering-place of thonsauds of sea-lions and millions of sea birds. There are two er three landing jlaces around the island. 
DRAKE.

\section{RAT}

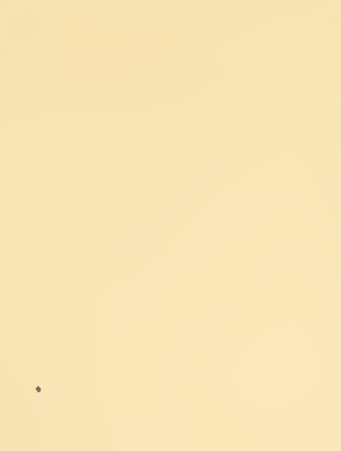

\author{
VLIATA AND VIZCAINO.
}

Franciseo de Volaños, who was with the present expedition. He reeoguized the plaee and afirmed that they bad left on shore a groat quantity of wax, aud ebests of silks, and the General was anxions to diseover some vestiges of these.

"The Capitana eane to ancbor bebind a point of laud which makes this port [Puerto de San Francisco, i. e. Drake's Bay ], and which he ealled La Punta de los Reyes; but no one was sent ashore that they might be in readiness for the teuder; and on the day following, the Capitana sailed ont in seareb for her. The wind was northwest and light aud the Capitana moved slowly.
"A little witbont their Harbour Jye certain Isles, and by them the Islands of St. James, wherein are plenty of Seals and Fowls, and Landing ou one of them the next day, they amplied themselves with compotent Provision for some time (Hero, p. 129).

"The 23 of July they took a sorrasfuil farewell of vs but being loath to leave rs, they presently runt to the top of the hils to keepe vs in sight as long as they eonld, Inaking fires.

"Not farre without this barborongh did lye eertain Islands (we call them the Islands of Saint Jemes), having on them plentifull and great store of Seales and birds, with one of which ree fell JuTy 24 , whereon we found such provisiou as might competently sorue our turue for a while. We departed againe the day nert tollowing, viz, July 25." (World Eneompassed, 1. 134.) 


\section{DAVIDSON.}

The North Farallones is a group of four smaller islets and low rocks gathered togetber in a somewhat compact body. The four principal islets are high, barren, and almost inacessible. Tho highest rises to an elevation of 158 feet. The group lies six and three-fifths miles northwest by west from the Sontheast Farallon, and twelve miles sonth-sonth west from the resteru extremity of Point Rejes Head.

The depth of water aronnd these islauds is thirty fathoms, and the same contiunes well in towards the shore so that it is somerlat strange that Cabrillo, Ferrelo, and Vizcaino did not go inside of them; they could not have been coasting yery closely along the main shore.

Freqnently these islets are hidden by tho fogs even when the shores are fairly free and risible.

Rio Grande de San Sebastian, Vizeaino's eluart.

Tomales Bay:

The month of Tonales Bay is in latitude $38^{\circ} 14^{\prime}$.

This body of water is shown on Vizcaino's chart but no mention is mado of $i t$ in the narrative. It is indicated in the locality of Bodega Bay, six leagues north of Point Reyes, by a large river leading many leagues to the eastward. It might be considered the Estero Americano, but this stream is quite varrow, not straight, and is not easily made ont from seaward. It is almost certainly Tomales Bay, which wonld show the mile-wicle entranee between the ridge of Tomales Peninsula and tho equally high land forming the eastern slore of the bay.

Tomales Bay is ten miles long with a navigablo channel a good distance in. But the bar at tho cntrance is generally marked by breakers, and has less than ten feet of water npon it at low tide.

On old Spanish charts we fiud the mame sumetines spelled Tamales; and it would seem a reasonable conclusion that it was named after the Tamal Indians.

The vossels of Cabrillo were compelled by stress ot weather to leavo the coast when near Cape San Martin. From his description I place him about twenty-five miles nearly sonth of the present Capo San Martia, which is the great flanking spnr tron the mountains of the Santa Lacia range. Ho was sixty miles sonth by east from the termination of the range at Carmel Bay, and the monnt. ains аге se high that lie may possibly have seen them; but it is more probable that ho estimated his distauce, and also that the range was cloud-eapped.

In the heavy "southeaster" it is evident that their small vessels were very serionsly in danger, and that for safety each had to look ont for itself.

$\Delta$ rough plottiog of their conrses elearly indicates that they were far a way from the coast.

"Echaron nn Romero" means that they east lots to decide who should go on the pilgrimage to the church and make tho offering to Our Lady Guadalupe. A marginal note in IIercera states: "Voto de los Mlarineros do la Nao de D. Antonio de Mendoģa, à Nuestra Seũora del Rosero."

They sight land to the north ward of the Slavianski or. Rassian River on the lith ; the summit of Ross Mountain is over 2,200 feet above tho sea and only three niles from the shoro. It is in latitude $38^{\circ} 30^{\prime}$, and is visible from the latitude of Point Reyes.
FERRELO

This sane night of Saturday, a fonr o'clock in the night, being in the sea about six leagnes from tho coast, lying to waiting for the day, with a southeast wind, so great a storm struck them from the southwest and the sonthsouthwest with rain aud dark clondy weather, that they could not lieep up a handbreadth of sail, and it made them scui with a small foresail, with much labor, all the night, and the Sunday following the tempost broke upon thesn with mnch greater violence, which continued that day and night until the following Monday at noon, and the storm was as great as can lie experienced in Spain. Ou Saturday night they lost sight of their consort.

Monday, the thirteenth of the said month of November, at the hom of Vespers, tho weather cleared up and the wind veered to the west, and immediately they made sail and went in seareh of their consort steering towards the land, praying to God that they might diseover her, as they much feared that she would be Iost; they mere running to the north and to the north-northwest; with the wind west and west-northwest; and the following Tuesday at daybreak they had sight of the land, and they were ablo to hold on until the evening, and they conld see that the land was very high, and they croised along the coast to see if there was any port where they might take shelter; and so great was tho swoll of the sea that it was fearfnl to bclold; and the coast was bold, and the 
CABRILLO.

and at four hours in the night, commeneing to blow strongly the wind from the south-sontheast, and from the southwest, with slowers, and hears clouds, and a great wea that uearly engulfed them, and at dawn, it blowing tremendously, it was not possiblo to run, except $\pi$ ith the least amount of sail, before the wind, and on account of the strong sea, wind, and dense clouds, one ressel lost sight of the other, and that one vessel threw overboard ererything that conld lighten her, from the deck, beeause the storm was very great; and on the Capitana, seeiug themselves in the greatest danger, they vowed a pilgrim-

age [echarou un Romero] to onr Laly of the Rosary aud the blessed Mother of Pity, for her merey, and she farored them with a little fair-meather. And Mondas, on the thirteenth of said montl, they were heading towards the lind, in seareh of the other vessel, and during the night they hept a lookont, in order not to lose sight of anything, aud to search for sone slielter, and to make the lund. 


\section{DAYIDSOX.}

Cabo de Pinos, Cabrillo, $40^{\circ}$ "and more."

Northwest Cape, Russian. (See pp. 224, 228, 236.)

This is the hold high spur of the caast monntains nearly overbanging Fort Ross Cove, in latitude $38^{\circ} 31^{\prime}$. This gives a correction to Calrillo aud Ferrelo of, $-1^{\circ} 29^{\prime}$.

The vessels were not near ellough to the coast to sue the details of the shore-line.

This bold shonleter with the forests upon it was the distiuguishing mark for the Russian ships when raking the small harbor of Fort Ross. The massive character of the orography is well cxlyibited in the latest editions of the Const Surrey charts.

Cabrillo's description is goon, even to the direction of the coast-line.

The Russian na.ne "Northwest Cape" was not really applied to the cape above clescribed, but to the comparatively low roeky point at the northwest part of the lort Ross Cove. (Ses Davillsou's Coast Pilot.)

Punta de Arena.

Point Arena, latitude $35^{\circ} 55^{\prime}$.

This point lies thirty-sereu miles northwest, along a straight coast-line, from the Northwest Cape at Fort Ross Core; and Cabrillo conid not have seen the point itself whea he was in his latitude of Ciabo de Pinos. But he conde lare readily made out the ligh mountains lying seven or eight uiles southenst of Point Arena and bordering the coast. Moreover, if he sailed along the shore beyonil Cabo de Piuos before the gale struck him (as they apparently got observations of the sun at noon), he may have actnally seen Point Arena. As he had seen no point with such marked preculiarities it is strange he did not describe it. The long terrace land stretches ont three miles from the base of the mountaius and terminates in vertical clifts from two hundred and sixty feet to forty and fifty feet in leight, with whitish faces in the sonlight.

Cabrillu's liriay is an error, as shown by the context; it shonlt be Tlutursiay.

liana de l'inos, Cabriilo.

Lá Bahit de los Pinos, Ferrelo, 3:10 and " more."

Binsenada de los Frayles.

The Gulf of tho Farallones.

Wrake's Bay, latitude $38^{\circ} 00^{\prime}$; correction to Forrelo, -10 $10^{\prime}$ and "1nore" (See p. 214.)

i'he "Great Gulf" of Cabrillo may possibly be intented to embrace the lsight from loint Reyes lfead to l'oint Boneta, or even to Point Sau Pedro. it could not have been intended for Loriega Bay, becanse this has no characteristies of at great gnlf, and there bavo been no pines upon Borlegat Hearl, l'oint 'Tomales, or the eastern shore of the bay since its occupation io the last fifty years; nor is there auy iuclication of such a growth previously. On the ofther hand, al part of the rirlges and all the galches from Mount 'Tumalpais aro even yet forest clau. This is quito a murked feature from seaward. Mneover, the reported latitule carrics the lociation to the Gulf of the: Farallones.
FERRELO.

mountains rery lotts, and at ereuing they lay to for 'pst; it is a const rumiug northwest to southeast; they perceived the land at a point which projects into the Ocean, which forms a cape, and the point is covered with trees, and it is in forty degrees.

Weduesdas, the fifteeuth day of the said mouth, they had sight of their consort, for which they gave many thanks to God, as they had considered her last; sud they came vp with her and joined her at evening. They of the other ship enduret more dauger and risk than thoso of the Captain's ressel, on aceount ol its beiug swall and having no leck. This laul" where they were sailing is to appentance verg good, but they stw no Iudians nor smolies. Tlleve aro grabd Sierras coveral with suow; there ar mang treos. At wight they loweres? the sails and lay to.

On the following Thursday, the sixteenth of the said month of November, at disblycak, they were upon a largo grulf which was formed by a cliange of direction of the shore, which appearer to havea port and a river, and they weut beatiug abont this dayand the night and the Friday folloming, nutil they saw that there was no rivor yor any shelter; and to take possession they cast anchor in fortyfive fathoms. They disl not dare to laud on account of the higl sea. 'This gult is in thirty aud nino degrees and i.ore, and it is all corerod with pines to the sea. They grave it the naue of La Bahia de las Piuos. The followi ug night thry hay to wntil the next day. 
There is a Cape, projecting into the sea, very much wooded, with rery high pine trees, and they called it Cabo de Pinos, and obserring the Sun, they found themselves in forty degrees, and more, to the northwest,

from whence they reeognized more than fifteen leagues of coast, all the land high, aud the coast muning from northwest southeast :

And Fritiay, the sixteenth, thes arrived at $\approx$ Great Gulf, that lookerl hke a harbor, and they called it Pinos. 
DAVIDSON.

El Cabo de San Martin. (See pp. 210, 222, 223, 235.)

This is cither the nortbern limit of tho Sierra Santa Lucla near Point Carmcl or the Sau Martin which they made in the early part of the rerage when they were storm struck and had to ruu before it. Tho former would probably be the more !ikely, because on the 18th they wore running from near Point Reyes all clay along tho coast, and passing the decp bight of Monterey Bay ronld mako the pine-covered monutain behind Point. Pinos or the higher mountains beyoud Point Carmel by nightfall.

It is cvideut that Forrolo runs ahead in his narrativo to describe in general terms tho appearaueo of the coast rango of mountains from the Gnlf of the Farallones to Cape San Martin, aud then returns to tako up the cletails. IIis Sicras Nevadas fórn the monntain range of the Peniusula of San l'rancisco, in whose erest-lino is Loma Prieta reaching an elevation of nearly 3,000 feet, and which is about thirteen miles iusido of Point Aũo Nuero lying under his Snowy Cape. Mount Bache, in the same range, is iu latitude $370062^{\prime}$ aud reaches 3,825 feet elevation. His description is good, although it would apply with greater forec to the stupendons barrier of the seaward face of the Sicra Santa Lucia; ho may very probably havo lad both mountain ranges in his miud at the tiue of cumpiliug Lis narrative.

Las Sierras Nevalas, Ferrelo.

La Sicrra do Santa Cruz.

The Peninsula of San Trancisco.

Cabo de Nieve, Ferrelo, $38 z^{\circ}$.

Cabo de Nieve, Cabrillo, $38^{\circ}$.

Black Honntain, latitude $37^{\circ} 09^{\prime}$.

This is the massire wostern spur or buttress of the San Francisco Peninsula Mountains immediately behind aud alnost overhauging the low Poiut Año Nuovo. The ships were not close chough to the coast for Cabrillo to noto the details of the shore-lino, bnt ho took in the broad, bold features, and graphiea!l 5 describes them uuder tho aspect of a heary winter. I placo this great shoulder of the rauge in latitude $33^{\circ} 09^{\prime}$, whence the correction to Ferrelo and Cabrillo is, $-11^{\circ} 31^{\prime}$.

Mount Baclee, reaching 3,825 ticet elevation, is in latitude $: i^{\circ} 0 \mathrm{en}_{2}^{\prime \prime}$.

Ferrclo again runs ahead of evouts in liss narrative in mentioning his approach to the Santa Barbara Islauds aud then returns and describes the coast from Calo do Pinos (Northmest Cape at Fort Ross). (Sce plp. 210, 292, $226,236$.

By plotting his course as far as practicable during the storm and his again making the coast, $\mathrm{I}$ fix his approach theroto south of Point Arena, at the cape ho describes, but even then ho mnst have been twenty-five miles from the coast-]ine.

He could not harofollowed tho shore very closely or ho wonld Lave seon the bays of Lsteros, San Lnis Obispo, and Point Sal. Moreover the coast was thickly popnlated from tho San Carpofero to Point Concepeion; and trom Carmel Bay northward the coast was also thickly inhal,ited.

\section{FERRELO.}

The following Saturday they were runpiug along the coast, and they found themsel res at night off $\mathrm{El} \mathrm{Cabo} \mathrm{de}$ San Martiu.

All the coast they passed by this day is very oold, and there is a great s mell of the soa, and the lind is rery lotty; thero are monntains which rise to the sky and the sea beats upon then. Whilo sailiag ncar the land it appears as if they wonld fall upon the ships; thoy aro covered with suow to tho summit.

'They gavo thon the namo of lass Sierrus Nevadas, and the principal one forms a cape which projects into the sea, which they namol Cabo de Nicre. The coast runs north-northrest and south-sontheast. It does not appear that Indians inhabit this coast. This Cabo de Nieve is in thirty and eight degrees and two-thirds, and always when tho wind blew from the northwest it mado the weather fair and clear.

Thursday, on the twenty-third das of the month, they approached on a return course the islands of San Lucas, and ouo of them named la Posesion; and they ran along all the coast, point by point, from el Cabo de Pinos to them, and thes found no shelter, so that of necessity ther lad to return to the said island, on accont of having these ciars a very stroug west-northwest wind, and the swell of the Bea was very great. From Cabo de San Martin to Cabo do Pinos wo saw uo Indians, boeanse of the coast being bold and without shclter and rugged; and on the sontheast side of Cabo do irartin for lifteen leagues they found tho country inhabited, and many smokes, tor tho land is good; but from ol Cabo do Kartin as far as to forty degrees wo saw no signs of Indians. 


\section{CABRILLO.}

ULLOA AND VIZCAINOO.

And on the eighteenth thes were seeking for a port,

and discovered some snow covered sierras, with a cape, which projected therefrom, which they called Cako do Niere, in thirty and eight degrees and two-thirds, and tho whole land and coast, pessesses this peculiarity, that, whenever the wind blows from the northwest, the reather is all clear, withont any send or ansthing else; and from the thirty and seven degrees and a half, hence to the forty degrees, this coast runs northwest southeast; 


\section{DAVIDSON.}

El Cabo de San Martin, Ferrelo, 37 $\frac{1}{2}^{\circ}$. (See pp. 210, 222, 224, 236.)

The present Cape San Martin is iu latitude $35^{\circ} 54^{\prime}$, but Jount Carmel, one of the high peaks of the Sierra Santa Lneia (Ferrelo's Sierra San Martin) would probably be the first mountain he would see when approaching from the north across the Gulf of Nonterey. In the clear sky of northwest weather he would have seen it when he was abreast of bis Cabo de Nieve, or Point Aũo Nuevo. It is in latitude $36^{\circ} 22^{\prime}$, rises to an elevation of 4,417 feet, and is visible at a distance of seventy-five miles. It is only eight miles inside of Point Sur.

La Isla de la Posesion, Cabrilla.

Una de las Islas de San Lucas, Cabrillo.

Isla de Posesion, Ferrelo.

La Isla de Juan Rodrignez, Ferrelo.

Ciquimnymn, Indian, Ferrelo.

La Isla de Baxos, Vizeaìno.

San Miguel Island. (See pp. 204, 206, 236.)

This is the resternmost of the Santa Barbara Islands. (For a detailed description see Davidson's Coast Pilot of California, \&e.)

El Puerto de la Posesion, Cabrillo.

This is Cuyler's Harbor in latitude $34^{\circ} 03^{\prime}$, already described. (See p. 236.)
The "other islands of San Lueas" is San Salvador, Ferrclo. (See p. 204.)

Limun or Limu, Iudian, Fercelo.

Santa Cruz Island, already deseribed. (For a minute deseription of the island see Daridson's Coast Pilot of California, \&c. )

He apparently forgets that Cabrillo named Santa Catalina Islaud San Salvador, and he slightly changes the spelling of the Indian uame.

\section{FERRELO.}

El Cabo de San Martin is in thirty aud seven degrees and a half.

While wintering in this $\mathrm{I}=1 \mathrm{a}$ de Posesion, on the third day of January, 1543, departed from this present life Juan Rodriguez Cabrillo, Captain of the said ships, from a fall which he had on the same islaud at the former time when they were there, by which he broke an arm vear the shoulder. He left for Captain the Chief Pilot, who was one Bartolome Ferrelo, a native of the Levant; and he ehargerl them nuch at the time of his death that they should not give up the discovery, as far as possible, of all that eoast. They named the island La Isla de Juan Rodriguez. The Indians eall this island Ciquimumm, and another they call Nicalque, and the other they call Limu. In this islani de la Posesion, there are two villages; the one is called Zaco (10) and the other Nimollollo. On one of the otber islauds there aro three villages; one they call Nichochi, aud auother Coycoy, and the other Estocoloco. On the other island the ro are eight villages, which are, Miquesesquelua, Poele, Pisqueno, Pualnacatup, Patiquin, Patiquilid, Ninumu, Mooe, Pilidquay, Lilibeque.

The Indians of these islands are very poor. Thes are fishermen; they eat nothing hut,fish; they sleep on tho ground; all their business and employment is to fish. In each house they say there are tifty souls. They live very swinisbly; they go naked. They were in these islands from the twenty-third of November to the nineteenth of Jannary. In all this time, which was almost two montlis, there were very hard wiutry storms on the laud aud the sea. The winds which prevailed most were west-sonthwest and south-southrest and west-northwest. The weather was very tempestuous.

Friclay, the nineteenth day of the month of January, 1543 , they set sail from the island of Juan Rodriguez, whieh is called Ciquimugmn by the vatives, to go to the mainland in search of some supplies of provisions fol. their voyage, and in leaviug the port a heavy storm from the wcst-northwest struek them, which made them put into the otber islands of San Lucas, and they anchored off the island of Limun, to which they gave the name of Sau Salvador, and they found it neessary to weigh anchor again, becanse it had no port more nuller the shelter of the islands, and the wind veered arouud from all points, and they sailed arouud these islands eight days with the wind very fonl, sheltering themselves under the islauds from the bad weather; and on the twenty-seventh of the said month they entered the same port of the island of Juan Rodrignez where they were before. The greatest hindrance they had was hecause the winds were not steads, but weut veering ahout from one point to another. Those which are the more constant are from the west-northwest and from the rrest-sonthwest. 
and because they did not find any port, they had to go to la Isla de la Posesion, which is one of the Islands of San Lucas, and they entered there Thursday, on the twentythird of Norember, and because it is a good port, they repaired the small ressel, and made her staunch, as she was going to sink.

In the aforesaid port they remained, until the end of December, on account of the bad weather, with great cold and suow, even to the sea level, rain from heaven, and heary clonds; and as the southeast storm was continuing, there was so great a surf, althongh in a land. locked harbor, that sometimes for three and four daye, it was not possible to go ou shore. Finally, Friday, on the nineteenth of January of the following year, one thousand five hundred and forty-three, with great labor they arrived at the Puerto de Sardinas, 


\section{DAVIDSON}

La Isla de San Sebastian, Ferrelo's consort. (See pp. 204, 236.)

La Isla de Sau Lucas, Ferrelo.

La Isla do Cleto, Vizcaino's chart.

Nicalque, Indian, Ferrelo.

Santa Rosa Island, lying between San Miguel Island and Santa Cruz Islaucl.

Ils probably lost his anchor in Becher's Bay on the northeast fice of the island, where he could have watered his vessel.

For minute description of the island see Davidsou's Coast Pilot.

El Puerto de las Sardiuas, Ferrelo.

Cicacut, Indian, Ferrelo.

The Gaviota anchorage. (Sce pp. 208, 210.)

Iu the Gaviota Pass there are evideuces of large Indian Raucherias, where the Iudians could retire from the coast. line in winter and thus avoid the full effects of the storms, and at the same time cngage in hunting or cnltirato the ground.

La Isla do San Salvador, Ferrelo.

Santa Cruz Island. (See pp. 204, 236, 238.)

If wo suppose that he ran nearly south, and haif way between Santa Cruz and San Nicolas, he would probably have seen the islands of San Miguel, Santa Rosa, Santa Cruz, Anacapa, Sauta Catalina (with Santa Barbara in line aud not distinguishahle), and San Nicolas. Heconld not have seen San Clemente Island; Anacapa is small; and Santa Catalina would, at that distance, appear small. San Nicolas would he seen moderately smail, hecause he would make it endwise.

IVben the unusual northeast wind changed and the west-northwest wiud eame up with the large sea always - accompanying it, it is very unlikely that he was eren two hnudred miles to the wind ward of the islands. And zet we find Kohl making the unaccountable blunder of sup. posing that the six islands which Ferrelo saw "were donbtless the Sandwich Islands"!

E1 Cabo de Pinos, Ferrelo.

Already described as the mountain mass behind Fort Russ Cove. (See p1. 210,222, 224, 236.)

This is the Punta de Arena in latitude $38^{\circ} 57^{\prime}$, but he does not name it; the land trends to the northwestward from Borlega to this point, then the shore changes its direetion to north-northwest.

Li Cabo de Fortumas, Cabrillo, $41^{\circ}$.

They anw the great monntain mass which reaches a beight of nearly 4,300 feet a little to the northward of

\section{FERRELO.}

Tnesday, the twenty-ninth of the said mocth of January, they departed from the island of Juan Rodrignez for the islaud of San Lucas, which is in the middle of tho others, to take up certain auchors which they had left in a storm, not being able to raise them; aud which they recovered, ind took in water.

They departed from this island of San Lncas Monday, the twelfth day of the month of February, which they could not do sooner on account of the bad weather, which gave them winds and much suow. It is inhabited, and the people are like those of the other island. The Indians call it Nicalque. There are three villages on it, which are called Nicochi, Coycoy, Coloco.

This day they went to Puerto de las Sardinas, to take in rood and other things neccssary for thcir voyage, as they were not to be obtained on those islands.

Vednesday, on the fourteenth of the said month, they departed from El Puerto de Sardinas, having taken a boat-load of wood, and thcy did not dare to remain longer there on account of the great swell of the ocean; they did not find so many Indiaus as hefore, nor any fishing on account of the winter; the natives eat oak acorns and other seeds and herlas of the field without cooking. From this place they proceeded to the island of Sau Salvador, because they were there more sccure from the storms, that they might he ahle to make sail and run ont to sea.

Sunday, the eighteen th das of the said month of February, they departed from the island of San Salvador with a moderate wind from northeast, and they ran along to the southwest, because they had heen told that there were other islands toward the sonthwest; they werc at dusk this day abont twelve leagues from the island of San Salvad or, and they saw six islands, some large and others small.

This day a sailor died, and the followiug Monday, at daybreak, they were at sea about ten leagues to the windward of the islands, and with the wind west-northwest they were standiug off five days to the southwest, and after they had proceeded about one huudred loagues they found the wind more violent and the sea high;

and Thursday, the twenty-second of the said month of February, they again stood in shore to endea vor to reach Caho de Piuos, with the wind south-southeast, which continued three days, and was increasing each day; and the Sunday following, at daybreak, they gaiucd sight of Cabo de Pinos, and they wero this day at dusk twenty leagues to windward on a coast runuing north west, and southeast, and it is bold and without shelter; there was no smoke seen on the land, and they saw a point which formed the extremity of the land, which changed the coast to tho northwest; in the middle of the night the wind suddenly shifted to the south-southwest, and they ran to the west-northwest until day, and in the norning the wind shifted to the west-southwest with great violence, which held on until the following Tresday; they ran to the northwest. 
UNITED STATES COAST AND GEODETIC SURVEY.

CABRILLO.

ULLOA AND VIZCAINO.

whence they left on the fourteenth of February.

And Monday, on the twenty-sixth of sala montn, tney were at a point which makes a cape, which they called Cabo de Fortunas, on account of the maus daugers which they had experienced in those days, and it is in forty and one degress: 


\section{DAVIDSON.}

Point Delgada at Shelter Cove; and continues as a bold range to tho north of Cape Mendocizo. They could not have seen Point Delgada because it is low and projected on the luase of the coast mountains. If he saw King Peak, or the monntain behind Cape Gorda, or Mount Pierce behind Cape Mendocino, then his latitnde must be assumed to have beon derived from dead reckoning. Cape Mendocino is in $40^{\circ} 27^{\prime}$, Cape Gorda in $40^{\circ} \mathrm{I2} 3^{\prime}$, but the high crest-line of the mountains runs to the south of $40^{\circ}$. This course from Point Arena is nearly worth-נ1ortlwest, true.

Vizcaino's two ships had been separated in a storm, aud the crews were in a terribly bad condition from scurvy.

These are the high mountains lying eastwardly from Point Delgada, and cnlminating in King Peak in latitude $40^{\circ} 09^{\prime}$, at au elevation of 4,265 feet.

Calo Mendocino, Vizeaìno's pilots, $41^{\circ}$, withont observation.

Cape Meudocino, latitude $40^{\circ}: 2 \%^{\prime}$.

The description and the position of the calye in relation to the foregoing monutains are good for Cape Mendocino, but I think the latitude ho gives is merely a report, for they do not appear to have observed the sun, and his chart places it in $4 I^{\circ} 40^{\prime}$. 'The higl monntaius, rising to an elevation of 3,400 feet behind the cape, might well be covered with snow if the winter was severo, as we may assume it was from the narrative.

'They conld not havo been in $4 L^{\circ} 30^{\prime}$, becanse after being driven morthward by the violent southeaster for six days (to January 20) they were then only in $42^{\circ}$. Vizeaino's chart lays down a prominent headland in latitude $407_{2}^{\circ}$ (obtained by bringing up the scale of degrees from Point Piuos to Point Reyes) and a marked headland in $41^{\circ}$. Between these two capes he has a deep receding of the shore-line to the east and vortheast, with a large river emptying into the northeast part of this great bight.

I am satisfied that this apparent eastern recession os the shore-line was the low conntry around Humboldt Bay and Eel and Mad Rivers. The large river which he has drawu was a snpposition of its existence on account ot the low lying valley in that direction giving passage way to the discolored waters of Mad River and Pigeou River

Cabo Mendociuo, Vizcaino's chart, $41^{\circ} 40^{\prime}$.

Point St. George, in latitude $41^{\circ} 46^{\prime}$.

Sonth of Cape Mendocino Vizcaino notes the coast line as rugged, but no name appears until "Cabo Mendocino" stands abreast a cape of white cliffis in latitude $41^{\circ} 40^{\prime}$, with mountaius to the soutluward covered with snow. The shore-line from Trinidad to this cape is laid down straight, but for twenty miles it is continued to the northeast. He conld not have been near the coast, on iccount of the heary weather, or lo wonld not have missed Reddiug Rock north of Trinidad, nor the notable elifts of Gold I3luff in $41^{\circ}$ 95'. And especially does he omit any sigu of tho rocky islets of the Dragon Rocks forming St. George's Recf in $41^{\circ} 50^{\prime}$. As there is a marked recession of the high land behind Point St. George on account of large lakes and several streams uaking in trom the distaut monntains, he may have

\section{FERRELO.}

Tuesday, the twenty-seventh of the said wonth, the wind veered to the south-southwest, which held on all day; they ran to the west-northwest with the foresails lowered, for it blew violently; at the approach of night the wind shifted to the west; they ran all night to the sonth with but little sail; there was a high sea which broke over them. 
"The ship progressed very slowly, but little by little, on Sunday the twelfth day of January [I603] the flagship came in siglt of some very high mountains of a reddish color, and fourteen leagues farther to tho north. west a chopped off cape came upon the sea, and near to it some snowy mountains; and the pilots judged that this should be the Cape Mendocino, which is [reported to be] in forty and one degrees ol latitude.

:The day following, which reckons itself the thirteenth of January, a southeast wind came up with the greatest fury, and with it a fine sleet that appeared like snow. This wind raised such a tremendons sea, that every moment it appeared as if the ship must founder: and all be Iost; and to avoid its fury, and not to reaeh a higher latitude, beeanse they feared the excessive cold and the increased violence of the storms in the higher latitudes, and it being the depth of winter, it was deemed the best to lay to until the wind was favorable ayd. then makse sail for Acapulco.

"With this decision came a little strength to mi:igate the sufferings of the people, for they now thonght thoy would be able to hold ont some days longer than if ther went farther north.

"And on the fourteently of the sard nionth tho wearher cleared a little that day and the sun shone ont, so that the pilots rere able to observe, and they found themselves near to this Cabo Mendocino, and the currents had carried them even this far in two days. Almost immediately the siry was obseured that day with a thick fog, and dark, and a cold drizzle which they had not expected; and as the wind was still at southeast the ship lay to the sea with the wind abeam? 


\section{DAVIDSON.}

FERRFLO.

supposert the shore recerled more to the northeast than it really does.

E1 Cabo Blanco de San Sebastian.

Vizcaino does not state positively that this cape is in . his observed latitude of $42^{\circ}$, which, by the way, is the only latitude he mentions iu his narrative. His chart lays lown a cape of white cliffs iu $41^{\circ} 40^{\prime}$, where he places Cape Mendocino. There are the white cliffs of the Gold Bluffs in $41^{\circ} 25^{\prime}$, and the notable white sand dunes just nerilh of Mack's Arch. These saud dunes are three miles in length and rise to 170 feet elevation aud are a marked feature in the shore line. They lie in latitude $42^{\circ} 14^{\prime}$ and the rerdure-clad mountaius behind them rise to 1,500 feet aud are pine covered on the upper slopes and crest line.

In Iatitnde $42^{\circ} 05^{\prime}$ the Coast Surrey has named a bold headland, seen from Pelican Bay, Cape Ferrelo, and in latitude $42^{\circ} 18^{\prime}$ a second notable head has been pamed Cape Sebastian, but without other iutention than commemorating these uames.

"A Barl bay," Drake $42^{\circ}$.

Chetko Bay, latitnde $42^{\circ} 0 \mathrm{~L}^{\prime}$.

This is an open roadstead exposed to the full force of the southerly swell. It is at the southern termination of fifty miles of high rugged coast coming from Port Orford to the Chetko River. In striking the coast Drake conld find no anchorage between Paint Orford and this place, and none other near this except Crescent City Harbor, seventeen miles southward, and which he would hardly approach when the dangerous Dragou Rocks or St. George's Reef guarded the shore. Chetko anchorage is but slightly protected oven from the northwest swell by the long ronnding head of Cape Ferrelo, fire or six miles to the west-northwest. The shore line to the westward is bound by rocks, and there are several sumken rocks with breaks upon them in the anchorage. Weknow from experience that it is not a comfortable auchorage; and it may very well be accepted as the anchoring place of Drake in latitude $42^{\circ}$.

Trinidad Head, latitude $41^{\circ} 03^{\prime}$.

Redding Rock, latitude $41^{\circ} 22^{\prime}$.

The tender was then off Trinidad Head in latitude 41 $03^{\prime}$, and supposing that they had observed the-latitude correctly, ho conld have found no protection anywhere in the vicinity of Cape Mendocino in $40^{\circ} 2 \bar{r}^{\prime}$, or of Trinidad Head.

In their demoralized condition they were anxious to get shelter, and the first object they could tind would he the ledding Rock in latitude $41^{\circ} 22^{\prime}$, only five miles off a nearly straight coast-liue. It is only eighty-three feet high aud of limited extent, but sufficient to gire a lee for such a small ressel; morcover it is evident that the storm was not rery severe. This protection was his only refuge, and his reforence to Cape Mendocino was merely to the nearest known landfall. 


\section{DRAKE. \\ DRAKE.}




\section{DAYIDSON}

Cabo Blauco, Vizcaino (Flores), $43^{\circ}$.

Cape Orford, or Cape Blauco, in latitude $42^{\circ} 51^{\prime}$.

North of this latitude the coast does not run to the northivest; on the contrary it trends nearly north (magnetic). Yet we may suppose that in running along the coast aud making the cape with the north west wind with its clangerous reet before him be fell back npon his instructions to return.

This cape has a waterthe afternoon sun, but there is no river near it which he would dare to enter. In May, 1886, the cliffs around Cape Orford were mostly covered with verdure, aud only swall spaces showed whitish.

Taking his narrative as accurately descriptive, we may assume that his Caho Bianco was the white sand dune line (just south of Cape Sebastian) in latitude $42^{\circ} 14^{\prime}$, and already described. Hence the coast runs to the west of north to Cape Orford. After passing these bright dunes and keeping the coast-line moderately closo aboard he wonld open the well marked valley of the Rogue River in latitude $42025^{\prime}$. This stream has a tolerably wide mouth and has heen entered by vessels; but the current is very strong and there is a short breaking bar off the entrance; while ontside of it there is a very dangerous reef which he would certainly avoid.

The Chetko River and Smith's Rirer are in the deep bight of Pelican Bay under $42^{\circ}$, and he would hardly have run in there from around the Dragon Rocks. The Chetko mouth is closed by a gravel harrier in dry seasons.

On the 28th of February, 1543, they were out of sight of land, and prohably iu latitude $411^{\circ}$, allowing a correction of one and a half degrees to bis reported latitude.

"Y no tener puente." In Spauish, puente does not mean exactly "deck" when applied to a ship; it means the place where the batteries of a ship are situated.

They were probaly in latitude $42^{\circ} 30^{\prime}$ abreast of Rogue River and working their way hack to El Cabo de Pinos; but they must have been seventy miles broad off the coast, which was therefore not visible. The logs were brought down the flooded rivers of this part of the coast; and they always have been a fenture off the coast north of Mendocino.
FERRELO.

The Tednesday following, the twenty-eighth day of the said month, at daybreak, the wind shifted directly to the southwest, and it did not blow hard. This day they observed the latitude in forty-three degrees. Towards night the wind freshened and shitted to the south-southwest. They ran this night to the west-northwest with much difficulty, and Thursday at daybreak the wind shifted to the southwest with great fury, and the seas came from many parts, which harassed them much, and broke over the ships, which, not haviug the decks [as in a man-of-Tar], if Grod should not suceor them, they could not eseape, and not being able to lay to, of necessity they scudded northeast towards the land; and now, holding themselves for lost, they commended themselves to our Lady of Guadalupe, and made their promises [or offerings], and ran thus until three o'clock in the afternoon with much fear and labor, for they saw they were going to be lost, and already they perceived many sigus of the laud which was near, as small hirds, and logs very fresl, which had fioated from some rivers, although from the dark and clondy weather the land did not appear. At this hour the Mother of God succored them with the grace of her Soll, and there came a very violent rainstorm from the north, which made them scud all that night and the following day uutil sunset to the south, with the foresails 
CABRILLO.

from the trenty-seventu of February, until Thursday, the first of March, they ran the greatest danger, and stull more on the night 0 ? the same das, and when it became daglight, they gave thanks to Our Iady, and to Her Blessed Son, for having saved them from so dark and terrible a night, because the storm is not felt somuch in the daytime: and when the weather cleared up, on the first of Hareb, they ouserved the sun, in forts and four degrees, with so much cold that they were freezing,

\section{ULLOA AND VIZCAİTO.}

and on the nineteenth of Jaunary, the pilot Autonio Flores, who was in the tender, found himself in latitnde forly and three degrees, where the land makes a cape, or point, which was named Cabo Blanco, and from which the coast hegins to run to the uorthrest, and very close to it, he found a River of large volume, and deep, that npon its bauks it had rery lirgo Ashes, Willows, Elaers, and other trees of Castile; and wisbing to enter it, the c!nrrents monld not perait him."

[And thereupon Ensign Alferez Martin Aguilar, commander of the tender, and the pilot Antonio Flores, fuding they were in a latitude heyond that mentioned in the Instructions of the Viceroy, that there was no appearance of the flag-ship, and that the crew were very sickly, agreed to return to Acapulco.] 
DAVIDSON.

On Saturday, March 3, 1543, they were approaching the coast south of Point Arena, lut Ferrelo goes back in his narrative when he was north of Cape Mendocino. The large fresh water streams breaking through the coast line north of that Cape, and up to $42^{\circ}$ are: Eel River in Iatitude $40^{\circ} 38^{\prime}$, IIumboldt Bay in latitude $40^{\circ} 46^{\prime}$, Mad River in $40^{\circ} 53^{\prime}$, Pigeon River in $41^{\circ}$, the Klamath River in $41^{\circ} 34^{\prime}$, Crescent City in $41^{\circ} 44^{\prime}$, Smith's Rirer in $41^{\mathrm{C}}$ $54^{\prime}$, the Winchuk in $41^{\circ} 58^{\prime}$, the Chetko River in $42^{\circ} 02^{\prime}$, Pistol River in $42^{\circ} 15^{\prime}$, and the Rogue River in $42024^{\prime}$. All of these bring down winter freshets of discolored water abounding in the uprooted trees from their banks.

EI Cabo de Pinos, in latitnde $38^{\circ} 30^{\prime}$.

The mountain mass overhanging Fort Ross, and already described (pp. 222, 224, 228). I should juclge the vessel to have been twenty fire miles off the land and even somewhat to the southward of the cape. From the higlest point attained, in latitude $421^{\circ}$, to this position abreast Calo de Pinos the vessel ran two hundred and seventy-five miles between the morning of March 1 and the evening of March 3, giving about fice miles per hour. If they continnerl on their east-southeast course they should have seen Poiut Reyes and the Farallones off the Golden Gate.

La Isla de Juan Rodriguez, Ferrelo.

San Miguel Island and Cuyler's Harbor. (See pp. 206, 2:26.)

It broke on the reef which is in the middle of the harbor, and he was unacquainted with the dangers of Wil6on's Reef off the approaches and with the best place to anchor under the western shore of the harbor. (See description nnder Isla de San Sebastian).

Puerto de la Isla de Sau Salvador, Ferrelo.

Sningglers' Core.

Santa Cruz Island. (See p. 204.)

Ferrelo's port is the Smugglers' Cove ou the short southeast sirle of Santa Cruz Island.

Isla de San Sebastian, Ferrelo's consort.

Santa Rosa Island. (See p. 206.)

This is the first time the Cabrillo narrative has mentioned the Island of San Sebastian. It specifies the southsontheast side of the islaud where he songht shelter. As the Fragata was off Cuyler's Harhor in the evening (about twelve hours after the Capitana had passed it) with a heavy blow from the noithwest, he very naturally was afraid to approach the old anchorage because be evidently passed through the breakers and dangers of Wilson's Recf, orer one nile in extent, that lic three miles off the

\section{FERRELO.}

furled; and hecause there was a high sea from the south, it broke over them each time at the bow, and swept orer them as if over a rock, and the wind shiftei to the northwest and the north-northwest with great fury, so that it made them rum until Saturday, the third of March to the southeast, and to the east-sontheast, with such a high sea that it made them ery out without reserve that if God and His blessed Mother did not miraculonsly save them they could not escape. Saturday at noon the rrind modcrated aud remained at the northwest, for which they gave many thanks to our Lord. They suffered also in provisions, as they had only biscuit, and that damaged.

It appeared to them that there was a very large river, of which they bad much indication, between forty aud one degrees and forty and three, for they saw many sigus of it.

This das, in the evening, they recognized the Cabo de Pinos, and on account of the bigh sea which prevailed they conld do no less than run along the coast on the re turu conrse in search of a shelter. They experienced much cold.

Monday, ou the fifth day of the said month of March, 1543 , at lawn, they found themselres off the island of Juau Rodriguez, and they did not dare to enter the port on account of the great storm which prevailed, which broke the sea at the entrance of the harbor in fifteen fathoms; the wind was north-liorthwest; tho entrauce

is narrow; they ran ander the protection of the Isla do San Salvador on the southeast side; 
CABRILLO.

ULLOA AND VIZCAINO.

and Saturlay, on the third, they again turued round to examine el Cabo do Pinos, bnt owing to the strong wind they were forced to go

to la Isla de la Posesion, where thee arrived on the fifth, and on account of the heary breakers at the mouth of the harbor

they sought protection nnder the Isla de San Sebastran, under the side presented to the sonth-southeast, 


\section{DAVIDSON.}

northrest point of the island of San Miguel; and probably continued through the San Miguel Passage - seeking a lee under the shores of Santa Rosa Island; and . found protection anil anchorage between South Point and East Point under the shore facing to the south-southeast. The summit of Santa Rosa Island is in latitude $33^{\circ} 57^{\prime}$, and rises to 1,500 feet eleration.

He must have remained here fourteen days whilo tho other vessel was three days in Smugglers' Cove under Santa Cruz, and then searched for her consort at the Puerto de las Canoas, again at Smugglers' Cove, at San Diego, Port Quentin, and finally at the Island of Cerros.

There are four open anchorages on the sonth sicle of Santa Cruz Island and Smugglers' Cove at the short sontheast side. To reach this anchorage he must have sailed along the north shore of San Miguel Island, Santa Rosa Island, and Santa Cruz Island, and rounded the easternmost point of the latter to fiud shelter, from the northrest wiurl, at Smuggiers' Cove.

He previonsly says he olsserved the sun in forty-fonr degrees, i. e., in $42 \frac{10}{3}$ latitude, after applying the probable correction.

San Bueuaventura (El Pueblo de las Canoas) is only ninetecn miles north-northeast from Sungglers' Cove. (See p. 204.)

Puerto de Sau Miguel.

San Diego Bay. (See pp. 192, 194.)

La Bahia de San Mateo.

Todos Santos Bay. (See p. 190.)

El Puerto de la Posesion.

Port San Quentin, Lower California. (See p. 184.)

La Isla de Cedros.

Cerros Island. (See p. 174.)

This ship, the Fragata, did not enter the port on Juan Rodrignez Island (Cnyler Flarbor on San Miguel), but sought shelter under the south-sontheast side of the Island of Sau Sebastian (Santa Rosa Island). (See p. 236 for
FERKELO.

aud the night before comiug with a violent tempest, with only tro suall foresails, the other ship disappeared, so that they suspected that the sea had swallowed it up, and they conld not discover it any more, even after dayhreak;

they believe they must have been in forty-four degrees when the last storm overtook them and compelled then to ruu to leeward.

Thursday, the eighth of the said month, they departed from the island of San Salvador, to stand in for the mainland in search of tho other ship, and they proceeded to Pueblo de las Canoas and did not obtain news of the other ship; and here they took four Iudjans.

The Friday following, on the ninth of the said month, they departed from Pneblo de las Canoas and proceeded to the island of San Salvador and found no sigus of their eonsort.

Sunday, the eleventh of the said month, they camo near the Puerto de San Miguel, veither did they find here their consort пот ans uews of her; here they waited six days; here they took two boys to carry to New Spain for interpreters, aud left certain signals in ease the otrer ship should approaeh.

Satnrday, the seventeenth of the said month, they dcparted from the said Puerto de San Miguel; the following Sunday they arrived of the Batria de San Mateo and found no signs of the other ship.

Sundas, the eighteenth of the said month, in the eveuing, they departed from this bay of Sau Mateo, and tho Wednesday following, on the trenty-first of the said mouth, they arrived at Puerto te la Posesion, and still obtained no news of their cousort; they waited two days without eutering the hasbor, for they dicl not dare to enter it on aecount of the heavy northrest wind which blew, and, as they parted their cable, of necessity they got under way.

Friday, on the twenty-third of the said month, they doparted from Puerto de la Posesion, and the following Saturdas at midnight they arrived off Isla de Cechos, and being there the followiug Monday, the twenty-sixtl of tho said month, arrived the other ship off Isla de Cedros, at which they rejoiced mueh aud gave many thaoke to God;

this ship passed by La Isla de Jnan Rodriguez, at nigbt. passing through some breakers so that they thought they must be lost, and the mariners promised to go in procession naked to her church and our Lady delivered them. 
CABRILLO.

ULLOA AND VIZCA JNO.

and that night [of the great storm] the flag-ship disapperred; and in five days they ran two huncred loagues, with reefed foreswil, and there was nothing more to eat, but rotten biscuit, aud they dealt out one pound per ration.

Thursday, on the eight of the said month, they departed from El Puerto de San Sebastian, iu search of the other vessel, and the whole crew made their demands that they should return to New Spaiu, as we had nothing that we could eat; and because this was in reason, they ordered the return, searehing for thcir consort.

and they found her by chance at the Isla de Cedros, on the twenty-sisth of said month: 


\section{DAVIDSON.}

mention of the dangers off the northwest shore of San Migucl Island. )

The ships arrive at El Puerto de Navidad, in New Spain, April 14, 1543.

"de Jetra de] tiempo," $i$. e., in an oll manuscript of that period.

\section{FERRELO.}

On Monday, the second day of the month of April, they departed from the Is]a de Cedros on their return to Now Spain, beeause they did not have a snpply ol provisions to renew their attempt to discover the coast. They arrived in El Puerto de Navidad Saturday, the fourtcenth day the said month of April [1543].

Came as Captain of the ships, Bartolomè Ferrelo, Chief Pilot of the said ships, in defult of Juan Rodrignez Cabril]o, who died in Isla do la Posesion. The men came in the said ships.

( ${ }^{1}$ So in the origina], without doubt by equivocation.

(2) He speaks of the port where they auchored in twenty-cight degrees.

(3) An cqual blank in the origiwal.

Fonnd without the name of the author, in the genera] archives of the Indias of Seville, in the writing of the time, among the papers bronght from simaneas. File nine of Descriptions and Popn]ations.

Examined and approved.

\section{MARTIN FERNANDEZ DE NAVARRETE.}

There is another copy of this narrative in the collection of Muñoz, Vol. XXXVI, in which he inserts after his certificate of approval: "At the head and on the cover of this narrative occurs three times, De Jnan Puez."

The differences which aro noticed between the present narrative and that one are: ( $\left.{ }^{4}\right) 3^{\circ}$ and $\frac{2}{3} ;\left(^{5}\right)$ Nor vordeste sudueste; $\left(^{6}\right)$ The last two names are united thus, Quaumugua; $\left({ }^{7}\right)$ Anacoac; $\left({ }^{8}\right)$ Caacac; $\left({ }^{9}\right)$ Xuca; $\left({ }^{10}\right)$ Caco. 
and Satnrdar, on the fourteenth of April, they arrived at the Puerto de Navidad, of the returu vorage, sadness, because to have died in it their Cantain Juan Rodriguez Cabrillo, of infirmity, a good man, and very rell versed it narigation; and for that of this coast theso sailors said that large ships of two hundred tons are necessary, very fast, and well provided with sails, rigging, and eables. and that the sails be from Castile, becanse those from this eountry, split cvery moment, and that they shonld take a large supply of provisions: and that no Indians sionld go, because in the royage they are of no nse, and eat the provisions; and finally these vessels went as far as the forts-four degrees. 
The landfalls of Cabrillo (U.) and Ferrelo (F.), with their names by Ulloa (U.),

\begin{tabular}{|c|c|c|c|c|}
\hline No. & $\begin{array}{l}\text { Dates, } \\
1542,1543 .\end{array}$ & $\begin{array}{l}\text { Name of place by Cabrillo and } \\
\text { Ferrelo. }\end{array}$ & $\begin{array}{l}\text { Latitude by Cabrillo } \\
\text { and Ferrelo. }\end{array}$ & Names by Ulloa, Drake, or Vizoaiuo. \\
\hline $\mathbf{I}$ & $\left\{\begin{array}{l}\text { Juве } 27,154 \ldots \\
\text { Apr. I4, I543.. }\end{array}\right\}$ & El Puerto do Navidad.......... & & El Puerto do la Navidad, V......... \\
\hline 2 & Juno $29,1542$. & El Cabo do Corrientes. & $20,10, C$. & $\begin{array}{l}\text { El Cabo de Corrientes, } V . . . . . . . . . \\
.\end{array}$ \\
\hline 3 & July $2,1542 \ldots .$. & La Punta de California . . . . . . . & 240 "and more," C... & ….................. \\
\hline 4 & (.............. & El Puerto del MIarques del Valle. & .... do ........... & La Babìu do Sauta Cruz, U....... \\
\hline & $\cdot$ & El Puerto de la Cruz........... & .... do $\ldots . . . .$. . & \\
\hline 5 & Juls $6,15+2 \ldots .$. & El Puerto de San Lncas....... . . & $\mathrm{C}, \mathrm{F} \ldots \ldots$ & La lbahì de San Bernabè, V....... \\
\hline 6 & July $\&, 151^{2} .$. & El Puerto de la Trinidad....... & $25^{\circ}, \mathrm{F} \ldots \ldots$ & $\begin{array}{l}\text { La Bulia rle San Abad, U,; La Bahia } \\
\text { de Santa Marina, V. }\end{array}$ \\
\hline 7 & July $\&, 154: \ldots$. & Lil Puntiz dle lia "rinidad ....... & $25^{\circ}, \mathrm{C} ., \mathrm{F}$ : & 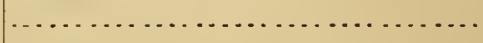 \\
\hline 8 & July $8,1542 \ldots$ & Una Isla. ................... & $F \ldots \ldots$ & 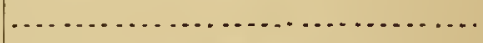 \\
\hline 9 & July $13,1542 \ldots$ & El Pnerto te San Pedro........ & $25 \frac{1}{3}^{\circ}, \mathrm{F} \ldots \ldots$. & El Puerto de la Magdalona, V...... \\
\hline 10 & ................. & La Bahia de San Martin........ & $F \ldots \ldots \ldots$ & La Bahìa de Santa MLarta, V ....... \\
\hline 11 & $\mathrm{Jn}_{\mathrm{y}} \mathrm{S}^{+}, 1542 \ldots$ & Una Gran Enseuacha . .......... & $26^{\circ}, F^{\prime} \ldots \ldots$ & $\ldots$ \\
\hline 12 & Ju!y $19,1542 . .$. & Ėl Puerto dia la Magualena.... & $25^{\circ}, \mathrm{C}, \mathrm{l}$ & $\cdots$ \\
\hline 3:3 & $J n I_{y}-, 154: \ldots$ & La l'unta de Santil Cataliur... . & $\cdots \cdot$ & \\
\hline 14 & $\left.\mathrm{~J}_{1:}\right]_{y}: 5,1542 \ldots$ & El l'nerto de Snutiago ......... & $27 \frac{10}{2}, 1 \ldots \ldots \ldots$ & La Bahia cle las Ballenas, $V$.... \\
\hline 15 & $J n l y-1542 \ldots$. & Habre Ojo.................... & $97+1,1 \ldots \ldots$ & Alurojos, $Y$.'s chart ......... \\
\hline $1 i$ & July,$- 1542 \ldots$ & Punta s Puerto de Santa Auil.. & $28^{\circ}, F^{\prime} \ldots \ldots \ldots \ldots$ & $\ldots \ldots \ldots \ldots \ldots \ldots \ldots \ldots \ldots \ldots$, \\
\hline 17 & $\mathrm{Jul}_{\mathrm{Y}}-, 1542 \ldots$ & $\begin{array}{l}\text { Una Isleta olora de una logma de } \\
\text { Tjerra. }\end{array}$ & $250, \mathrm{~F} \ldots \ldots \ldots \ldots \ldots$ & La [s]a de San Roque, U., V ..... \\
\hline 18 & $\left.J_{n}\right]_{y}: 2,1.12$ & Iil Puerto Fondo.............. & $\mathrm{I}^{2}$ & \\
\hline 19 & July $: 31,154: \ldots$. & {$[$ Anchorage $] \ldots \ldots \ldots \ldots . . . . .$.} & $F \ldots \ldots \ldots \ldots \ldots$ & 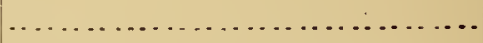 \\
\hline 20 & Aug. $1,1512 \ldots .$. & El Puerlo de San Pelro Viucula. & $28 \frac{1}{3}$, "and more," $\mathrm{F}$. & El Puerto de Sau Bartolonè, V..... \\
\hline 21 & Ang. $2,1542 . . .$. & La Isla rle San Fsteban ....... & $F \ldots \ldots \ldots \ldots$ & $\begin{array}{l}\text { Ia Isla de Natividaul de Nnestra } \\
\text { Señora, V. }\end{array}$ \\
\hline 2 & 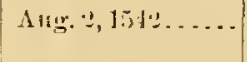 & Una linscuarla Grande .......... & $\mathrm{F}$ & 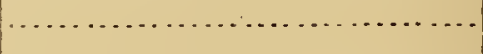 \\
\hline $2: 3$ & $\left\{\begin{array}{l}\text { Ang. } 5,1542 . . \\
\text { Mar. } 2,1,1, \ldots\end{array}\right\}$ & La Islat de Zatross.... & 290,1 & $\left\{\begin{array}{l}\text { La Isla cle los Cedros, U. : La Isla } \\
\text { de Cerros, } Y .\end{array}\right\}$ \\
\hline 24 & Ang. 11, 1513.... & El $1{ }^{\prime} 12 \times t o$ de Siuta Clari ...... & 300, " wrint," $\mathrm{F} .$. & La balia du San Mipulito, V ....... \\
\hline 类 & Aug. $15,154 \% \ldots$ & La Pinta ilel Mal Abrijo ..... & $3010,1, \ldots \ldots \ldots \ldots$ & 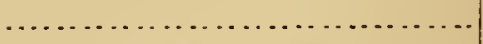 \\
\hline 26 & Ang. 1!', 151:..... & La $\left.I_{i s}\right]$ i de san Berwardo. . . . . . & $3030^{\circ}, \mathrm{F} \ldots \ldots$ & Lil Islil rle San Gerónymo, V........ \\
\hline 27 & $\Lambda 1 \mathrm{~g} .20,15.4: \ldots$. & $\begin{array}{l}\text { El Cabo dal Engaño ........... } \\
\text { La Punta de] Engaño .......... }\end{array}$ & $\begin{array}{l}310, \mathrm{C} \ldots \ldots \ldots \\
310,1, \ldots \ldots \ldots\end{array}$ & 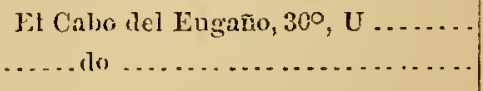 \\
\hline 28 & $\left\{\begin{array}{l}\Lambda u g, 21,134: . \\
\operatorname{Mar} .21,154: 3 .\end{array}\right\}$ & El lanerto dir la Posesion & $3170, \mathrm{l}$ & Ial l3alìa de las Virgines, $V$. \\
\hline
\end{tabular}


Drake (D.), and Vizeaino (T.), and the present names and latitudcs.

\begin{tabular}{|c|c|c|c|c|}
\hline Present name of the place. & Latitude. & $\begin{array}{l}\text { Correetion to C., F., } \\
\text { or D. }\end{array}$ & Remarks. & No. \\
\hline Port Navidad . . . . . . . . . . . . & \begin{tabular}{cc|c}
0 & 1 \\
19 & 13
\end{tabular} & n........ & & 1 \\
\hline Cape Corrientes ............. & 2025 & $-0 \bar{s}^{\prime} \ldots \ldots \ldots \ldots \ldots$ & $\begin{array}{l}\text { It is more than probable that Cabrillo } \\
\text { assumed the latitude as giren by presions } \\
\text { uarigaters. }\end{array}$ & 2 \\
\hline Capo Pulmo ................. & 2323 & - $3 \gamma^{\prime}$ "arid more," C. & (1, & 3 \\
\hline Anchorage under Cape Pulmo... & 2323 & $-37^{\prime}$ "and more," C. & 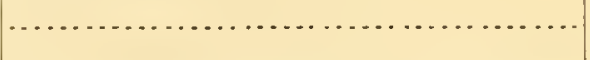 & 4 \\
\hline San Lucas bay ................ & $25: 3$ & ............ & $\begin{array}{l}\text { Cabrillo did not observe tho latitude. } \\
\text { "They say it is in latitude } 23^{\circ}, " \mathrm{~F} \text {. }\end{array}$ & 5 \\
\hline Santa Marina Bay ............ & 2420 & $-40^{\prime}, \mathrm{F} \ldots \ldots \ldots \ldots$ & 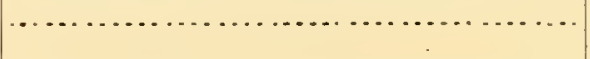 & c \\
\hline Сари Товсо................... & 2417 & $-4 w^{\prime}, \mathrm{C} ., \mathrm{F}$ & The SE. point of Santit Mlargarita lsland.... & 7 \\
\hline Santa Miargarita Island......... & 2417 & ........... & The island is 22 miles long. . . . . . . . . . . . & 8 \\
\hline Magdalena Bay ................ & 2132 & $-58^{\prime}, \mathrm{F}, \ldots$ & 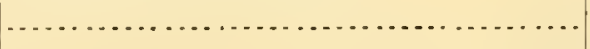 & 9 \\
\hline Santa Maria Bay ............. & 2144 & - & (- & 10 \\
\hline$\cdots$ & ...... & $\ldots$ & $\begin{array}{l}\text { There is no gulf; lut the lowland north of } \\
\text { Cape Lazaro slightly recedes, and would } \\
\text { mislead a navigator in a small resel in } \\
\text { the ofing. }\end{array}$ & 11 \\
\hline Bequeñ. bay and Point........ & 2014 & $-40^{\prime} \mathrm{C} ., \mathrm{k} \ldots \ldots \ldots$ & $\begin{array}{l}\text { Ferrelo sass: "It is } 40 \text { leagues from tho bisy } \\
\text { of Sau Martin to this coast." }\end{array}$ & 12 \\
\hline $\begin{array}{l}\text { San Domingo Point and Anehor- } \\
\text { age. }\end{array}$ & 2619 & $\cdots \cdot$ & ..................... & 13 \\
\hline Ballewas bay .................. & 2645 & $-45^{\prime} 1 \ldots$ & - & $1 \dot{4}$ \\
\hline Abreojos Rocks . . . . . . . . . . . . . & 2646 & $-44^{\prime}+\ldots \ldots \ldots \ldots$ & A dingerous roef of visible and sunken rocks. & 15 \\
\hline Asumeion Point nud Anehorage.. & 2707 & $-53^{\prime} F^{\prime} \ldots \ldots \ldots \ldots$ & 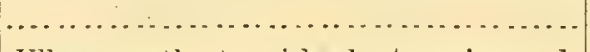 & 16 \\
\hline 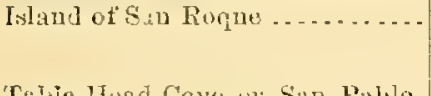 & 2709 & $-511^{\prime} \ldots \ldots \ldots \ldots$ & $\begin{array}{l}\text { Ulloa saw the two islands, Asuncion and } \\
\text { San Rorne. }\end{array}$ & 17 \\
\hline $\begin{array}{l}\text { 'ratio-1Fud Cove: or San Pablo } \\
\text { Bay. }\end{array}$ & 9711 & & 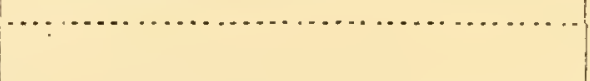 & 13 \\
\hline Bag of Sin Cristoval..... & ...... & $\cdots \cdot$ & ... & 19 \\
\hline Port Sun Bartolome............. & 2739 & $-5 t^{\prime} "$ and more," $\mathbf{F}_{\text {- }}$ & 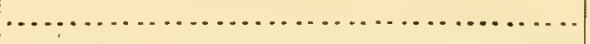 & 20 \\
\hline Nativislat [sland? . . . . . . . . . . & 2753 & .......... & $\begin{array}{l}\text { The Afégua, or Bird Islanca of Father Tara- } \\
\text { val, 1734. }\end{array}$ & 21 \\
\hline Sebastian Yizeaino Bay ......... & $\begin{array}{l}2545 \\
\text { to } \\
2835\end{array}$ & ... & $\begin{array}{l}\text { This is the Gulf of San Iavier, of Father } \\
\text { Taraval. It is } 50 \text { by } 60 \text { uniles in extent. }\end{array}$ & 22 \\
\hline Cerros 1 siand.......... & 2802 & $-.88^{\prime} \mathrm{k}$ & $\left\{\begin{array}{l}\text { They auchorod nuder the south shore. } \\
\text { This is the Analgua, or Foy Islaud, of } \\
\text { Pather Taraval, 1734. }\end{array}\right.$ & 23 \\
\hline Ia P'iaya Maria Bay ........... & 2355 & $-65^{\prime}$ "neant," $\mathrm{F} . .$. & They anchored liere................. & 24 \\
\hline 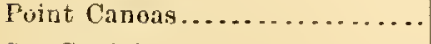 & 2925 & $-65^{\prime} F^{*} \ldots \ldots \ldots \ldots$ & . . . . de & 25 \\
\hline San Gerónimo Island............ & 2948 & $-4 Q^{\prime} F \ldots \ldots$ & {$[\ldots \ldots$ de $-\ldots \ldots \ldots \ldots \ldots$} & 26 . \\
\hline Point Baja .................. & 2956 & $-6 x^{\prime} \mathrm{C} \ldots \ldots \ldots \ldots$ & 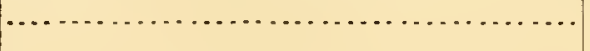 & 27 \\
\hline 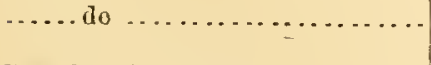 & 2956 & $-6 d^{\prime} \mathrm{F}^{\prime} \ldots \ldots \ldots \ldots$ & (n. & \\
\hline Port San Queutin... & $30: 24$ & $-661 \%$ & . & 28 \\
\hline
\end{tabular}


The landfalls of Cubrillo (O.) and Ferrelo (F.), with their names by Ulloa (U.),

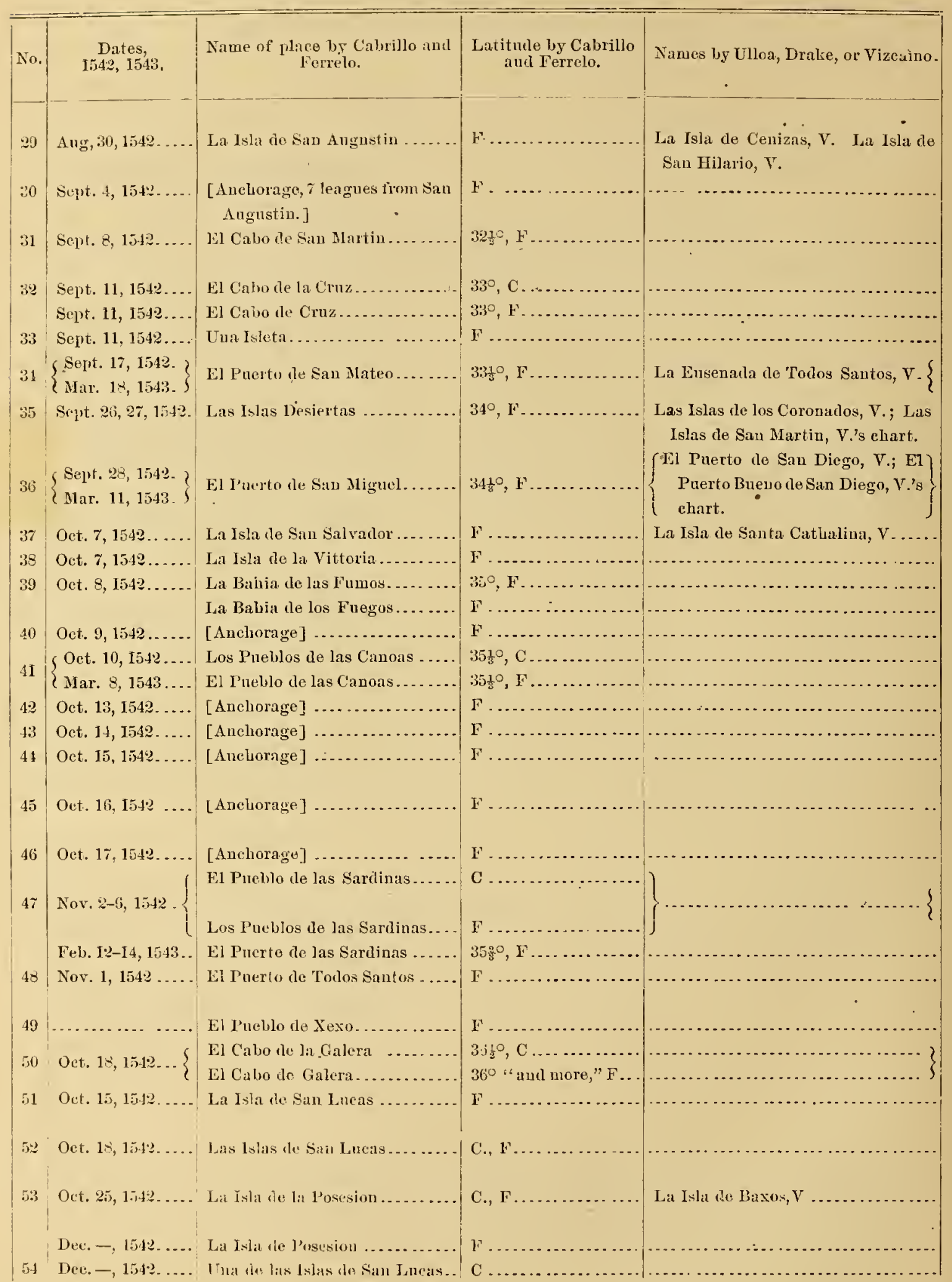


Drake (D.), and Fineaino (V.), and the present names and latitudes-Continued.

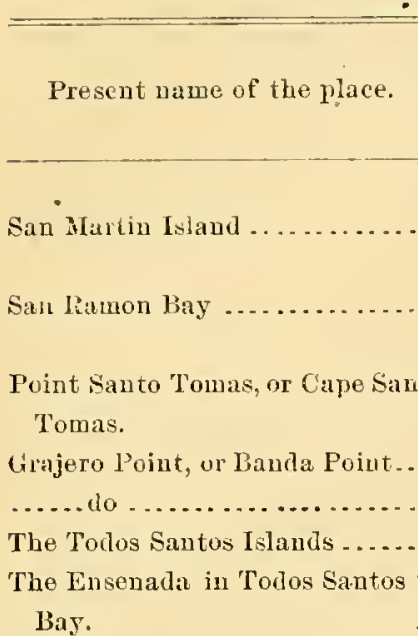

Los Coronarlos Lslancts.

San Diego Bay

Sauta Cataliua Island

San Clewente Island

Santa Monica Bay

......do

The Anchorage off Laguua Mugu .

San Buenaventura.

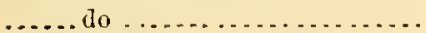

Anehorage otr " tlue Ríncon" ... -

Auchorage ofi" "the Carpinteria".

Auchorage 4 or 5 miles west of

Goleta Point.

Anchorage off the Cañata del Refugio.

Auehorage oft Gaviota Pass ....

Tho Indian Villages at Gaviota Pass.

Anchorage off Gaviota Pass. . .

Anchorage off El Coxo.........

Indian Villaye at El Coxo.......

Puint Concepeion, or Point Con- ? eeption.

The three islands, Sauta Cruz, Santa Rosa, and San Mignel.

San Miguel, and then Santa Cruz and Santa Rosa as one.

San Mignel Island

\section{Latitude. Correction to C., F., or $\mathrm{D}$.}

.

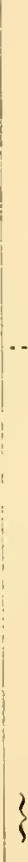
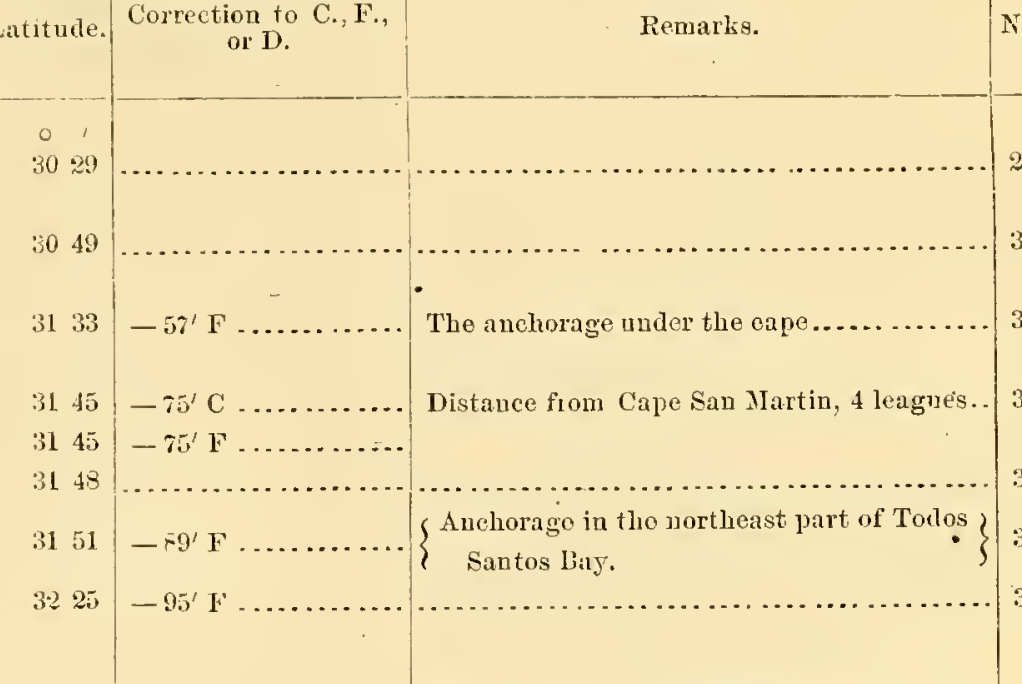

$3240-100^{\prime} \mathrm{F} \ldots \ldots . . .$.

\{He has one of the largest errors in the \} \{ best-known port. 336 $3327 \quad \ldots \ldots \ldots \ldots \ldots \ldots$ At the great depression across the island... 37

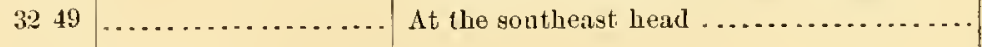

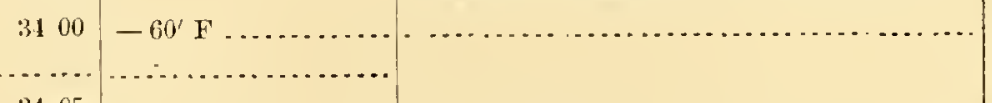

3405

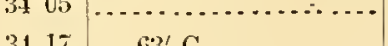

\begin{tabular}{ll|l|l}
34 & 17 & $-63^{\prime} \mathrm{C}$ & $\ldots$ \\
34 & 17 & $-63^{\prime}$ & 1
\end{tabular}

3429

3424

3425

3427

3427

$-633^{\prime} \mathrm{F}$

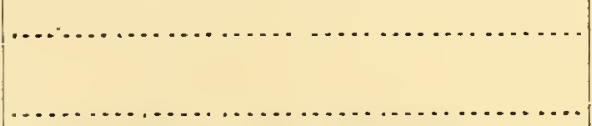

A few miles east of Santa Barbara..........

A feir alles enst ar Sing barbara.

$: 34: 8$

Ferrelo says the Iurlian nane was Cieaeut.

3427

3428

There are two Coxos. Thu Coxo Viejo is one mile east of the noual anchorage El Coxo.

3429

3427

3427

$-93^{\prime}$ " "allet more," $\mathrm{F}$.

$\{$ La Punta de la Concepciou of recent Span-

ish navigators.

They overlap, each uther, and were seen as 5 ono great isiand.

One large-Santa Cruz aud Santa Rosa-and one swall, which was San Mignel.

3403

Ferrelo says the Indian name mas Cigniınиymu.

...... do ........................... 
The landfalls of Cabrillo (C.) and Ferrelo (F.), with their names by Ulloa (U.),

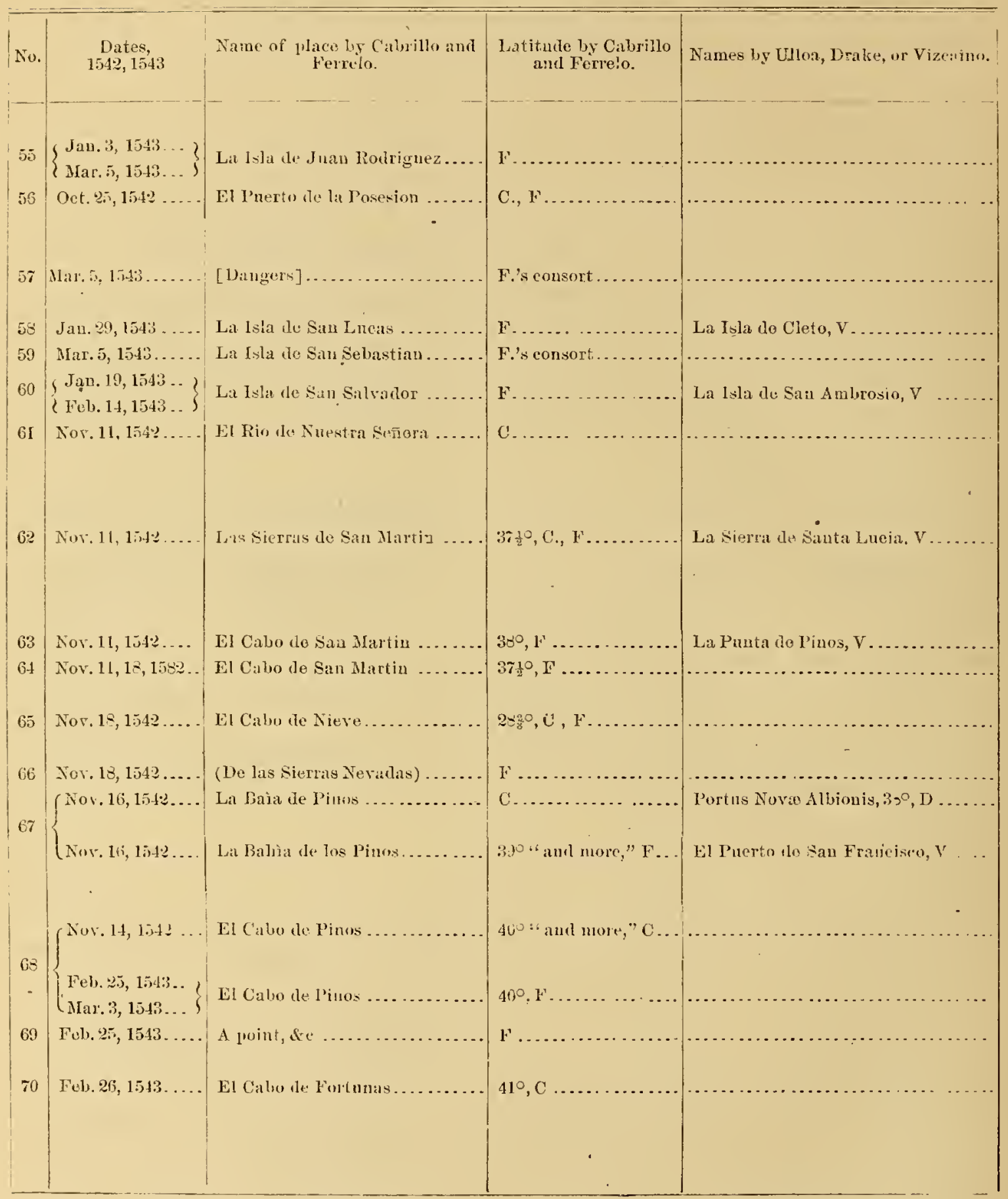


Drake (D.), and Vizcaino (V.), and the present names and latitudes-Continued.

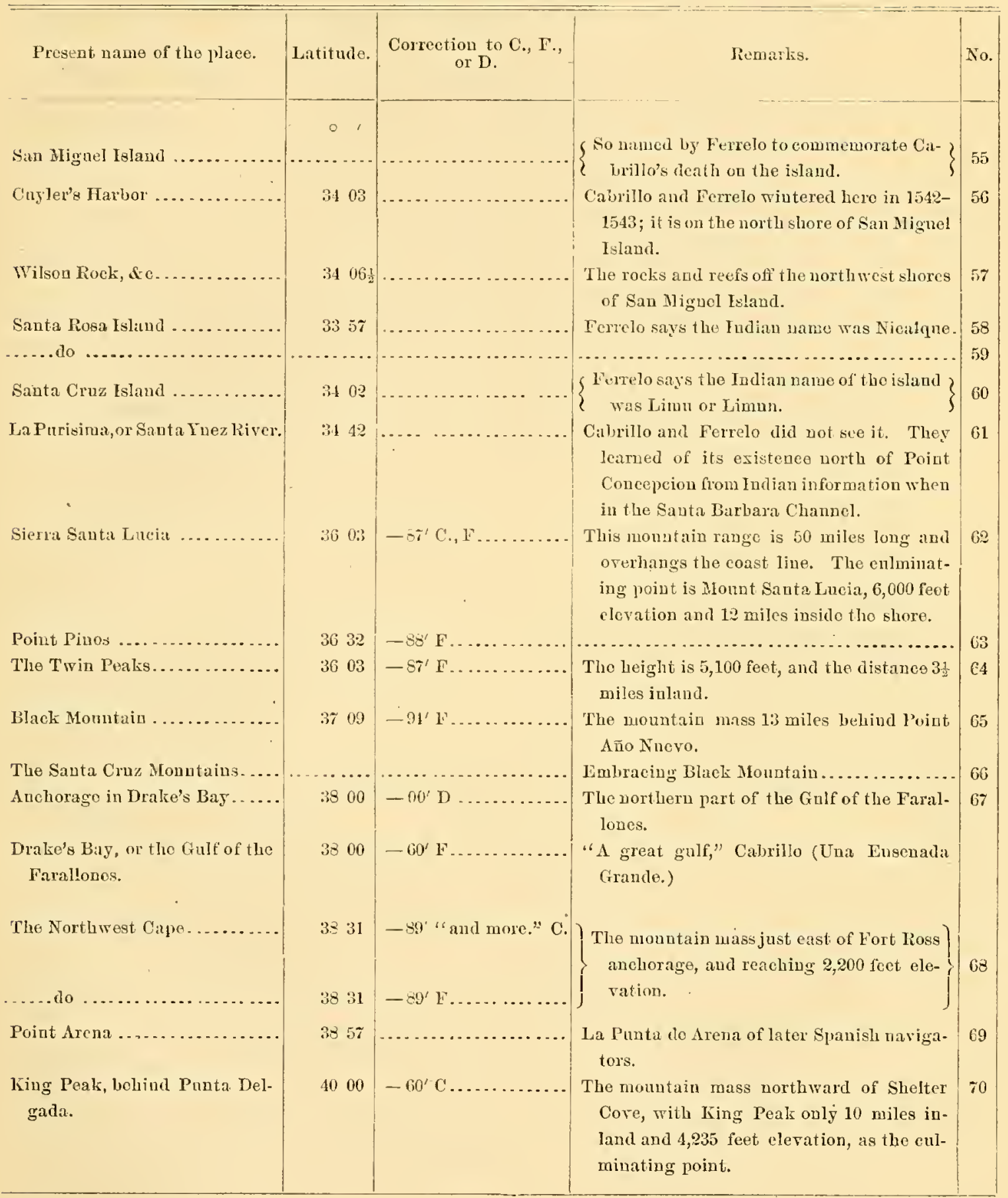





\section{INDEX TO APPENDIX N0. $7-1886$.}

\section{PREFATORY NOIL.}

In consulting this index and the paper to which it relates, it will be of much advantage to refer to the unp (Illustration No. 18) which Assistant Davidson has prepared to show the landfalls of Cabrillo and Ferrelo on the Pacific coast.

The several items of nomenelature and other references, enbracing all appearing in the original paper, are herein indexed in groups, nuder the following headings, for convenience jn collatiug the descriptions; but for a condensed staternent of the names and positions of the places mentioned by Cabrillo and Ferrelo, and which havo been identified by Assistant Davidson, see his table, pp. 24:247.

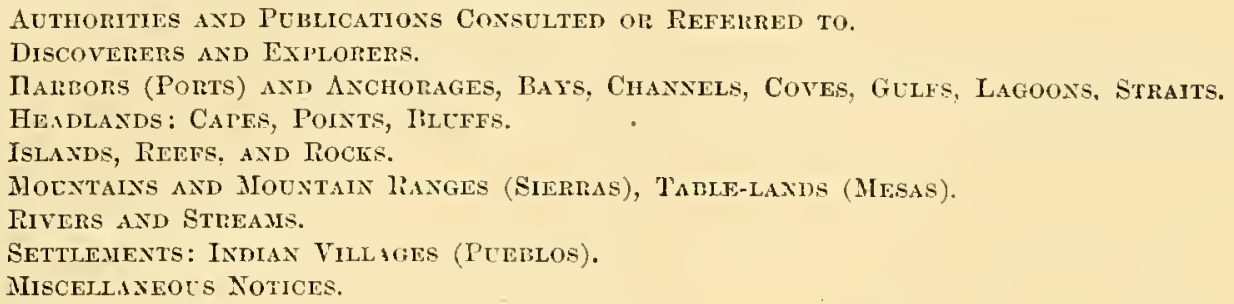

Authomities and Publications Consulted or lifFERRED TO.

[For the full titles of the prineipal pablications aamed iu the introduction, see pp. $156,157,158$.]

Burney: "Chrosological History of Veyages and Discoveries in the Sonth Sea or Pacific Occan."

Cabrillo: In the original Spanish in Herrera, \&c., and in Evans (and Henshaw's) translation.

United States Coast and Geedetic Survey Charts.

Dnited States Coast Pilat of Califo:nia, Oregon, and Washington. Fourlh edition. By George Davidson, Assistant, Uaited States Const and Gcodetie Surrej, 1880.

Drake: "Ihe Eoglish Hero, \&ec." Edition of 1739.

Drake: "The World Eacompassed, \&e." Hakinst Society, 1854.

Ferrcle: In the origioal Spanish, and in Evans" (aud Henshan's) translation.

United Stateg $W_{a r}$ Department: Gcagraplical Surres s $W_{\text {cst }}$ of the one huodredtl Meridian. Fol. VII.

Hakluyt: "Voyages, \&o.," Vol. III.

Henslaw: Introluetion to Evaos' translation of diaries of Cabrillo and Terrelo.

Herrera: "Mistoria General, sc.," for royages of Cabrillo.

Hondius' Map of Drake's Vorage. (Sec under Drake.)

Hydrographic. Burean of the Uniteri States Nary; description of the "TW est Coast of Mexico, \&ie."

Kohl: History of Discorery aod Exploration oo the Coasts of the Uoited States. In Report of Snperintendent United Statos Coast and Gealetio Surrey fur 1884 .

Mnoez: Narrative of Fertelo's Toyages. Sec p. 210 of this paper.

Navarrete: Narrative of Ferrclo's Vojages. Sice p. 210 of this paper.

Ramusio: Account (in Italian) of Voyages of Ulloa, S.e., and Englis translation is Hakluyt.

'Cebenkoft: $\amalg$ rilrographic description (Atlas, 1818). See Pp. 181, 200 of this paner.

Torqnemuda: Hsarograpbic tescription. See pp. 178, 182, 186 of this paper.

Vlloa: Is Ramnsio (see abore), and trasslation iato Eaglish in Hah. luyt.

Veneras: "Noticiarle la California, se.." the original nsed for" $\mathrm{Vj} z_{*}$ caibe's Vejares.

Vizcaino: In Venegas (eriginal), and Vizcaino's chart of the coast. as exlibited in Bnrney's volnmes, Part II (sec abore).

\section{Discoverers AND Explorers.}

[Names to bo fonod generally thronghout this paper for tho perior in qnestion." For those casnally allnded to, see pages as noder.]

Beechey ................................... Page.

Cabrila ........................................

Cook. . . . . . . . . . . . .

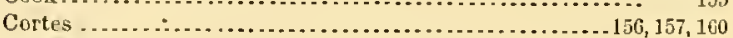

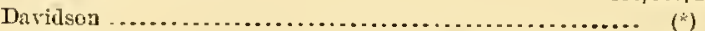

Drake .................155, 156, 157, $158,214,216,218,219,246,247$

Ferrele ........................................ (i)

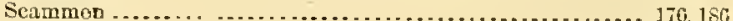

Taravel..................................... 155, 176, 192, 191

Dllaa ........................................... * (*)

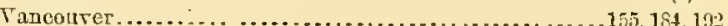

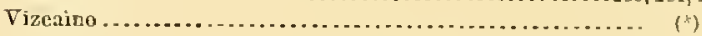

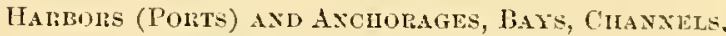
Coves, Gulfs, Iagoovs, Straits.

A lad, Bahia de San ........................... 104, 165, 24-3

Aza, Pnerto de Santa.............................. 170

Anehorage at $A$ snuciou Point ....................... 243 in Bay of Sav Cristeval . ..................... 242, 243 off the Canata del Refugio................... $-41,245$ under Capo Pnlmo........................ $\quad 243$ off the Carpinteria ........................... 24t,245 in Drake's Bay ............................ 247 off El Coxo ............................... 245 efr Fort Ross............................ off Gariota Pass ............................ 24, 245 west of Gaieta Point ...................... 245 off the Rincon. ............................ 244, 245

(Eor other ancho:ages, see the condensed table)

Ballenas, Balii. de liss ............................16飞, 169, 242 Ballenas Iity (near Drilko's Bizy, cailed after Volabos (Bola-

nas), Vizenino's pilot) ........................... 218 Bartolomè, Puerto de Sau............................. Bay of San Cristeval............................... 172,243 Bizy of Saz Quentia ............................... 156 Bay ot the Virging...................................... 182 Becher's Bay (oa Santa Rosa Island) ................... 223 
Puge

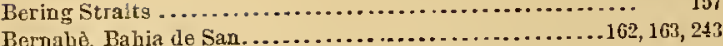
Beruabè, Bahia de San................................

Blanco Day ....................................... 178

Blaneo Day ............................................... ${ }_{220}$

Caña dei Refagio ...............................204, 841,245

Caual do Santa Earbara (Sauta Barbara Channel) .........198, 200, 201

Canoas, Prerto de las ..................................... 238

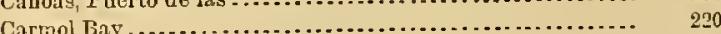

Chetko Bay (an anchorage of Drake) .................... $\quad 232$ Christoral Babia do Sitn .............................106, 167, 24? Clara, Paerto de Santa................................. 178, 242

Colnett Bay ...................................... 188

Crescent City Harbor.................................. 232

Cruz, Babia de Santa .

Cruz, Puerto de la (or de Sintâ) ......................160, 101, 243

Cuyler's Harbor (on San Miguel Island) .........206, 226, 23t, 238,247

Descanso Dny..................................... 192 Diego, Puer to Bueno do San (or El Ducno Puer to) .. $\} \quad$ 192, 193, 124, Diego, Puerto de San (= Pnerto de San Miguel).. $\}$ 195, 238, 241,245 Domingo, Boca de San................................. 160 Drake's Bay (Portus Noviu Albionis) ....156, 214, 216, 218, 219, 222, 247 Diake's Lamoon (or Estero dle Limancourt) ..............214, 216, 218 Enseñadil Grande (of Ferrelo), (Gulf of San Xarier of Tar-

avel), (Dar or Gult of Sebastian Vizcaino) .........176, 194, 242, 243 Estero Americano (in Bodega Bay) ..................... 220 Estero de Limancout (or Drake' ${ }^{\prime}$ Lagoon) ...............214, 216, 218 Estcros Bay...................................... 210,211 Falso Day (seo San Diego Lay) ........................ 192, 19 False Bay (uear Maria Point) .......................... 178 Falso, Puerto (north of San Diego Bas) .................. 19 Faralloncs, Enseũada do los (of later Spanish authorities) .. 214 Farallones, Gulf of tho (U. S. Coast and Geotietic Snrrey), $214,222,240,247$ Fondo, Pnertol- 17:, 212 Fort Ross Coro................................... 2g2, 299 Francisco, Puerto de San (of Tizcaino; and Drake's Bas) ...214, 215 $218,219,246,247$ Fuegos, Bahiz de los ................................ 190, 244 Fnmos, Bahia de los ..............................19 196, 194 Gaviota Pass....................................... 204, 208 Golden Gäte. 218 Gulf of the Farallones (of the U. S. Coast and Geodetic Sur-

rey) ....................................... 214,222, 246, 247 Ifalt Moou Tay ...................................... 214 Hassler Core......................................... 180 IIipolito, Sahia do San .......................170, 171, 178, 170, 242 Humboidt Bay.................................... 230

Isla de San Sal vador, Puerto de la ....................... 230

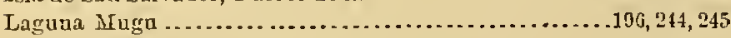
La Playa Maria Fay .................................. 178, 24, Lneas, Pnerto de San .............................. 162, 243 Mlagrlalena, Babia (or Puerto) de la.... ................. 164, 249 Nagdalena Bay ...................................164, 106, 243 Magtalena, Pnertı) (or L3alia) de la..................... 161, 242 Mansanilla, harbor of ............................... 160

Mariua, Eahia de Santa................................. 105, 249 Marques del Valle (titlo of Cortes), Puerto del.............160, 161, 242 Marta, Bahia de Santa Martio, Bahia de San.........................164, 165, 166, 243 Mateo, Bahia de San.................................. 238 Mateo, Puerto do San ...............................190, 192, 241 Mazatlan, barbor of .................................... 161 Miguel, Puerto de San (San Diego Bay) ................102, 238, 244 Mouterey Ilarbar................................... Monte.Reg, Puerto do.............................. 212, 21 Morro Bay ........................................ 210,211

Navidad lort ........................................ 243 Narillad, Puerto de (of Cabrillo and Ferrelo) ........? 157,160, Navidad, Puerto de la (of Vizcaino) ............... \} 101,240,241,242 Notro Albionis Prrtue......................156, 214, 216, 246, 247 Ona, La Bahia (corruption of La Ballona)................... PaZ, Pllertn do la...................................... 160 Pedro, Prncrto de San................................ 161, 242 Pedro Vincula (Puerto to San) ....................... 172, 242
.... 232, 234

บี Bay....................................164, 160, 243 Pinos, Babia, or Bala, de los (Gulf of the Farallones) .. $322,223,246,247$ Port Naridad....................................... 160, 243 Port Orford ....................................... 232 Port San Eartolome.................................. 172, 178, 243 Port San Quentin...............................18f, 180, 238, 243 Portus Novx Albionls........................150, 214, 210, 246, 24i Yosesion, Puertn de la (on San Miguel Island, now Cuyley's

Marbor.................................206, 207, 22G, 246, 247 Posesion, Puerto de la (now called Port San Quentin) .... 184, 186, $238,242,243$

Queutin, Pntt San..........................184, 180, 238, 242, 243 Rosario Bay ........................................ 184 San Cosme y San Damian, Ensoñada de................ 178, 179 San Cristoval Bay ................................... 172, 243 San Diego Bay .................................... 192, 238, 245 San Hipolito Eay . . . . . . ........................... 170 Sau Ignacio Lay .................................... 168

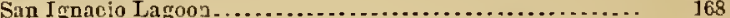
San Jose del Cabo (ile San Lucas, station for transit of Venne,

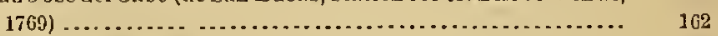

San Luis Obispo Bay ............................... $\quad 210$

San Lucas Bay .................................. 169, 243

San Migucl Passago ................................... 238

San Pablo Bay (or Table Head Cove) .................... 172, 243

Sau Pedro Bay...................................... 194, 196

San Tamon Bay................................... 186, 188, 245

San Roquc Bar . . . .

San Situeou Bay..................................... $\quad 210$ San Simon y Judes, Jahia do :........................188, 189, 191 Sauta Harja Bay .................................. 164, 243 Sinta Miriua Bay ................................164, 16; 243 Santa Honica Bay................................. 194, 106, 244 Santa Tosalia Bay ................................ 1 is Sautiago, Puerto de .................................. 168, 242 Sardinas, Puerto de lag.........................208, 210, 227, 298, 244 Scammon's Lagoon .................................... 178, 186 Sebastian, Puerto de San .......................... 160, 239 Sebastian Vizcaìno, Bay or Gulf of (the " Enseñada Grande"

of Ferrelo) ....................................176, 194, «42, 243

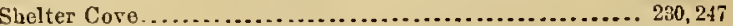
Sheiter d Covo (of U. S. Caast Survey, nnder Cape Tomae). 190, 245 Sir Francis Drake' $\theta$ Bay (see Drake's Bay) .. 156,214,216,218,219,222, 247 Smurglers' Core ........................................ 236, 238 Sontu bay (of Capo San Augustin) ................... 174 Todos Santos, Puorto de............................208, 244. 245 Tndus Los Santos, L̇useñada de................186, 190, 101, 238, 244 Tomales Bas (Tamales on some old Spanish charts) ........ 220

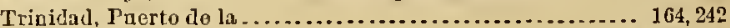
Virgines, Dabia do las...............................184, 187, 242 Javier, Bahiı do San ................................176, 194, 243

\section{IItadlands: Capes, Points, Bluffs.}

A hreujos Point ................................166, 168, 169, 170 Ana, Punta de Santa.............................. 170,242 A й Nuero, Point ................................... 214, 224

Antonio, Point SaI ................................ 180,182 A rena, Point ...................................... 222, 24"

Arena, Punta de.................................222, 228, 247 Arguello, Point................................... 204, 206, 203 Asuncion Point.................................170, 172, 248 A urastin, Cako de San .............................. 174, 175 Angustin, Cape San ................................. 174 Baja, Point (or Punta), near Rosario Bay............182, 184, 242, 248 Ballenas Toint................................... 214 Gallast Point (in Sau Diego Farbor) ..................... 194 Banda (or Grajero) Point ...........................188, 190, 845 Black Point ..................................... 178 Blanco, Cabo (of Flores, Vizcaìno's pilot) ................. 234, 235 Blanco (or Orford), Cape............................... 234 Eluff Print (se日 Caho del Enguĩo of Vizcaìno) ........178, 190, 182, 183 Ca.ifurnia, Pnnta do . ..................................160, 161, 243 Cauoas, Print................................178, 1S0, 182, 243

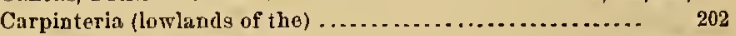
Catalina. Punta de Santa ............................160, ]68, 248 
Page.

Colnott, Cape

Concepcion (or Couception), Point.................. 200, 204,

Concepcion, Puata de la (of recent Spanisb navigators) $\} 206,206,224,245$

Corrientes, Cabo do................................160, 161, 24?

Corrienteg, Cape ................................. 243

Corsa, Cape...................................... 104

Delgada, Poiut...................................... $\quad 230$

Di lgala, Pnnta........................................ 247

Dits:e, I'vint.................................... 196, 199

Engaบ̃o, Cabo del (of Ulloa, Cabrillo, and Ferrelo) .......180, 184, 185 Engaūo, Cabo dul (of Vizesłıo) ......................180, 181, 183

Eugaño, Capo..................................... 181

Engaน̃o, Toint (or San Antonio) …................... 180

Eugaño, Punta del............................... 184, 242

Lugeuio, Point ...................................... 176, 178 Ergenio, Punta do San ...........................172, 176, 178

Falso, Capo (near Cape Toscol........................ 16.

Ferrelo, Cape (Damed so by U. S. Coast Surrey' .......... 155,232

Fortunas، Calo de .................................228, 229, 246

Galera, Calso de....................................... 24.4

Galera, Cabo de Ia .......................204, 205, 206, 208, 209, 210,214

Gold Bluffs ..................................... 233

Goleta, Foint ..................................202, 204, 245

Gorda, Cape ...................................... $\quad 230$

Grajero (or Batuda) Point..........................188, 190, 245

IIipolito, Point San ............................... 170

II uenemo Point .................................... 198, 200

Lagoon Пlead (in Subastian Vizcaino Bay) .............. I I

Lasuen, Paint..................................... I94

Lazaro, Cape San ..............................104, 166, 243

Lazaro, I'uuta do San ............................... 160, 167

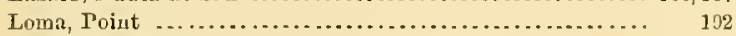

Loma, Punta de la ................................... 191

Lucas, Cape San .................................. 155

Mack's A reh ................................... 232

Mul Abrijo, Tnoti deI ........................... 178, 242

Maria Point .................................. 178

Marques, Point del ................................. 163

Martio, Cabo de ................................ 212, 224

Martiu, Cabo do Sau ...............188, 190, 210, 212, 220, 224, 226, 244, 246

Mendocino, Cabo................................. 230, 231

Mendocino, Capo................................. 230, 231

Miguel, Capo San (or Sansal Point) ..................... 190

Мотго Негтов0 ................................... 17

Morro Redondo ...................................... 161, 165

Mugu Point ...................................... 198

Niere, Cabo de (Snowy Cape of Ferrelo) ...........224, 225, 226, 246

North trest Cape (of the Russians) ....................222, 224, 247

Orford, Cape (or Cape Blanco) ........................... 234

Orford, Point ...................................... $23 ?$

Pablo, Poiat San .................................. 172

Teniosula, tho (in San Diego Harbor; formerly known as

"The Island") .................................. 194

Pegư Poiat....................................... 243

Piedras Blaneas...................................... 210

Pinos, Cabo do ..................................222, 228, 236, 246

Pinos, Point .................................. 212, 247

Pinos, Punta (or I'a. de los, of recedt charts) ...........212, 213, 246

Pulmo, Cape ..................................... 160, 243

Purisima, Point.................................. 208

Quentin, Cape San ............................... 184, 186

Quentin, Point San.............................. 184

Redondo, Cape (see Mrorro Redondo) ..................... 164

Riyyes, Point...............................155, 214, 216, 218

Royes, Puta de los.................................218, 219

Tineon, El (Point Rincon) .......................... 202

saint George, Point (possioly Cabo Meodocino, of Vizcaino) $\quad 230$

Sal, Point..................................... ${ }_{208}$

San Dorningo Point ...............................166, 168, 213

San Roque Point ...................................... 172

San simnu y Judes, Cabo de .......................... 183

Santiagn, Punta de................................... 168

Sausal Point .......

Sebastian, Cape (named so by U. S. Const Survey) ......... 293

Sebasianu, Cabo Blanco de San ........................... 232, 233

Solitarios, Point of.
Page.

Tomas, Cape San ..................................... 1\&s, 214

Toinas, l'vint Sado ................................188, 190, 245

Tosco, Cape .................................163, 163, 166, 243

Trinidad Head ....................................... 232

Trioidad, Punta do la..........................162, 163, 16t, 242

Virgines, Punta de las ................................ 184

\section{ISLANDS, REEFS, ANI ROCKS.}

Abrcojos (Tilbre Ojo), Racks, or Reef ...........168, 169, 171, 242, 24; Alégua (ar Bird) Island ........................... 172, 243 Amalgna (or Fog) Islund .................................. 174, 243 $\Delta$ mbrosio, Isla de San .............................. 202, 246

Anacapa Island (Eaveeapah of Vancourer) -.............. 200, 202 Arena, Isla de ...................................... 194 Assumpeion, Isla do la ................................ 170, 171

Asuncion Island .................................... 170, 171

Augustin, 1s]a de San................................. 186, 24t

Barbara, Isla do Santa .............................. 198, ,09

Bnxog, Isln do . .................................... 206. 226,245

Bcruardo, Iala do Săt........................... 182, 184, 24:2

Birul (or Afémua) Island ............................ 172, 243

Carolinas, Isla do las...................................

Catbalina, Isla de Sinta ............................194, 195, 244

Cedros, Isla do los . . . . . . . . . . . . . . . . . 174, 175, 185, 238, 239, 240, 224?

Cenizat, Ista de .......................179, 182, 183, 184, 186, 187,241

Corrus, 1sin de ............ 174, 175, 182, 183, 184, 185, 192, 194, 258,243

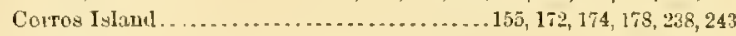

Ciquirauymu (Indian name of San Miguel Isiand) ...... 206, 226, 245

Cleto, IsIi de .................................. 206, 228, 246

Corouados, Islias te los ............................... 199, 193, 244

Deadman's Island (El Mo: ro of San Pedro Ba5) .......... 196, 210, 211

Desiertas, I as Islas ................................... 192, 244

Dolores, Los ...................................... 176, 192

Dragon Rocks (ar St. Geor.te's Reef) ................... 230, 232

Esteban, 1sla do San ............................172, 174, 242

Farallones de Ins Frayles............................214, 218,290

Farallones Isiands: tbo Nortb, t be Middle, the Southeast... 2t.8, 220

FJat Lock (south end of Natividul Island) ................ 174

Fog (or $\Delta$ ntaloua) Island ........................... 172, 243

Fraylos, Los (Farallones de los Frayles) ................. 218

Guadal upe Island (or Isla do Pasaros) ..................... 182, 187 Gernnymo, Isla de Sau.........................180, 182, 183, 249 Hilario. Isla de San ...............................186, 189, 24! Isles (or islauts) of Saint Janes (of Drake), the Farallones.. 218, 219 Limu (or Limun) Indian uaro of La Crnz Island ........... 226, 247 Los Coronados Islands ............................. 192, 193, 244 Lucas, Islas do San (Santa Cruz Istand and Santa Toza

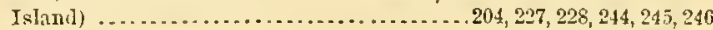
Jrartin, Islas de San ............................. 192, 193, 244 Jiorro, EI (Deadman's Island) ................... 196, 210,211 Tatividad (do Xiuestra Seบ̄ora, Is]a de) ..............172, 175, 102, 242 Natividiad Is]and ..........................155, 174, 178, 189, 243 Nicelquo (Imlian name of Sinta Iiosa Is]and) ...........226, 228, 247 Paxaros, Isia də (Guadalupe Islaud) ..................... 18?, 1 , Posesion, Isla de .................................28, 244 Posesion, Isla do la (San Mfiguol Island) ..206, 226, 227, 236, 244, 245, 247 Redding Fock (near Trinidad Head) .................... 230 Rodrigucz, IsIa do Jnan (San Miguel Is]add) ..... 206, 226, 236, 238, 246 Toque, Isla de San ............................. $170,171,242$ Sacramento Reef.................................. 182 Saiut Georgu's Reef (or Dragon Ivocks) ................. S920, 232 Salvador, Isla de San (Santa Catalina Island) ..... 194, 226, 228, 244, 216 San Benitus Islands .............................. 176, 178 San Clemente Island....................... 194, 190, 200, 241,245 San Geronimo Island ............................... 18?, 249 San Flilario lsland ................................. 189, 187

San Mirtin I*land ............................182, 186, 187, $24 \overline{5}$ San Migucl Ialand (Isla de la Pusesion) . . .... 196, 200, 204, 206, 226, 227, Sia Nirolas Islantl . . . ............................... 198,200

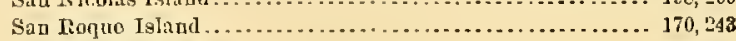
Santa Barbara Island............................... 198, 20

Santa Barbara Cbannel, islands of the .................. 200 Santa Barbata Islands ............................... 200,888 
Page.

Santa Catalina Island ..........................194, 196, 20€, 210,244 Sant a Cruz Island .....................202, 204, 226, 228, 236, 238, 215, 247 Santa Margarita Island................................ 164, 243 Santia Trosa Island ..............196, 202, 204, 206, 228, 236, 238, 245, 247 Sebastian, Isla de Sas ...............................228, 236, 246 Todos Samtos, Islas de ............................... $\quad 190$ Todos Saatos Islands ..................................190, 101, 245 Vittoria, Ista de (is San Clemento Island) ................192, 244, 245 Whale riock (oge of tho Abréjos Rocke) ................ 168 Wilson's Tieef, or Roek ................................ 236, 247 Zedros. Isla do ...................................172, 174, 178, 242

Mouxtaxs a.d Movitain haxges (Sierras), TabliIAANDS (MESAS).

Black Mronutain .......................................... 214, 224, 247 Cone Monntain (or Twin Pcake) .....................210, 21य, 247 Devil's Peak (Mount Diabio) ............................. 201 Fire Hummocks (of peninsula at Cape San Quentin) ....... $18 t$ King Peak ... ...................................... 230, 247 Loma, La (in San Die go Harbor)..................... 193 Joma Pricta (of San Francisco Peninsula Rangc) .......... 224 Mesa de la Cena (Table Moustain) ..................... 192, 193 Mesa kedonda (or Mesa do la Cena) ..................... 192, 193 Mresas belind Point del Mrarques . . . . . . . . ............... 162 Mesas de Saロ Cypriano ................................. 180,181

Miraflores (in Sierra la Victoria) ....................... 160 Morro Hermoso (Sierra Pintada) ...................... 173, 176 Mouot Bacbe (of San Francisco Peajusula Rasge) .......... 224 Mount Carmel ....................................... $\quad 212$ Nount Liablo (Deril's Peals), on Santa Cruz Island........ 204 Arount Pierce ........................................ $\quad 230$ Mount Santa Locia.................................. $\quad 247$ Mount Tamalpais ...................................... 214, 222 Mount T'iresome (in Siorra del Enfado) ................. , 163 Peninsula of Sau Fraocisca............................ 224 Pino Monntain .................................... $\quad 210$

Rocky Butte ....................................... $21_{0}$

Ross Mountain ...................................... 220

San Francisco Perinsula Range......................... 224

Santa Clara Mouataine ............................... 176 Santa Crnz Mountains (Sierra de La Cruz) ................ 224, 24T Santa Foez Range ................................. 208 Sierra del Enfido .................................. 163 Sierra do $l o s$ Siete Infantes ............................ 170, 171 Siciтa de Santa Lucia (now Sierra Santr Lacia) ..........210, 211, 220, $224,246,247$

Sierra la Victoria .................................. 160

Sierra Pintada (Morro Heroioso) ..... ................. 173, 176 Sierra Santa Hooica (aad Sagta Clapa Valley) ............ 196 Sierras de San Martiu ............................210, 211, 246 Sierras Teralas (of Ferrelo), Sao Fraociseo Peniusula

Mouatains ....................................... 294, 246 San Pedm Hill . . . . . . . . . . . . . . . . . . . . . . . . . . . . . . . 196

Sombrero Peak .................................... 180 Table Heal ....................................... 172

Table Mountaio of Beecbey) (see Tamalpais)............ 214, 223 Table Jlonatain (Mesa de la Cena) ....................... 192, 193

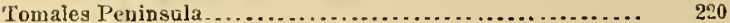
Irin Peaks (or Code Monntain) ...................210, 21:3, 247 Vigia, La ...................................... 202

RIVElS AND STRE IMS.

Aroso Carmen 190 Carmelo, Rio de .................................... . 212, 213 Caınel River........................................ 212, 213 Carpofero, Arroyo de San........................... 224 Chetko River .................................232,234, 236 Crescent vity, river at.................................. Lel Rirer ............................................ 230, 236

Estero Amerícano (in Bodoga Bay)....................... Fistero de Limantivur (or Drake's Lagoon) ..............214, 216, 21 Humboldt Bay, river at............................. 236 Klamatl River....................................
Page.

Irad liver....................................... 230, 236 Nuestra Señora, Tío de (Pnrisima River) .............210, 211, 246

Pigenn River....................................... 230, 236

Pistol Rirer ....................................... 236

Purisina (or Sauta Yuez) River ....................208, 210, 24i

Rio Graodo do Sevastian (mistake of Vizcaino), probably $\mathrm{cd}$ -

triace to Towales Bay .............................. 220 Rocruo River ........................................ 234, 236

Russian (or Slavia aski) Rirer....................... 220

San Buenaventara Riror.............................. 198

San Rosario liver ................................. 182

Sinta Clara Rirer ................................... 198

Santa Y nez Tiver (Parisima Jiver, now so ealled).......... 208

San Viceato Rirer .................................. 188

Slavianski (or Russian) River........................ $2: 0$

Smith's River.................................... . 234, 236

Wiochnk River...................................

\section{Settlements: Indiax Villages (Pueblos).}

Pueblos or villages of Indians along tho shores of Santa Barbara cbanoel and islaoủs (rery populous, erenteen rillages in a distance of 11 mles); references to and-names of somo given ..... I84, 185-198, 205, 208-210, 226; 228, 244, 245

Villages on shores of Drake's Bay and in Nicasio Valley to eastward ..........................................216, $217,: 18$ Pueblos do las Canoas (site of Mission of San Buenarentora) ................................198, 199, :00, 244, 245 Pucblos at EI Coxo (pueblos de Jexu, two villages) .....208, 210, 240,

Indian province of Xucn, oг Sejo...... 208, 210 P'ueblos de las Sardinas, at Gaviota auchora ${ }^{2}$.......... 208, 200, 210, $2: 8,244,245$

\section{Miscellaneot's Notices.}

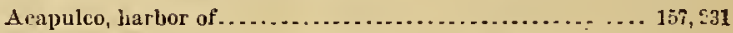
Aguilar, Alferez MIartin, comroancier of the tender to Vizcaioo ............................................... Alaska ............................................... 155 Amadis de Gaula: Namo California first found in this romance ....................................... 150 Anian, Straits of: Mythical, probably Bering Straits....... $15 \pi$ Archises of the Indias of Seville....................... 240 Baneroft, H. II ...................................... 157 Bering Straits ......................................... 157 Bernal Diaz del Castillo: Nemoir ................... 156, 157 California:

Name first found in the romance of A nadis of Gaul .... 156 Lower (Brija), dotermined to be a peninsula by Ulloa ... 157 Upper (1]ta), name applied to region north of San Diego 157 Carolinas, Isla de Yas: Name applied to Lower California... 157 Cavendish, Captain ..................................... I62

Clappe, A uterocho de la: Freach obscr ver of transit of $\mathrm{Ve}$. bus (1760), near Cape San Lineas ........................

Charles II, Kiog of Spinin: The Isla de lis Carolinas named after him ........................................ 157

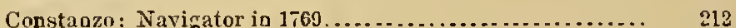

Doyle, J. T ...................................... 157

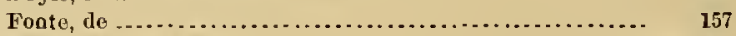

Fort Ross (Rngsian) ............................212, 224, 236

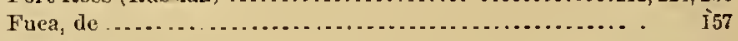

La Paz . . ........................................ 191

Maldonato...................................... 157

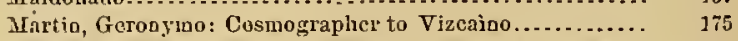

Mendoza, Don Antonio de, Count of Monte-Rey, Viceroy, successor to Cortes .........................156, 157, 161,184, 213 Mexico, or New Spain ................................. 156, 185

Mlissioos, sites of (future) :

San Buenaveatura . . . . . . . . . .

Sato Turuas................................... 188

San Vicente.................................... 188

Molera, E. T'...................................... 157

Montalvo: Translator into Spanish (in 1510 of the Amadie de Ganla (from the Portugnese) (see full title)............ 
Page.

Qaanhuitua, resilesce of wife of Cortes at

Sauta Cruz: A port visited by Cortes and Ulloa............

Iranumine: Indian name for the present Haeneme........

Zuvig̣a, Conde de Mionte-Rog .........................

Pilots on the royages:

Cermenon (215), Fesmandez (161), Ferrer (Ferrelo) (161), Flores (3)i), Volanos for Bolauos) (218), Ximenes (160).
Ships of the explorers:

Patge. Of Ferrelo (2): The San Salvalor (the "Capitana"), La Vittoria (the "Almiranta") ... Of Clloa (2): The Santa Agueda, the Trinidad............ 185 Of Vizeaino (3): The "Capitana," the "Fragata" the "Almirenta"

171,183 

. 




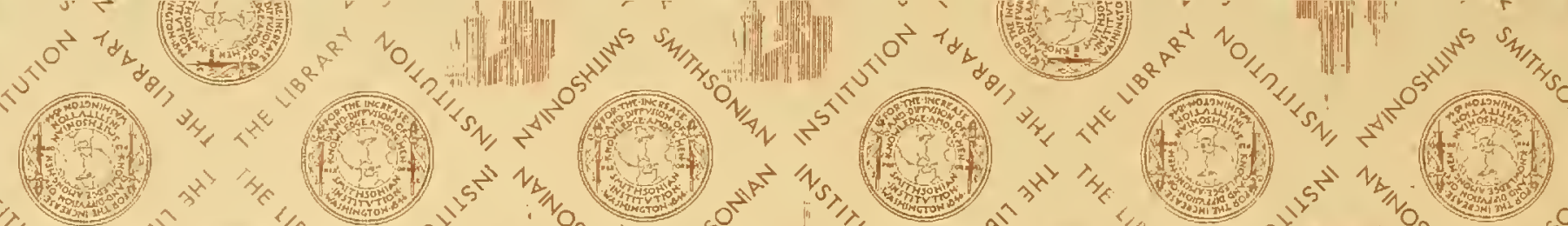

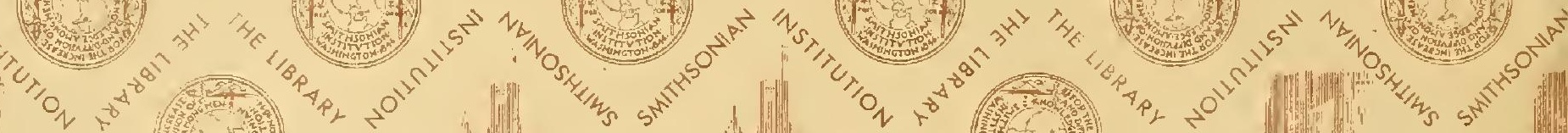

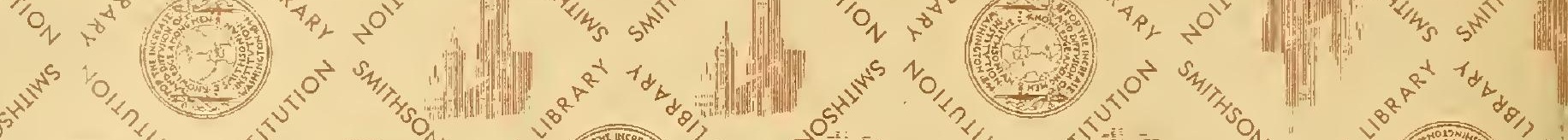

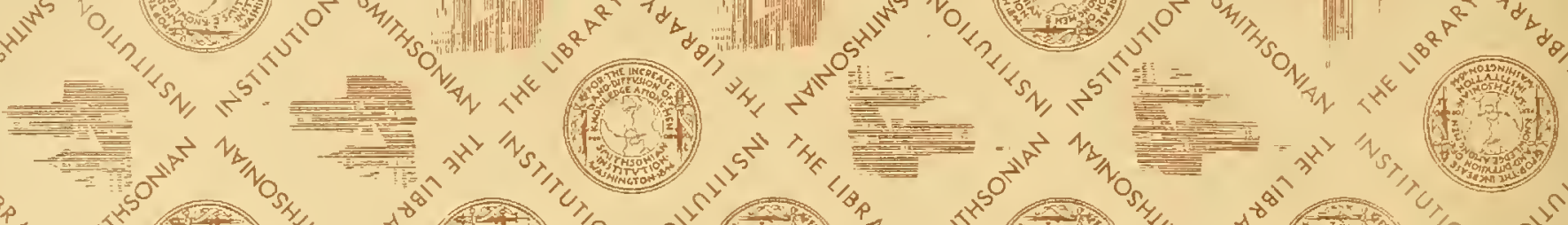
(1)

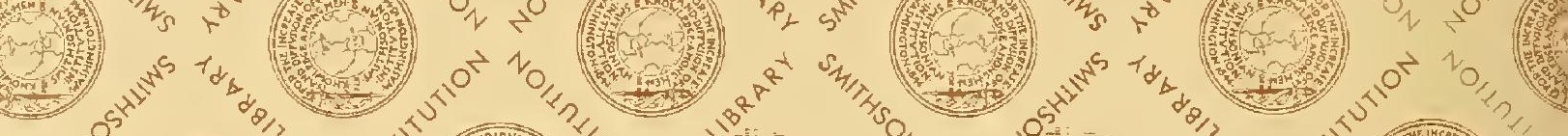

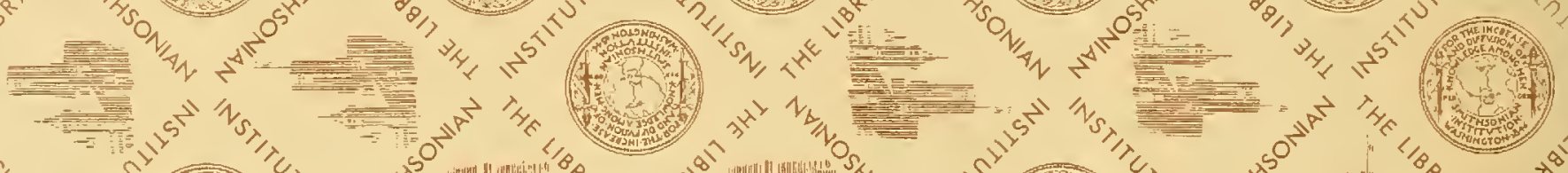

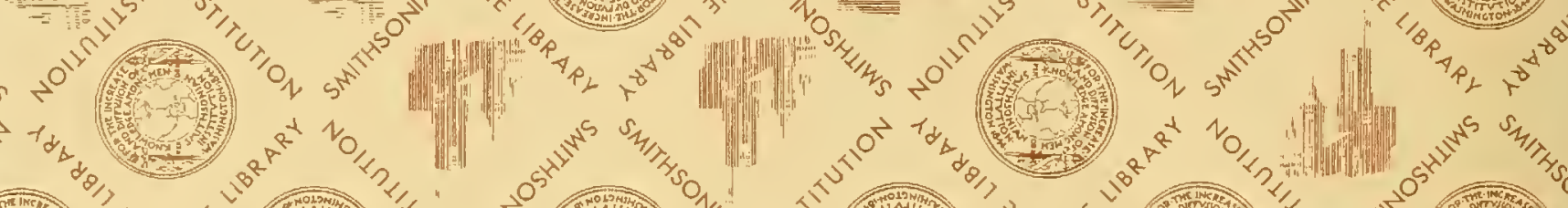
(5)

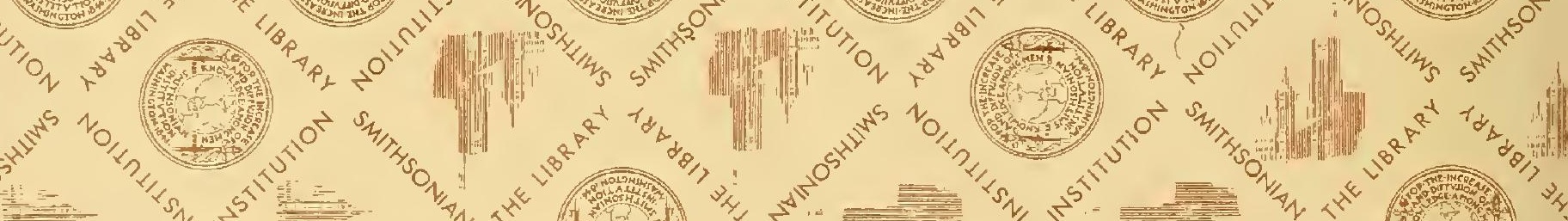
te (65)

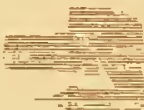

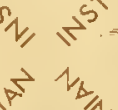
我 $3 x^{2}$

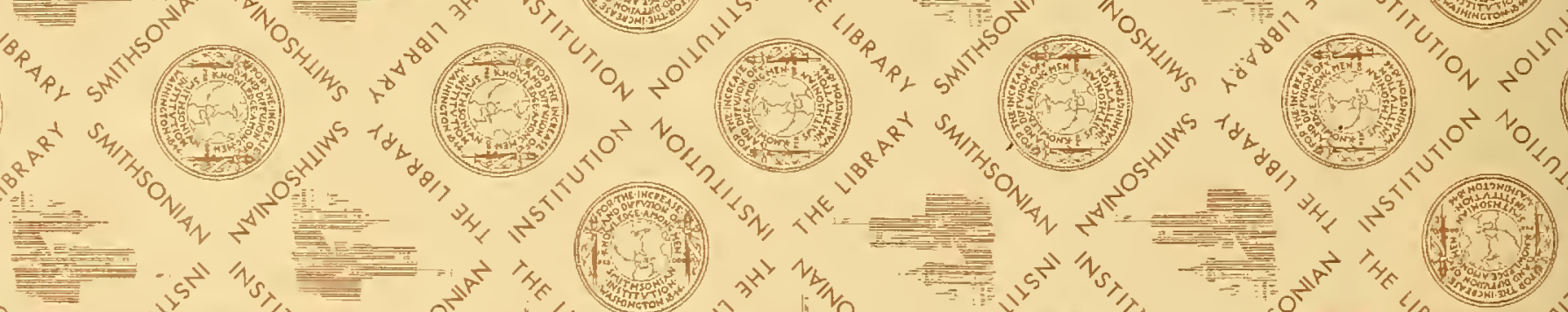

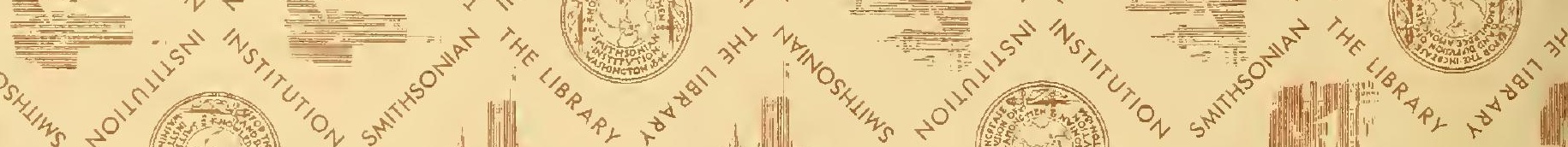
(1)

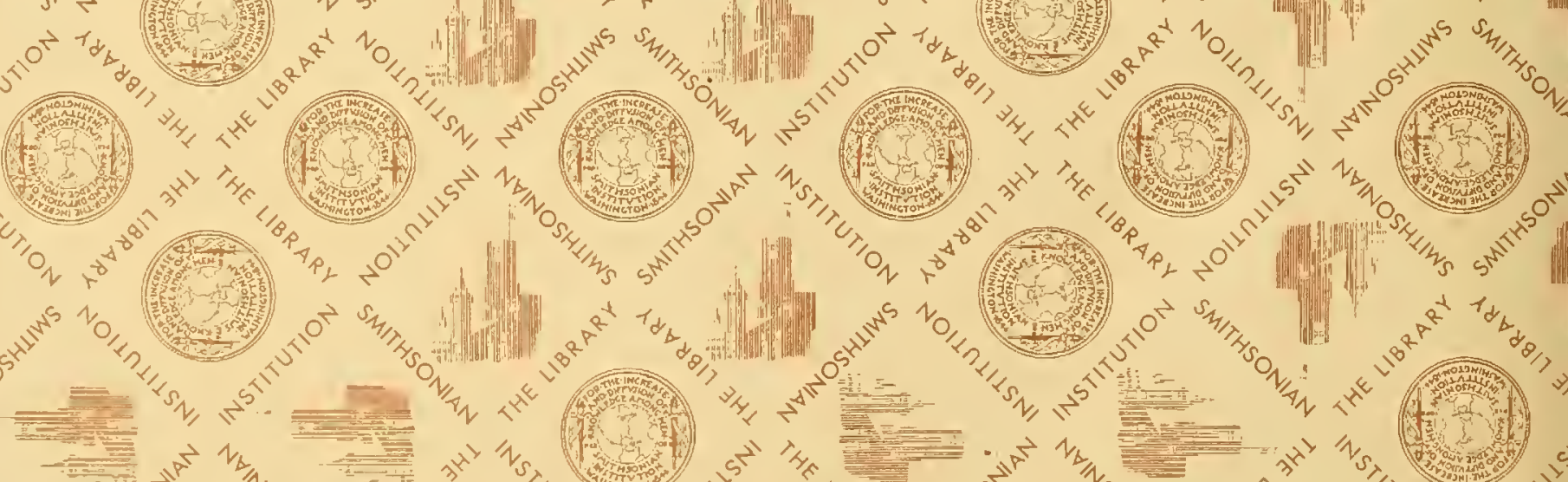
(1) ( Af 7. 
